\title{
Advanced Technology Development Program for Lithium-Ion Batteries: Gen 2 GDR Performance Evaluation Report
}

John P. Christophersen Chinh D. Ho

Gary L. Henriksen

David Howell

July 2006

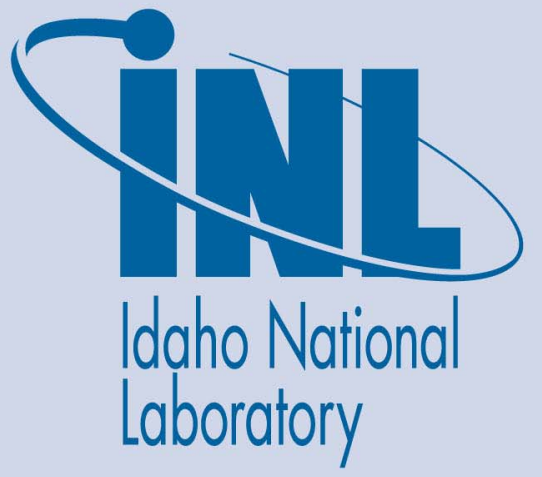

The INL is a U.S. Department of Energy National Laboratory operated by Battelle Energy Alliance 
INL/EXT-06-11488

\title{
Advanced Technology Development Program for Lithium-Ion Batteries: Gen 2 GDR Performance Evaluation Report
}

\author{
Jon P. Christophersen \\ Chinh D. Ho \\ Gary L. Henriksen ${ }^{a}$ \\ David Howell
}

${ }^{\mathrm{a}} \mathrm{ANL}$

${ }^{\mathrm{b}} \mathrm{U} . \mathrm{S}$. DOE

July 2006

Idaho National Laboratory

Idaho Falls, Idaho 83415

Prepared for the

U.S. Department of Energy

Assistant Secretary for Energy Efficiency and Renewable Energy

Under DOE Idaho Operations Office

Contract DE-AC07-05ID14517 


\section{Disclaimer}

This report was prepared as an account of work sponsored by an agency of the United States Government. Neither the United States Government nor any agency thereof, nor any of their employees, makes any warranty, express or implied, or assumes any legal liability or responsibility for the accuracy, completeness, or usefulness of any information, apparatus, product, or process disclosed, or represents that its use would not infringe privately owned rights. References herein to any specific commercial product, process, or service by trade name, trademark, manufacturer, or otherwise does not necessarily constitute or imply its endorsement, recommendation, or favoring by the United States Government or any agency thereof. The views and opinions of authors expressed herein do not necessarily state or reflect those of the United States Government or any agency thereof. 



\section{ABSTRACT}

The United States Department of Energy's Advanced Technology Development Program has completed the performance evaluation of the second generation of lithium-ion cells (i.e., Gen 2 cells). This report documents the testing and analysis of the Gen 2 GDR cells, which were used to debug and assess the newly developed Technology Life Verification Test Manual. The purpose of the manual is to project a 15 -year, 150,000 mile battery life capability with a $90 \%$ confidence interval using predictive models and short-term testing. The GDR cells were divided into two different matrices. The core-life test matrix consisted of calendar- and cycle-life cells with perturbations of the four major acceleration factors (temperature, state-of-charge, throughput, and power rating). The supplemental-life test matrix consisted of cells subjected either to a path dependence study, or a comparison between the standard hybrid pulse power characterization test and the newly-developed minimum pulse power characterization test. Resistance and capacity results are reported. 


\section{EXECUTIVE SUMMARY}

In conjunction with the Partnership for a New Generation of Vehicles, the Advanced Technology Development (ATD) Program was initiated in 1998 by the U.S. Department of Energy's Office of Advanced Automotive Technologies to find solutions to the barriers that limit the commercialization of high-power lithium-ion batteries. In 2002, this partnership was superseded by FreedomCAR (Freedom Cooperative Automotive Research) and this work is now under the auspices of the FreedomCAR and Vehicle Technologies Program. The second generation of lithium-ion cells (i.e., Gen 2 cells) consisted of a baseline chemistry and two variant chemistries (i.e., Variant $\mathrm{C}$ and GDR). This report documents the performance evaluation of the ATD 18650-size Gen 2 GDR cells, which consisted of a change to the baseline negative electrode. The GDR graphite is a round-edge natural graphite that has an amorphous carbon coating at the particle level.

The GDR cells were primarily used to learn and evaluate the new procedures and profiles that have been defined for technology life verification testing. Cell aging consisted of characterization, followed by life testing with periodic breaks for reference performance testing (RPT). Although some cells were subjected to a standard FreedomCAR RPT, which consisted of a $\mathrm{C}_{1} / 1$ discharge followed by a low-current hybrid pulse power characterization (L-HPPC) test, most cells were subjected to the newly-developed minimum pulse power characterization (MPPC) test every four weeks during aging. The MPPC test was designed to provide sufficient information about cell degradation while minimizing the time spent off life testing, and avoiding possible deleterious effects (e.g., full charging and discharging). Although the MPPC does provide impedance degradation at two different states-of-charge (SOCs), there are insufficient data for available power calculations. Consequently, the life degradation models need to be based on resistance or area-specific impedance. However, one significant advantage of the MPPC is the ability to determine the true resistance at the reference temperature (e.g., $30^{\circ} \mathrm{C}$ ) since the MPPC profile is performed at two different temperatures (once at the life-test temperature, and once at $30^{\circ} \mathrm{C}$ ).

The majority of the cells was distributed in a core-life test matrix that consisted of calendar- and cycle-life testing at various temperatures $\left(40,50\right.$, and $\left.60^{\circ} \mathrm{C}\right)$ and two SOCs $(80$ and $40 \%$ SOC). A smaller group of cells was subjected to supplementary testing, in which various assumptions about what did not affect cell degradation were verified. The GDR supplementary matrix consisted of a path dependence study and an RPT study. In the path dependence study, groups of cells were subjected to calendar-life testing, then switched to cycle-life testing after the discharge impedance increase by a specified amount. Other groups of cells started with cycle-life testing, then switched to calendar-life testing. The RPT study group consisted of cycle-life testing at the most benign and most extreme conditions of the core-life test matrix, but with the L-HPPC test instead of the MPPC test every four weeks.

Unfortunately, the GDR cells showed a very large manufacturing variability and inconsistent results. The data indicate that SOC is the most dominant stress factor, with temperature also showing a small effect. Power ratio and throughput did not appear to be significant stress factors. The data also indicated that the MPPC test yields statistically different results from the L-HPPC test, and it does not eliminate some of the deleterious effects it was designed to resolve. Unlike the Gen 2 Baseline and Variant $\mathrm{C}$ cells, the GDR calendarlife cells faded more quickly than the corresponding cycle-life cells (note, however, that the test protocols were different). Both the path dependence and RPT studies were inconclusive. 


\section{ACKNOWLEDGMENTS}

We thank the following people for their technical and programmatic support:

Ira Bloom

Michael R. Anderson

Jim Barnes

Tien Duong

Kevin Gering

Gary Hunt

Chet Motloch

Tim Murphy

Vince Battaglia

Ed Thomas

Harold Haskins
Argonne National Laboratory

DOE-ID

DOE-HQ

DOE-HQ

Idaho National Laboratory

Idaho National Laboratory (consultant)

Idaho National Laboratory (consultant)

Idaho National Laboratory

Lawrence Berkeley National Laboratory

Sandia National Laboratories

USABC (consultant) 


\section{CONTENTS}

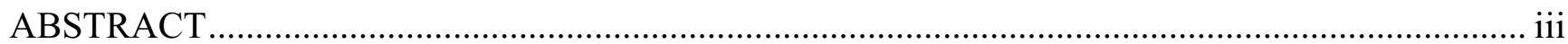

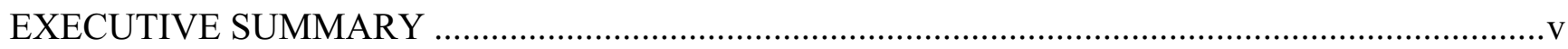

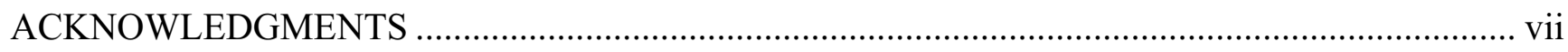

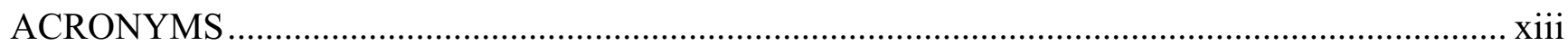

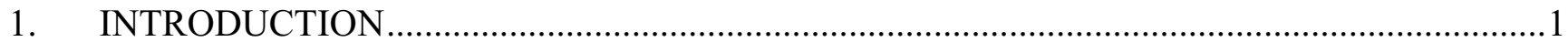

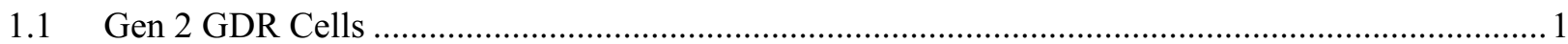

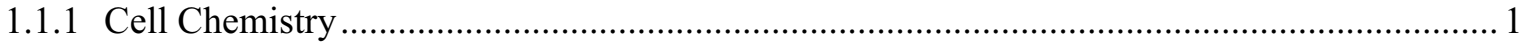

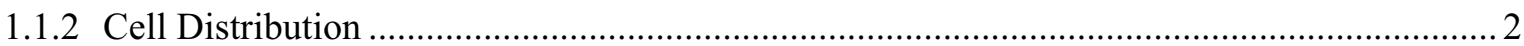

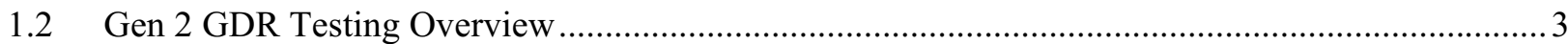

1.2.1 Technology Life Verification Testing ................................................................................... 3

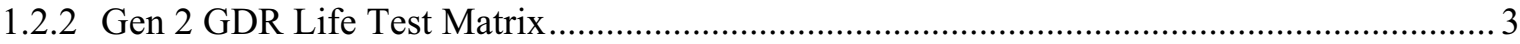

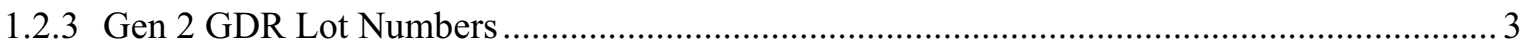

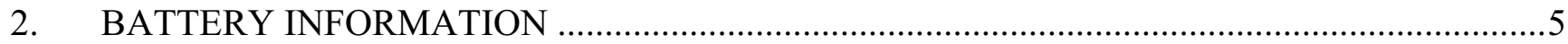

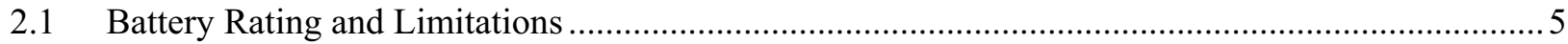

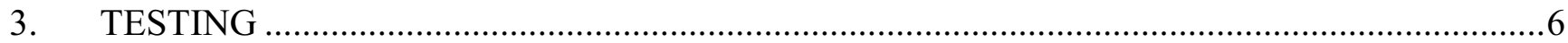

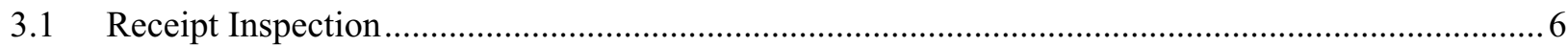

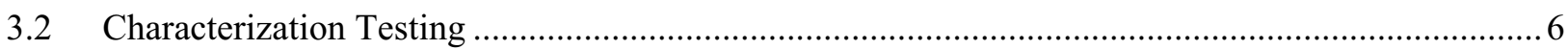

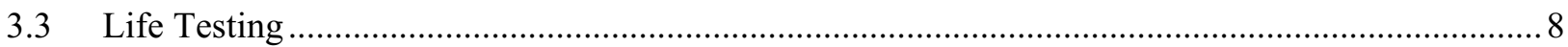

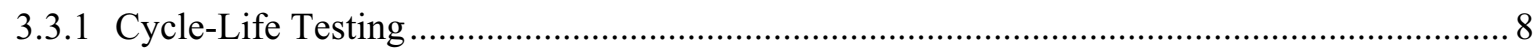

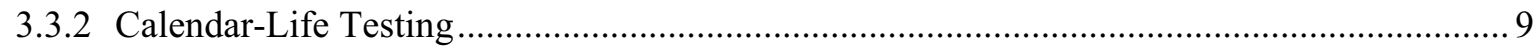

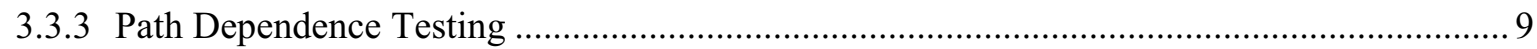

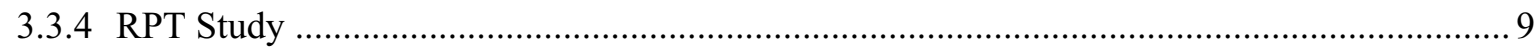

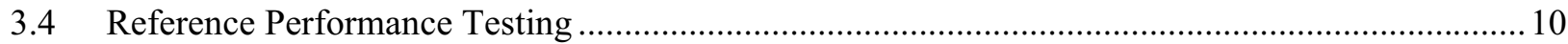

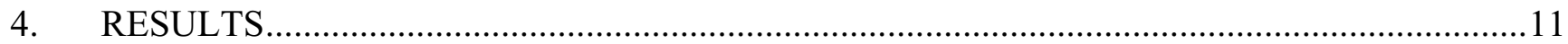

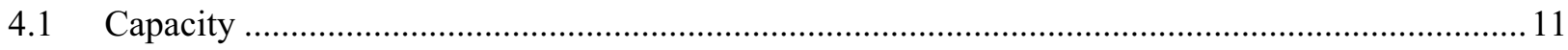

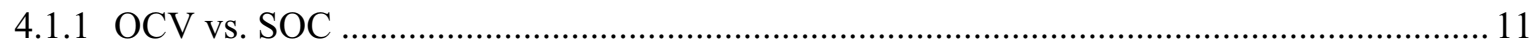

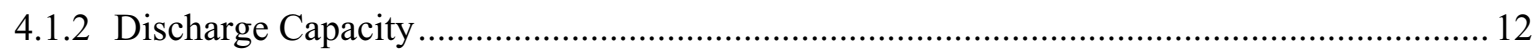

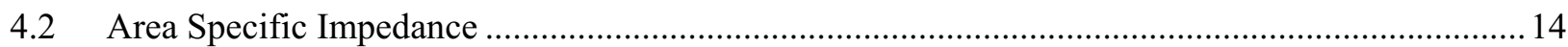

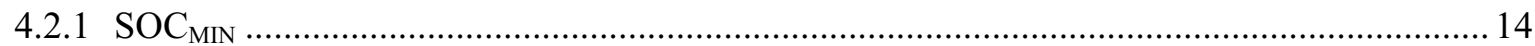

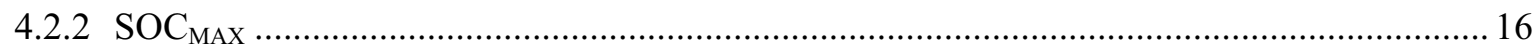

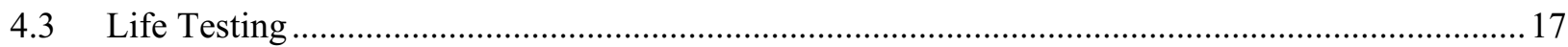

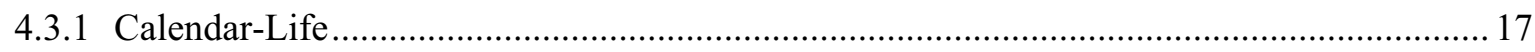

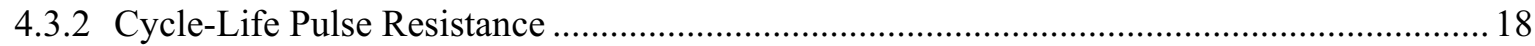




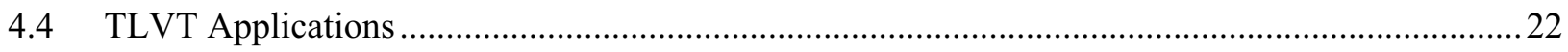

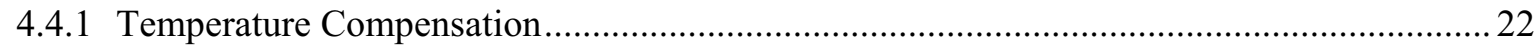

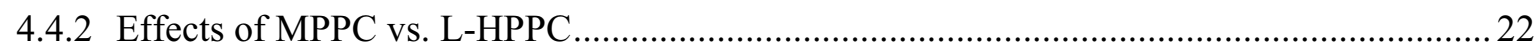

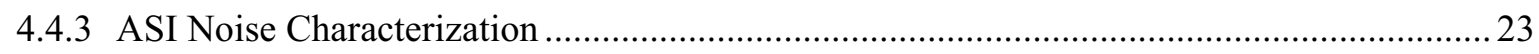

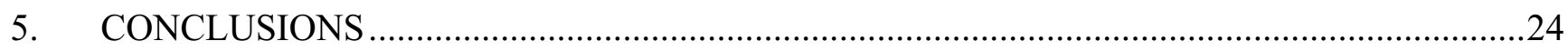

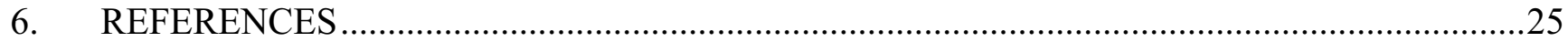

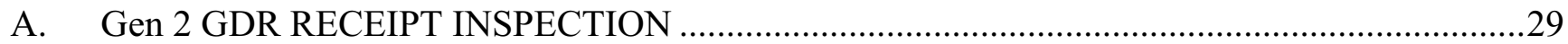

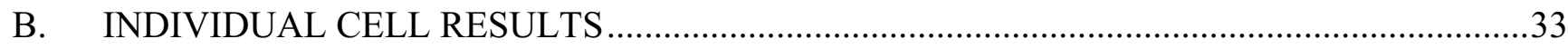

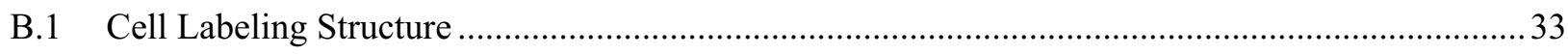

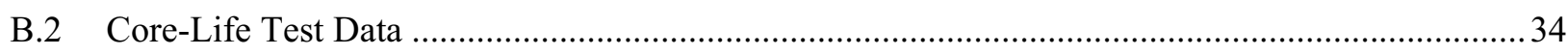

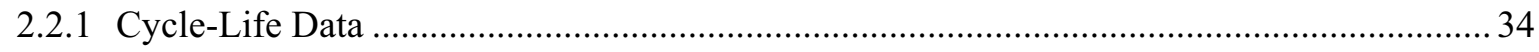

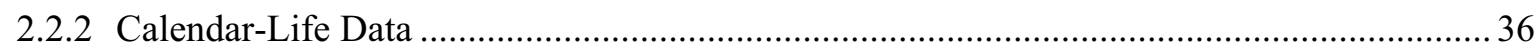

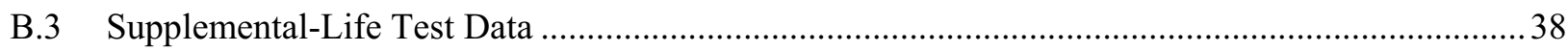

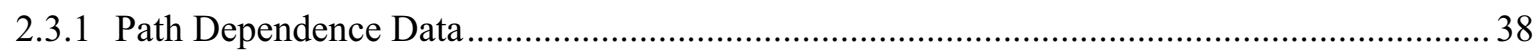

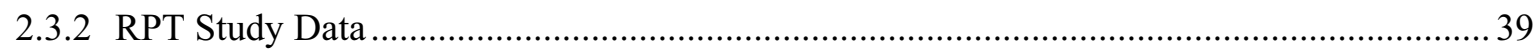

\section{FIGURES}

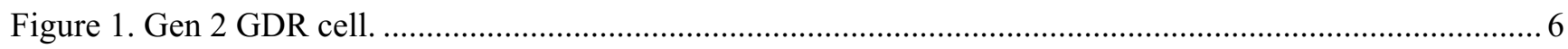

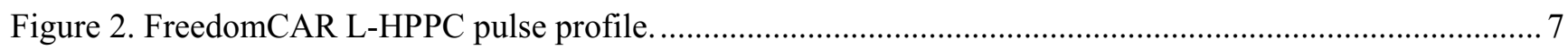

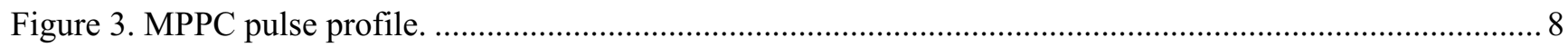

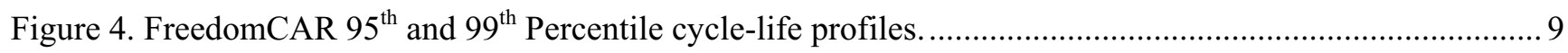

Figure 5. OCV as a function of SOC for a representative GDR cell. ........................................................... 12

Figure 6. Average $C_{1} / 1$ static capacity for each TLVT core-life matrix group................................................ 13

Figure 7. Average $C_{1} / 1$ static capacity for each TLVT supplemental matrix group ........................................ 14

Figure 8. Average discharge ASI at $\mathrm{SOC}_{\mathrm{MIN}}$ for each TLVT core-life matrix group....................................... 15

Figure 9. Average discharge ASI at $\mathrm{SOC}_{\mathrm{MIN}}$ for each TLVT supplemental matrix group............................... 15

Figure 10. Average discharge ASI at $\mathrm{SOC}_{\mathrm{MAX}}$ for each TLVT core-life matrix group.................................... 16

Figure 11. Average discharge ASI at $\mathrm{SOC}_{\mathrm{MAX}}$ for each TLVT supplemental matrix group............................ 17

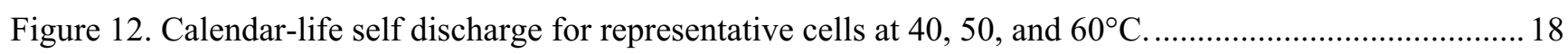

Figure 13. Cycle-life pulse resistance for a representative cell at the 40540 condition.................................... 19

Figure 14. Cycle-life pulse resistance for a representative cell at the 40950 condition....................................20

Figure 15. Cycle-life pulse resistance for a representative cell at the 80540 condition....................................20

Figure 16. Cycle-life pulse resistance for a representative cell at the 80950 condition....................................2 21

Figure 17. Comparison of pulse discontinuity between Gen 2 Baseline and GDR cells..................................2 21 
Figure 18. Effect of temperature compensation on the GDR cells (e.g., 80950 at $\left.\mathrm{SOC}_{\mathrm{MIN}}\right)$...........................22

Figure 19. Difference between HPPC and MPPC ASIs at $\mathrm{SOC}_{\mathrm{MAX}}$ and $\mathrm{SOC}_{\mathrm{MIN}}$ for the cycle-life cells............ 23

\section{TABLES}

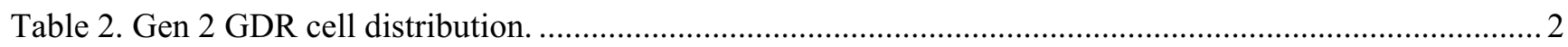

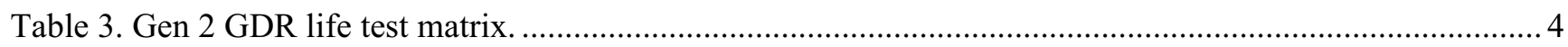

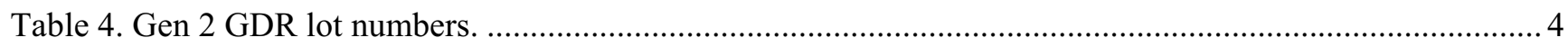

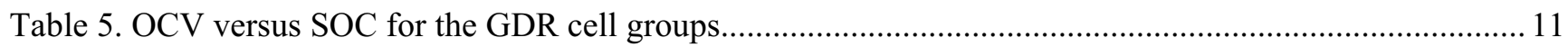

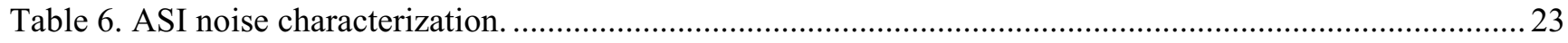

Table A.1. Gen 2 GDR cell receipt inspection for core-life cells. ............................................................29

Table A.2. Gen 2 GDR cell receipt inspection for supplemental-life cells.................................................... 30

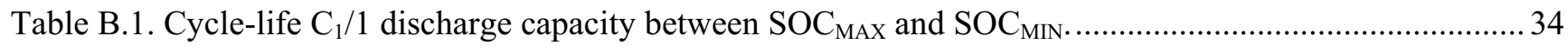

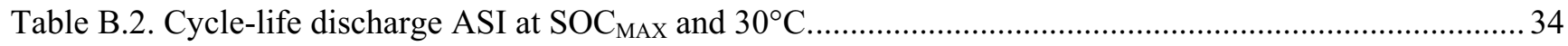

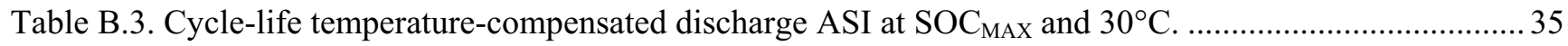

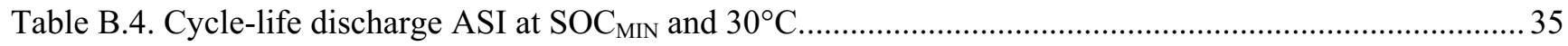

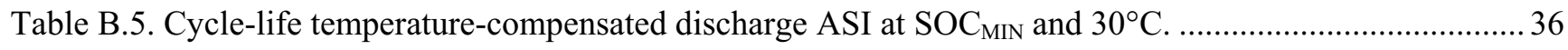

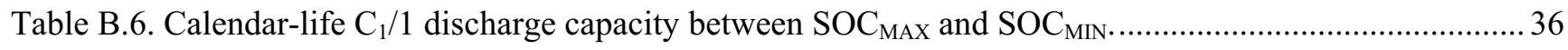

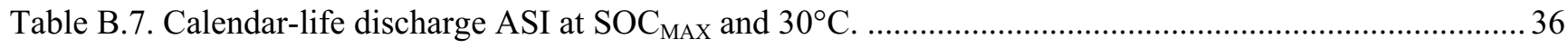

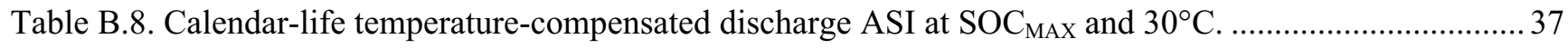

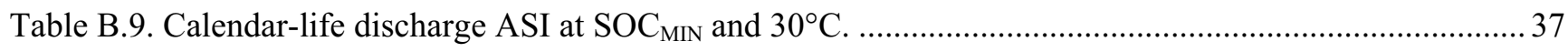

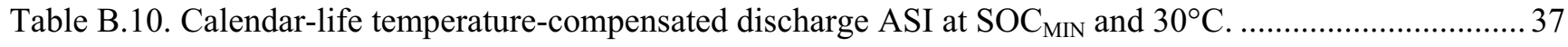

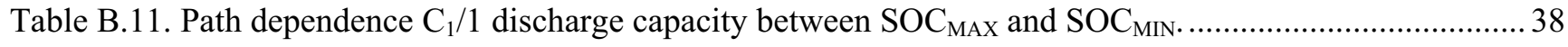

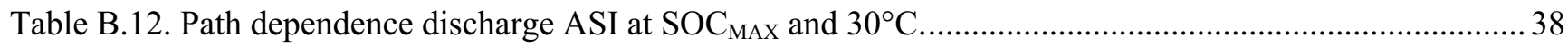

Table B.13. Path dependence temperature-compensated discharge ASI at $\mathrm{SOC}_{\mathrm{MAX}}$ and $30^{\circ} \mathrm{C} \ldots \ldots \ldots \ldots \ldots \ldots \ldots . . . . . . . . . .38$

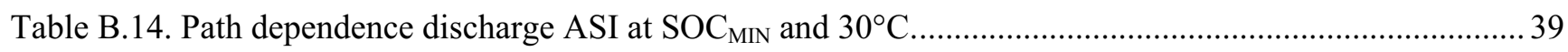

Table B.15. Path dependence temperature-compensated discharge ASI at $\mathrm{SOC}_{\mathrm{MIN}}$ and $30^{\circ} \mathrm{C} \ldots \ldots \ldots \ldots \ldots \ldots \ldots . . . . . . . . . . . .39$

Table B.16. RPT study $\mathrm{C}_{1} / 1$ discharge capacity between full charge and discharge......................................... 39

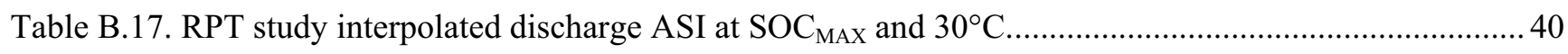

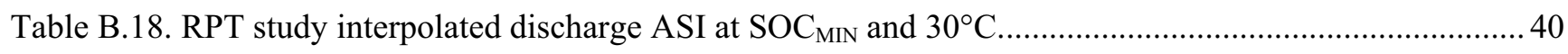

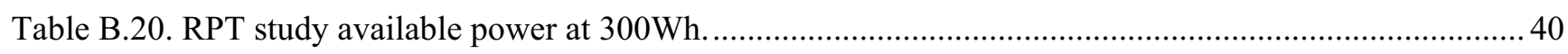




\section{ACRONYMS}

ANL Argonne National Laboratory

ASI area-specific impedance

ATD Advanced Technology Development

BOL beginning-of-life

DOD depth-of-discharge

FreedomCAR Freedom Cooperative Automotive Research

Gen Generation

INL Idaho National Laboratory

L-HPPC low-current hybrid pulse power characterization

LBNL Lawrence Berkeley National Laboratory

MPPC minimum pulse power capability

OCV open-circuit voltage

OSPS operating set point stability

RPT reference performance test

SOC state-of-charge

SNL Sandia National Laboratories

TLVT Technology Life Verification Test

VEC vinyl ethylene carbonate 


\section{Advanced Technology Development Program for Lithium-Ion Batteries:}

\section{Gen 2 GDR Performance Evaluation Report}

\section{INTRODUCTION}

In conjunction with the Partnership for a New Generation of Vehicles, the U.S. Department of Energy initiated the Advanced Technology Development (ATD) Program in 1998 to address the technical barriers impeding the commercialization of high-power lithium-ion batteries for hybrid electric vehicle applications. These barriers include insufficient calendar life, high production costs, poor response to abuse scenarios, and poor low temperature performance. In 2002, the Partnership for a New Generation of Vehicles was superceded by FreedomCAR (Freedom Cooperative Automotive Research), and this work is now sponsored by the FreedomCAR and Vehicle Technologies Program. A full description of the ATD Program within the context of the overall FreedomCAR energy storage research and development is provided in Reference 1.

Five DOE National Laboratories are participating in the ATD Program. Argonne National Laboratory (ANL) has overall programmatic and technical lead responsibilities, including cell chemistry. The Idaho National Laboratory (INL) has lead responsibility for cell testing and aging, in collaboration with ANL and Sandia National Laboratories (SNL). SNL has lead responsibility for the investigation of abuse tolerance. Lawrence Berkeley National Laboratory (LBNL) is the lead diagnostic laboratory, in collaboration with Brookhaven National Laboratory, ANL, SNL, and INL. These five National Laboratories are working in close coordination to develop a fundamental understanding of life degradation mechanisms and an accurate life prediction methodology; identify and mitigate factors limiting abuse tolerance; identify low cost materials, components, and technologies; and identify and mitigate factors that contribute to poor performance at low temperatures.

\subsection{Gen 2 GDR Cells}

\subsubsection{Cell Chemistry}

The second generation of ATD lithium-ion cells (i.e., Gen 2 cells) included a baseline chemistry and two variants. The first variant chemistry (Variant $\mathrm{C}$ ) consisted of a change to the composition of the positive electrode. Test results and analysis from the Gen 2 Baseline and Variant $\mathrm{C}$ cells are discussed in a separate report (Reference 2). The GDR cell chemistry is defined in Reference 3 and summarized in Table 1. These 18650-size cells were manufactured by Quallion, LLC to ANL specifications. The majority of these cells were manufactured with the same Gen 2 baseline chemistry, but with a "GDR" graphite instead of a MAG-10 graphite for the negative electrode. The GDR graphite is a round-edge natural graphite that has an amorphous carbon coating at the particle level. Potential advantages over the MAG-10 include enhanced safety (due to the rounded edges) and relatively low cost. Some of the GDR cells also included a $2 \mathrm{wt} \%$ vinyl ethylene carbonate (VEC) electrolyte additive, and test results for these cells are discussed in Reference 2. It should also be noted that the electrodes for these cells were left in a glove box, unsealed, for 8 to 9 months prior to assembly, which may have contributed to the wide performance variability and rapid degradation. 
Table 1. Gen 2 GDR cell chemistry.

\begin{tabular}{ll}
\hline \hline & \multicolumn{1}{c}{ Gen 2 GDR Cells } \\
\hline \hline & $8 \mathrm{wt} \%$ PVDF binder \\
& $4 \mathrm{wt} \%$ SFG-6 graphite \\
Positive Electrode & $4 \mathrm{wt} \%$ carbon black \\
& $84 \mathrm{wt} \% \mathrm{LiNi}_{0.8} \mathrm{Co}_{0.15} \mathrm{Al}_{0.5} \mathrm{O}_{2}$ \\
& \\
& $10 \mathrm{wt} \% \mathrm{PVDF}$ binder \\
Negative Electrode & $90 \mathrm{wt} \% \mathrm{GDR}_{\text {graphite }}$ \\
& $1.2 \mathrm{M} \mathrm{LiPF}{ }_{6}$ in EC:EMC (3:7 wt\%) \\
Electrolyte & \\
Separator & $25 \mu \mathrm{m}$ thick PE (Celgard) \\
\hline \hline
\end{tabular}

\subsubsection{Cell Distribution}

Quallion manufactured a total of 54 Gen 2 GDR cells for testing and diagnostics. The cell distribution is shown in Table 2. Of the 37 cells designated for life testing at INL, 34 were allocated for studies related to technology life verification testing, and are discussed in this report. Life testing and analyses for these cells were performed in accordance with the procedures outlined in the Battery Technology Life Verification Test Manual (Reference 4), and as detailed in the cell-specific test plan (Reference 5). The cells were tested against the FreedomCAR Minimum Power Assist goals (Reference 6). The other three INL cells were designated for low temperature performance testing, but a test matrix was never developed due to early cell failures. The six ANL life test cells were tested the same way as the Gen 2 Baseline and Variant $C$ cells, and are discussed in Reference 2. Details concerning the other GDR cells (i.e., cells designated for diagnostic or thermal abuse testing) are not discussed in this report.

Table 2. Gen 2 GDR cell distribution.

\begin{tabular}{|c|c|c|c|c|}
\hline & Life Testing & Diagnostics & Thermal Abuse & Archive \\
\hline INL & 37 GDR Cells & & & \\
\hline \multirow{2}{*}{ ANL } & 3 GDR Cells & 1 GDR Cell & & 4 GDR Cells \\
\hline & 3 GDR Cells with VEC & 1 GDR Cell with VEC & & \\
\hline SNL & & & 3 GDR Cells & \\
\hline \multirow{2}{*}{ LBNL } & & 1 GDR Cell & & \\
\hline & & 1 GDR Cell with VEC & & \\
\hline
\end{tabular}




\subsection{Gen 2 GDR Testing Overview}

\subsubsection{Technology Life Verification Testing}

The purpose of Gen 2 GDR life testing was primarily to help refine various aspects of the Technology Life Verification Test (TLVT) Manual (Reference 4). The goal of TLVT is to verify the 15year, 150,000 mile FreedomCAR battery life capability at the target confidence level of $90 \%$ within one or two years of life testing. The TLVT methodology assumes small measurement-to-measurement errors and cell-to-cell manufacturing differences, and are based on Monte Carlo simulations and the bootstrap method (Reference 7). Although a chemistry-specific mechanistic model is recommended for life predictions, a default empirical model has been provided in the manual based on the ATD Gen 2 Baseline and Variant $\mathrm{C}$ life data (References 2 and 4). Life testing consists of a complete full factorial core matrix that takes into account known degradation mechanisms. The example core life test matrix provides adequate coverage of four major stress factors (temperature, SOC, energy throughput, and pulse power rating). The supplemental life test matrix confirms assumptions made when developing the core life test matrix (e.g., path independence).

\subsubsection{Gen 2 GDR Life Test Matrix}

The Gen 2 GDR TLVT life test matrix is shown in Table 3. Twenty-two cells were used for core life testing (16 cycle-life and 6 calendar-life). Temperature was the only varying stress factor for calendarlife testing. The cycle-life cell matrix consisted of different temperatures, states of charge (SOCs), throughput rates, and pulse power ratings (in accordance with the example acceleration factors in the TLVT Manual). The throughput and pulse power ratings are based on the pulse profile used during cycling (Section 3.3.1).

Twelve cells were assigned to a supplemental life test matrix. Eight of these cells were used to for a path dependence study by switching from calendar- to cycle-life and vice versa. The other four cells were used to study the impact of the newly-developed reference performance test (RPT) for TLVT testing versus the standard FreedomCAR reference performance test (Section 3.2).

\subsubsection{Gen 2 GDR Lot Numbers}

The Gen 2 GDR cells were manufactured in four different lots over a period of four months. The number of cells per lot for all GDR cells is shown in Table 4. The cells tested under the matrix shown in Table 3, along with the date received, are also shown in Table 4. Twenty-nine GDR cells were received by INL on February 25, 2004. Initial testing was started on April 6, 2004 using 16 cells from Lot F03E916 for the cycle-life testing, four cells each from Lots F03E916 and F04A914 for the path dependence group, and four cells from Lot F04A908 for the RPT study. The remaining cell from Lot F04A914 was placed in cold storage for future low temperature performance testing. After initial characterization testing, cell pairs were assigned to the test matrix based on matching powers (this involved moving cells to different thermal blocks and temperature chambers). Due to poor performance, all testing was stopped on May 24, 2004. Four cells (two each from Lots F04A914 and F04A908) showed more than $26 \%$ power fade after only 600 cycles. These four cells were removed from test and shipped back to Quallion for diagnostic analysis on June 22, 2004.

Another eight cells from Lot F04D151 arrived on May 5, 2004. Six of these cells were assigned to the calendar-life test matrix, and two were used as replacements for the path dependence study. An archived cell (see Table 2) from Lot F04D151 was also received from ANL on June 21, 2004. This cell and the INL cell in cold storage were used as replacement cells for the RPT study. Testing was reinitiated on June 4, 2004, but cells were not re-matched according to power performance. The cycle-life cells reached end-of-test on May 11,2005. The calendar-life and supplemental life test cells reached endof-test by March 15, 2005. 
Table 3. Gen 2 GDR life test matrix.

\begin{tabular}{|c|c|c|c|c|c|c|}
\hline & & $\begin{array}{l}\# \text { of } \\
\text { Cells }\end{array}$ & $\begin{array}{c}\text { Temperature } \\
\left({ }^{\circ} \mathrm{C}\right)\end{array}$ & $\begin{array}{l}\text { SOC } \\
(\%)\end{array}$ & $\begin{array}{l}\text { Throughput } \\
\text { (mph) }\end{array}$ & $\begin{array}{c}\text { Power Ratio } \\
(\%)\end{array}$ \\
\hline \multirow{11}{*}{ ப் } & Cycle-Life 1 & 2 & 40 & 40 & $20 \mathrm{mph}$ & $80 \%$ \\
\hline & Cycle-Life 2 & 2 & 40 & 40 & $25 \mathrm{mph}$ & $96 \%$ \\
\hline & Cycle-Life 3 & 2 & 40 & 80 & $20 \mathrm{mph}$ & $80 \%$ \\
\hline & Cycle-Life 4 & 2 & 40 & 80 & $25 \mathrm{mph}$ & $96 \%$ \\
\hline & Cycle-Life 5 & 2 & 50 & 40 & $20 \mathrm{mph}$ & $80 \%$ \\
\hline & Cycle-Life 6 & 2 & 50 & 40 & $25 \mathrm{mph}$ & $96 \%$ \\
\hline & Cycle-Life 7 & 2 & 50 & 80 & $20 \mathrm{mph}$ & $80 \%$ \\
\hline & Cycle-Life 8 & 2 & 50 & 80 & $25 \mathrm{mph}$ & $96 \%$ \\
\hline & Calendar-Life 1 & 2 & 40 & 80 & Standby & $0 \%$ \\
\hline & Calendar-Life 2 & 2 & 50 & 80 & Standby & $0 \%$ \\
\hline & Calendar-Life 3 & 2 & 60 & 80 & Standby & $0 \%$ \\
\hline \multirow{6}{*}{ 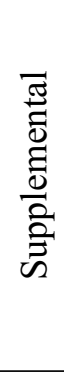 } & Path Dependence 1 & 2 & 40 & 40 & Standby / $20 \mathrm{mph}$ & $0 \% / 80 \%$ \\
\hline & Path Dependence 2 & 2 & 40 & 40 & $20 \mathrm{mph} /$ Standby & $80 \% / 0 \%$ \\
\hline & Path Dependence 3 & 2 & 50 & 80 & Standby / $25 \mathrm{mph}$ & $0 \% / 96 \%$ \\
\hline & Path Dependence 4 & 2 & 50 & 80 & $25 \mathrm{mph} / \mathrm{Standby}$ & $96 \% / 0 \%$ \\
\hline & RPT Study 1 & 2 & 40 & 40 & $20 \mathrm{mph}$ & $80 \%$ \\
\hline & RPT Study 2 & 2 & 50 & 80 & $25 \mathrm{mph}$ & $96 \%$ \\
\hline
\end{tabular}

Table 4. Gen 2 GDR lot numbers.

\begin{tabular}{cccc}
\hline \hline Lot Number & Total Number of Cells & Number of INL Cells & Date Received \\
\hline \hline F03E916 & 24 & 20 & $2-25-04$ \\
F04A914 & 5 & 5 & $2-25-04$ \\
F04A908 & 4 & 4 & $2-25-04$ \\
F04D151 & 16 GDR-Only Cells & $8 / 1$ & $5-05-04 / 6-21-04$ \\
\hline \hline
\end{tabular}




\section{BATTERY INFORMATION \\ 2.1 Battery Rating and Limitations}

The following battery ratings and limitations were used for testing and analyses:

$\mathrm{C}_{1} / 1$ rated capacity

$\mathrm{C}_{1} / 1$ nominal capacity (average)

Cell nominal weight (average)

Electrode Area

Battery size factor:

Cycle-Life

Calendar-Life

Path Dependence

RPT Study

Temperature

Operating Range

Storage

Maximum (discharge)

Maximum (charge)

Voltage Limits

Minimum discharge voltage

Maximum charge voltage

HPPC Calculation voltages

Maximum

Minimum

Current Limits

Maximum discharge current

Maximum charge current $\underline{\text { GDR Cells }}$

$0.9 \mathrm{~A} \cdot \mathrm{h}$

$0.906 \mathrm{~A} \cdot \mathrm{h}$

$38.6 \mathrm{~g}$

$810.7 \mathrm{~cm}^{2}$

459

471

476

488

-20 to $+60^{\circ} \mathrm{C}$ (discharge)

$10^{\circ} \mathrm{C} \pm 3{ }^{\circ} \mathrm{C}$

$60^{\circ} \mathrm{C}$

$40^{\circ} \mathrm{C}$

$3.0 \mathrm{~V}$ (10-s pulse)

$3.0 \mathrm{~V}$ (continuous)

$4.3 \mathrm{~V}$ (10-s pulse)

$4.1 \mathrm{~V}$ (continuous)

$4.1 \mathrm{~V}$

$3.0 \mathrm{~V}$

7.2 A (10-s pulse)

$1.8 \mathrm{~A}$ (continuous)

7.2 A (10-s pulse)

0.9 A (continuous) 


\section{TESTING}

Characterization and life testing were performed in accordance with the FreedomCAR Battery Test Manual (Reference 6), the Battery Technology Life Verification Test Manual (Reference 4), and the Gen 2 GDR test plan (References 5). FreedomCAR performance goals, procedures, analytical methodologies, and ATD specific testing requirements are detailed in these documents and are summarized below.

\subsection{Receipt Inspection}

A receipt inspection of all cells was performed prior to testing to verify that there was no damage during shipping. This includes a visual inspection and measuring cell weights, open-circuit voltages $(\mathrm{OCV})$ and impedance at $1 \mathrm{kHz}$. This inspection showed that the cells were not physically damaged, with no signs of leaking or shorting. The average cell weight was $38.6 \pm 0.3 \mathrm{~g}$. The average beginning of life (BOL) real impedance at $1 \mathrm{kHz}$ was $10.9 \pm 0.7 \mathrm{~m} \Omega$ at an average OCV of $3.68 \pm 0.02 \mathrm{~V}$ (roughly $50 \%$ SOC). Receipt inspection data for each cell is shown in Appendix A. Figure 1 shows a Gen 2 GDR cell pictured during the receipt inspection.

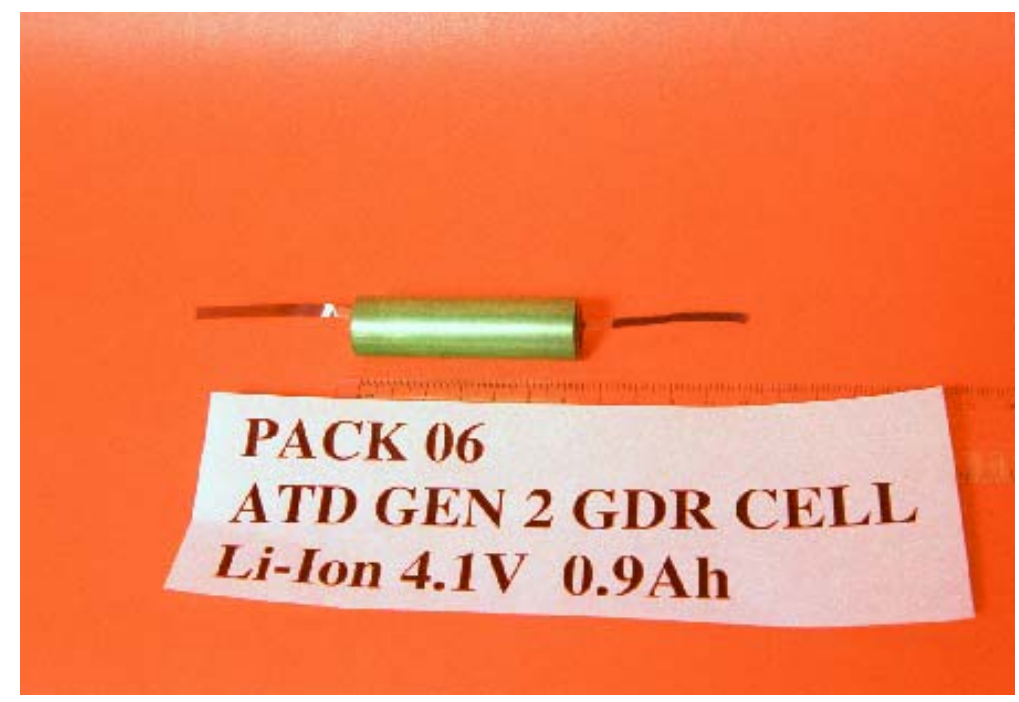

Figure 1. Gen 2 GDR cell.

\subsection{Characterization Testing}

Following the receipt inspection, characterization testing was performed on all cells prior to aging to establish BOL performance parameters, including capacity, resistance, power, and energy. All characterization testing was performed at $30^{\circ} \mathrm{C}$, and was initiated with three consecutive discharges at the $\mathrm{C}_{1} / 1$ rate. This test consists of a constant current discharge to the minimum voltage from a fully charged state using the rated capacity defined at the 1 -h rate (i.e., subscript " 1 "). For example, the $\mathrm{C}_{1} / 1$ discharge test is performed at $0.9 \mathrm{Ah} / 1 \mathrm{~h}$, or $0.9 \mathrm{~A}$.

The low-current hybrid pulse power characterization (L-HPPC) test was performed next. The test profile is shown in Figure 2 and defined in Reference 6. It consists of 10-s constant-current discharge and regen pulses with a 40-s rest period in between, for a total duration of $60 \mathrm{~s}$. The discharge pulse is performed at a $5 \mathrm{C}_{1}$ rate (i.e., $4.5 \mathrm{~A}$ for the GDR cells). The regen pulse is performed at $75 \%$ of the discharge rate (i.e., $3.375 \mathrm{~A}$ ). This profile is repeated at every $10 \%$ depth-of-discharge (DOD) increment, with a 1-h rest at OCV at each DOD increment to ensure that the cells have electrochemically and thermally equilibrated (Reference 6). 


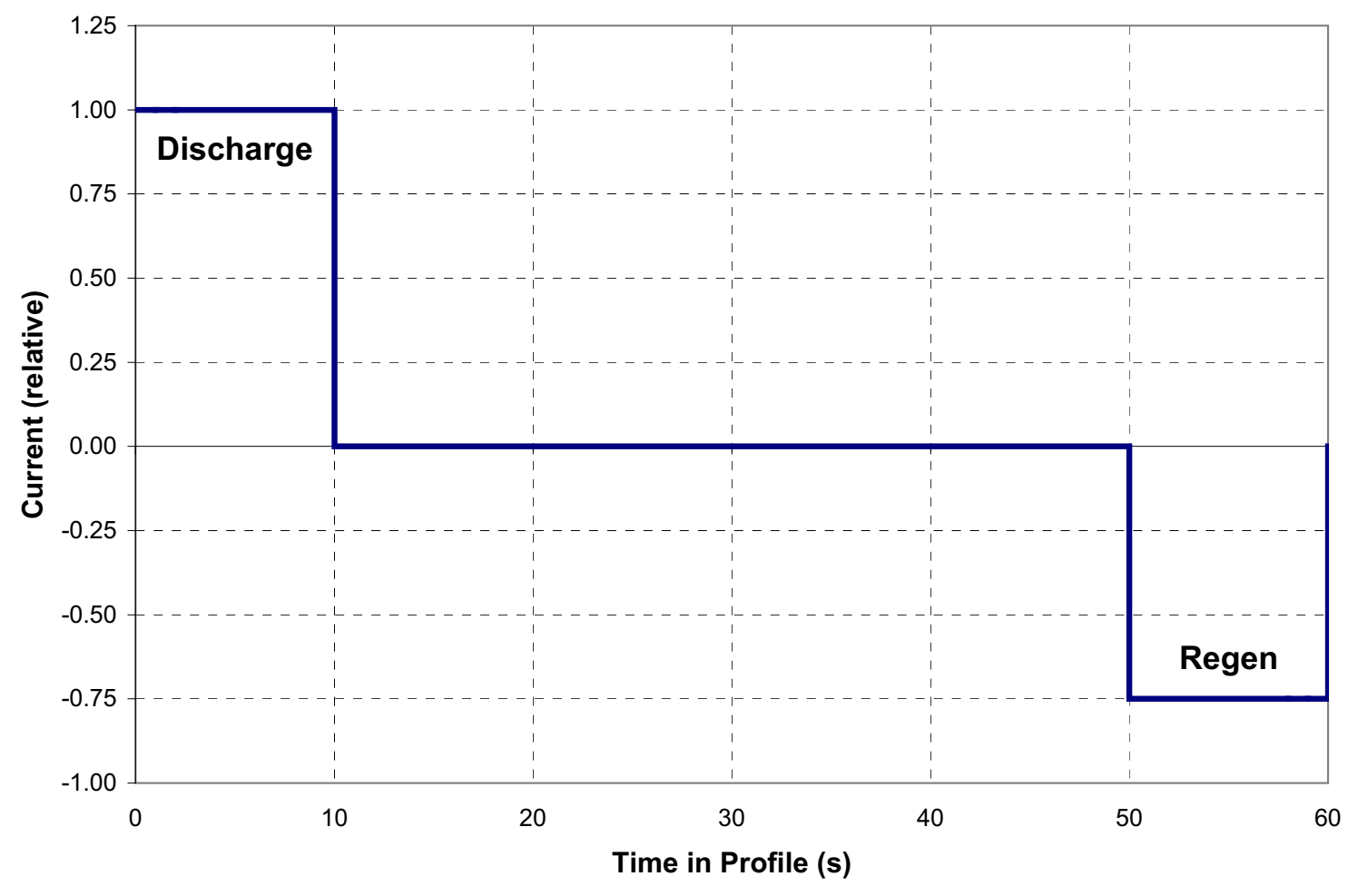

Figure 2. FreedomCAR L-HPPC pulse profile.

Following the L-HPPC test, the OCV was determined as a function of SOC using a newly designed test from the TLVT Manual (Reference 4). Beginning from a fully charged state, the cell is discharged at $\mathrm{a} \mathrm{C}_{1} / 1$ rate in $5 \%$ DOD increments of the rated capacity (i.e., $0.045 \mathrm{Ah}$ ) followed by a one-hour rest at $\mathrm{OCV}$ to determine the equilibrium voltage. This sequence is repeated until the minimum voltage of $3.0 \mathrm{~V}$ is reached.

For most cells (other than the RPT study group), the next characterization test was the newly designed minimum pulse power characterization (MPPC) test as defined in Reference 4 and shown in Figure 3. The purpose of the MPPC is to minimize the irrelevant stresses induced by the full $\mathrm{C}_{1} / 1$ and LHPPC test, such as the time spent at full charge (Reference 8). The MPPC consists of only two L-HPPC pulse profiles (Figure 2), with a $\mathrm{C}_{1} / 1$ taper discharge in between. These pulse profiles are performed at two SOC conditions known as $\mathrm{SOC}_{\mathrm{MAX}}$ and $\mathrm{SOC}_{\mathrm{MIN}}$, which are reference conditions representing the anticipated standard operating range for a battery system (typically specified but the manufacturer). The GDR cell SOC range was 80 and 40\% SOC, respectively. One significant advantage of the MPPC is that it is performed at both life-test temperature and reference temperature (i.e., $30^{\circ} \mathrm{C}$ ), allowing life predictions to be based on temperature-compensated data. A disadvantage of the MPPC is the inability to acquire accurate power data at the target FreedomCAR goal of $300 \mathrm{Wh}$ due to having performance data at only two SOCs. All TLVT life predictions are based on resistance or the area-specific impedance. The area-specific impedance (ASI) is the cell resistance scaled by the electrode area $\left(810.7 \mathrm{~cm}^{2}\right.$ for the GDR cells). 


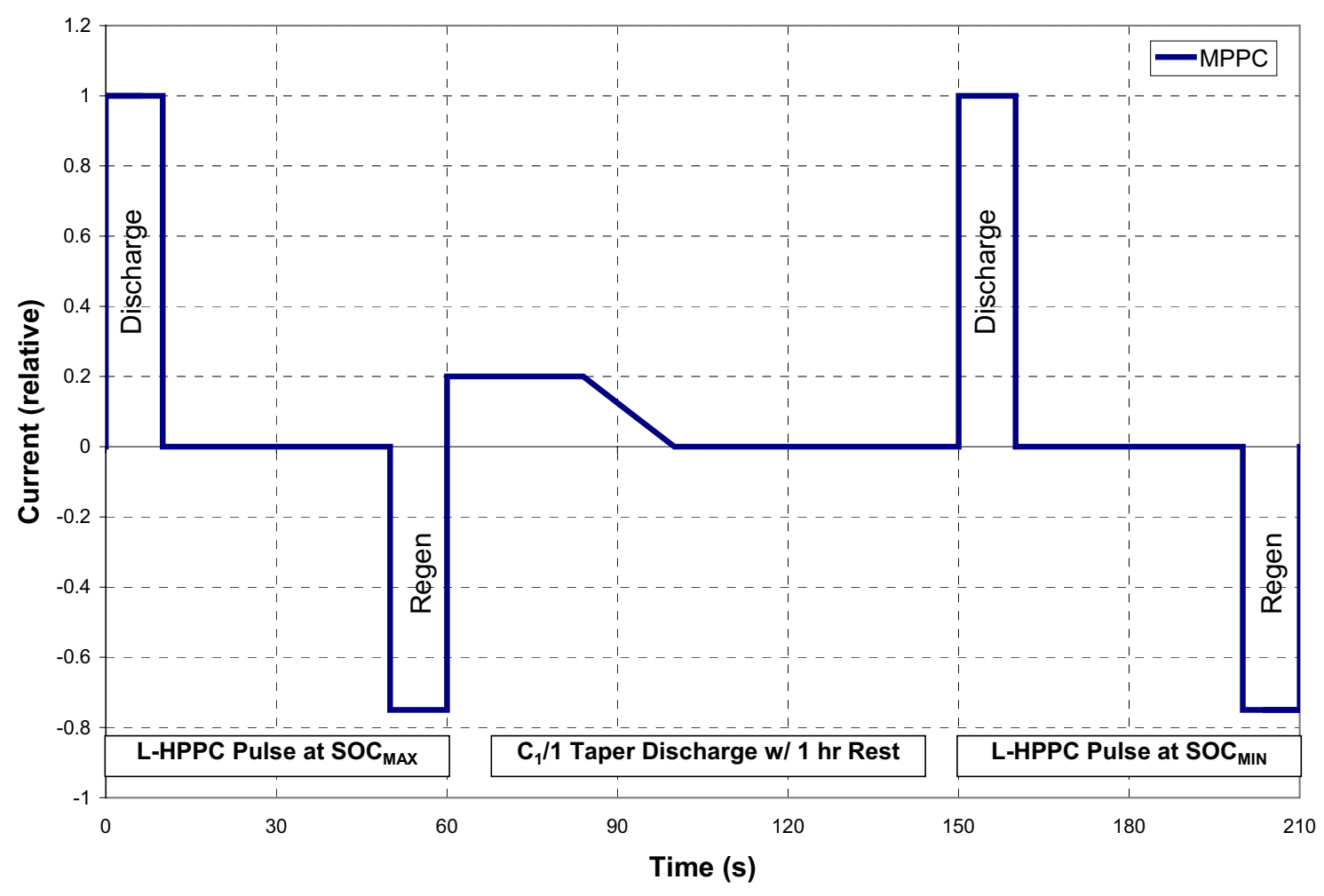

Figure 3. MPPC pulse profile.

\subsection{Life Testing}

\subsubsection{Cycle-Life Testing}

Cycle-life testing is based on the FreedomCAR minimum power assist $95^{\text {th }}$ and $99^{\text {th }}$ Percentile profiles, as defined in Reference 6 and shown in Figure 4. It consists of constant power discharge and regen pulses for a total duration of $90 \mathrm{~s}$. These profiles are repeated continuously during the cycle-life test while centered around the specified SOC in Table 3 ( 80 or $40 \%$ SOC). The $95^{\text {th }}$ Percentile profile has a power ratio of $80 \%$ (see Table 3) since the "Launch" pulse is a $20 \mathrm{~kW}$ pulse $(80 \%$ of the discharge power goal of $25 \mathrm{~kW}$ ). Similarly, the $99^{\text {th }}$ Percentile profile has a $96 \%$ power ratio with a "Launch" pulse of $24 \mathrm{~kW}$. These constant power profiles are for a full-size battery pack and need to be scaled to cell-size levels using the battery size factor, which is defined in Reference 6. These profiles are also designed for an energy swing of $25 \mathrm{Wh}$ with an assumed energy throughput that corresponds to $20 \mathrm{mph}$ driving. To increase the driving speed to $25 \mathrm{mph}$ (only for the $99^{\text {th }}$ Percentile profile, see Table 3 ), the pulse durations of the "Launch" and "Regen" power pulses were increased by a ratio of $25 / 20 \mathrm{mph}$, with a subsequent decrease in the "Cruise" pulse to maintain a 90-s profile. This resulted in a total energy swing of $30 \mathrm{Wh}$.

Although the cycle-life profiles defined in the FreedomCAR manual are nominally charge neutral (assuming a 90\% round trip efficiency), the actual cycling stability at the target SOC is first established by the operating set point stability (OSPS) test. Generally, the OSPS test consists of 100 consecutive profiles. The requirement is that at its completion, the measured OCV after a $1-\mathrm{h}$ rest is within $2 \%$ of the target OCV. If the OCV shows an unstable effect (i.e., charge positive or charge negative), then a 1-s voltage-controlled discharge step is added at the end of the "Launch" pulse, and/or an adjustment to the "Cruise" pulse power level is made, to achieve stable cycling. The OSPS test is repeated, and the voltage/power levels adjusted, until stable cycling occurs. The cell behavior of the GDR cells was such that the OSPS test required 280 cycles to ensure stability in cycling. 


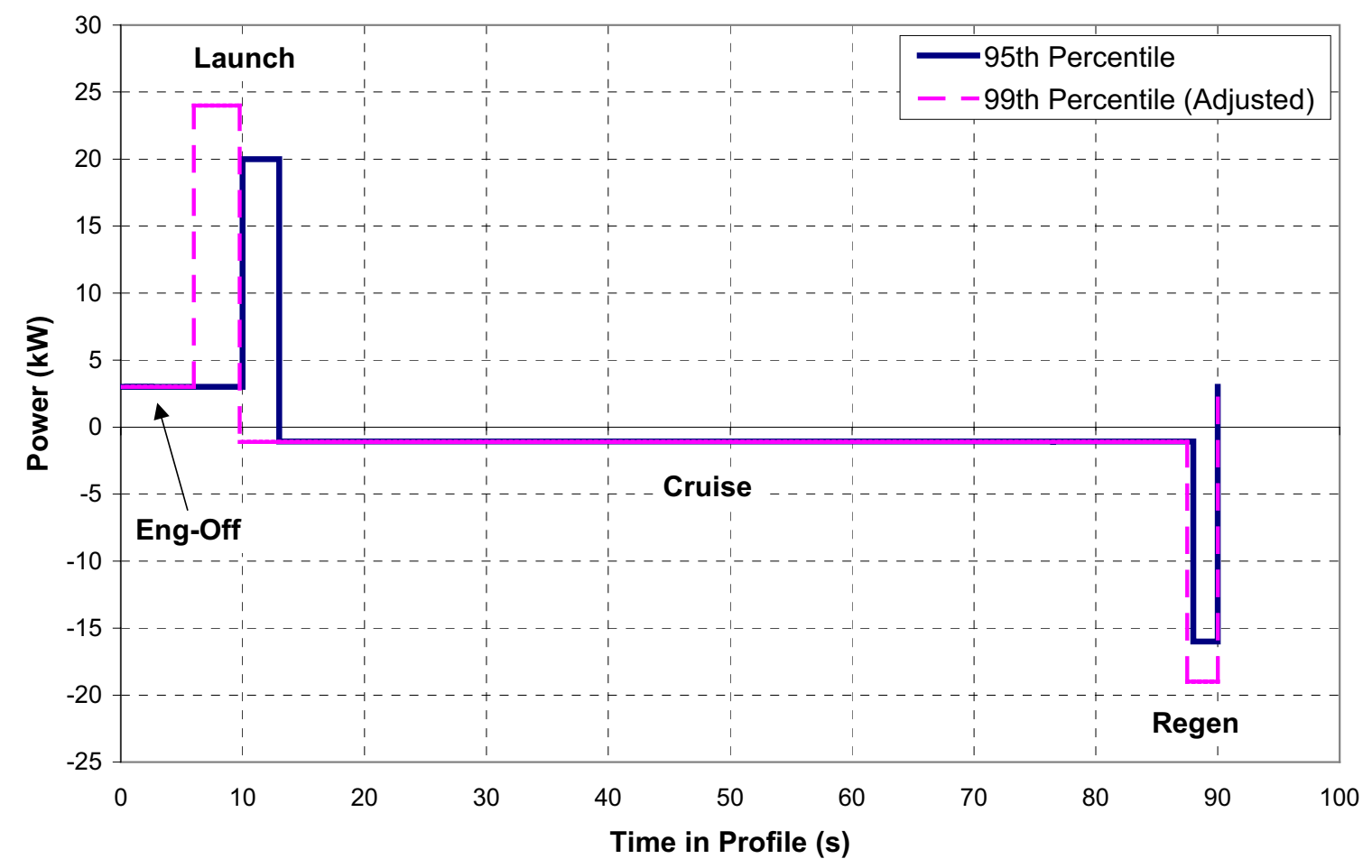

Figure 4. FreedomCAR $95^{\text {th }}$ and $99^{\text {th }}$ Percentile cycle-life profiles.

\subsubsection{Calendar-Life Testing}

Calendar-life testing consisted of resting at OCV and test temperature without any pulse-per-day testing. The voltage was monitored, and if it dropped below a certain threshold, it was taper charged back up to the original OCV at test temperature, and calendar-life aging continued (Reference 4). For the GDR calendar-life cells aging at $\mathrm{SOC}_{\mathrm{MAX}}$ (i.e., $80 \% \mathrm{SOC}$ ), the cells would be recharged if the voltage ever dropped below $\mathrm{SOC}_{\mathrm{MIN}}$ (i.e., $40 \% \mathrm{SOC}$ ). The GDR cells calendar-life aging at $\mathrm{SOC}_{\mathrm{MIN}}$ would have been recharged if the voltage reached $\mathrm{V}_{\text {MIN }}(3.0 \mathrm{~V})$. However, as discussed in Section 4.3.1, none of the cells self-discharged to the voltage limit during a four-week period.

\subsubsection{Path Dependence Testing}

Path dependence testing was meant to verify the assumption that a cell's degradation behavior will be similar regardless of the path taken. A group of cells were cycle-life tested until the discharge resistance growth at $\mathrm{SOC}_{\mathrm{MAX}}$ was $\sim 16 \%$, and then switched to calendar-life testing. Another group did the opposite, starting with calendar-life, then switching to cycle-life.

\subsubsection{RPT Study}

The RPT study was designed to determine the effect of the MPPC test compared to the standard FreedomCAR RPT, which consists of a $\mathrm{C}_{1} / 1$ discharge and L-HPPC test. Consequently, groups of cells were tested using the most benign and most harsh conditions of the TLVT cycle-life test matrix (i.e., Cycle-Life 1 and Cycle-Life 8 in Table 3, respectively), but with a standard FreedomCAR RPT instead of the newly devised TLVT MPPC. 


\subsection{Reference Performance Testing}

Life testing for the Gen 2 GDR cells was interrupted every four weeks (i.e., 26880 cycle-life profiles) for reference performance testing. Most cells (other than the RPT study group) were subjected to the newly developed MPPC test, which was designed to measure changes in resistance as a function of test time (Figure 3 ). As mentioned above, the RPT study group was subjected to a $\mathrm{C}_{1} / 1$ discharge and LHPPC test instead. These tests were designed to quantify changes in capacity, resistance, power, and energy as a function of test time. ASI growth is the percentage increase in cell ASI during the MPPC or L-HPPC test. Capacity fade is the percentage loss in the discharge capacity during the $\mathrm{C}_{1} / 1$ test. Power fade is the percentage loss in the power at $300 \mathrm{Wh}$ from the L-HPPC test (Reference 6). The fades are normalized to the characterization RPT (i.e., at characterization, the ASI growth and capacity and power fades are all $0 \%$ ). 


\section{RESULTS}

Prior to assembly, the GDR cells were left in a glove box, unsealed, for approximately nine months, and previous calendar-life testing at the ANL showed very poor performance compared to the Baseline and Variant C cells (Reference 2). Consequently, the cells designated for TLVT testing were primarily used to help refine the manual, and were not used for validation purposes. The test results for these cells, as discussed below, also showed very poor performance.

Due to the large number of test conditions (see Table 3), only cell averages or results from representative cells are presented in this section. Individual cell data (e.g., capacity fade, ASI growth, etc.) are shown in Appendix B. Also, a group identifier has been established for this report of the form "AABbCC." The first two characters identify the SOC (i.e., 40 or $80 \%$ ). The middle character(s) represent the life test condition (i.e., " 5 " for the $95^{\text {th }}$ Percentile, "9" for the $99^{\text {th }}$ Percentile, "C" for calendar-life testing). An additional character is required for the path dependence group (e.g., " $5 \mathrm{C}$ " represents a path dependence group that began with cycle-life testing and switched to calendar-life). The last two characters represent the test temperature (i.e., 40,50 , or $60^{\circ} \mathrm{C}$ ). For example, a test condition of " 40950 " would represent the group of cells that were cycle-life tested at $40 \%$ SOC and $50^{\circ} \mathrm{C}$ using the $99^{\text {th }}$ Percentile profile.

\subsection{Capacity}

\subsubsection{OCV vs. SOC}

As discussed in Section 3.2, the GDR cell OCV vs. SOC was based on $\mathrm{C}_{1} / 1$ discharges in $5 \%$ SOC increments with one-hour rests between each increment (unlike the Gen 2 Baseline and Variant $\mathrm{C}$ cells, whose SOCs were based on a continuous full $\mathrm{C}_{1} / 25$ discharge, Reference 2). Figure 5 shows the voltage as a function of calculated SOC for a representative GDR cell. The SOCs were determined from the measured capacity of the cell (not rated capacity). Although the GDR cells were never subjected to a $\mathrm{C}_{1} / 25$ test, other cell chemistries have indicated that the TLVT method and the full $\mathrm{C}_{1} / 25$ discharge yield similar results. The resulting average OCVs corresponding to $\mathrm{SOC}_{\mathrm{MAX}}$ and $\mathrm{SOC}_{\mathrm{MIN}}$ for each life-test group were determined from piecewise linear interpolation (Reference 4) and are shown in Table 5. These values were used for subsequent life and reference performance testing.

Table 5. OCV versus SOC for the GDR cell groups.

\begin{tabular}{ccc}
\hline \hline Cell Group & OCV at SOC $_{\mathrm{MAX}}$ & OCV at SOC $_{\mathrm{MIN}}$ \\
\hline \hline Cycle-Life & $3.918 \mathrm{~V}$ & $3.625 \mathrm{~V}$ \\
Calendar-Life & $3.913 \mathrm{~V}$ & $3.621 \mathrm{~V}$ \\
Path Dependence & $3.917 \mathrm{~V}$ & $3.624 \mathrm{~V}$ \\
RPT Study & $3.918 \mathrm{~V}$ & $3.625 \mathrm{~V}$ \\
\hline \hline
\end{tabular}




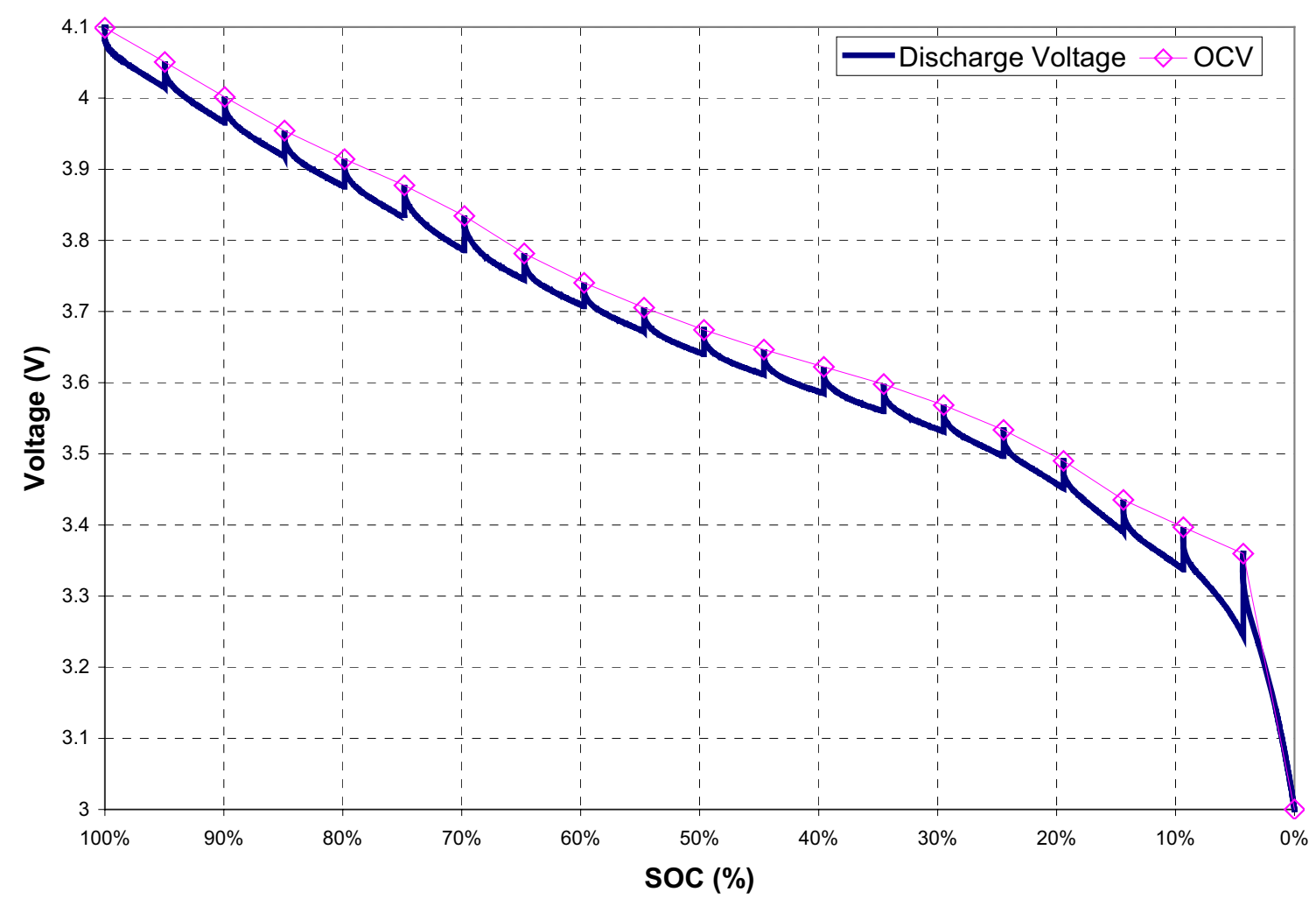

Figure 5. OCV as a function of SOC for a representative GDR cell.

\subsubsection{Discharge Capacity}

Figure 6 shows the average capacities for each test group for the TLVT cycle- and calendar-life cells through 36 weeks of aging. These capacities were measured from the $\mathrm{C}_{1} / 1$ discharge between $\mathrm{SOC}_{\mathrm{MAX}}$ and $\mathrm{SOC}_{\mathrm{MIN}}$ at $30^{\circ} \mathrm{C}$ (data do not include the taper discharge at $\mathrm{SOC}_{\mathrm{MIN}}$ ). The biggest change occurs between characterization and four weeks, which is consistent with the Gen 2 Baseline and Variant $\mathrm{C}$ cell results. This behavior may be related to incomplete formation of the solid electrolyte interphase layer (Reference 2). For the cycle-life cells, there does not appear to be any profile dependency (i.e., power ratio does not appear to be a stress factor for these cells), since the capacity fade rates between the $95^{\text {th }}$ and $99^{\text {th }}$ Percentile profiles are similar within each temperature and SOC condition. There is a small temperature effect for the cycle-life cells aged at $\mathrm{SOC}_{\mathrm{MIN}}$ since the $50^{\circ} \mathrm{C}$ cell groups show a slightly higher capacity fade than at $40^{\circ} \mathrm{C}$. The temperature effect is more pronounced for the cells aged at SOC $_{\text {MAX }}$. The calendar-life cells also show a small temperature effect, and slightly greater fade than the corresponding cycle-life cells after 28 weeks of aging. This is the opposite trend seen with the Baseline and Variant $\mathrm{C}$ cells, where the cycle-life cells faded more quickly (Reference 2 ). The performance trends may be attributable to the difference in calendar-life testing (the Gen 2 Baseline and Variant $\mathrm{C}$ calendarlife cells were clamped at a designated voltage with a pulse per day whereas the GDR cells were left at $\mathrm{OCV}$, see Section 3.3.2). Another source for the different performance trends may by the various cell lot numbers used for each group (see Table 4).

Figure 7 shows the average capacities for each test group in the supplemental matrices (path dependence and RPT study). These data also show a larger drop in available capacity between characterization and four weeks. As mentioned in Section 3.3.3, the switch from calendar- to cycle-life (or vice versa) for the path dependence cells occurred when they showed approximately $16 \%$ ASI growth. 
One group switched after only eight weeks of aging, another two groups were switched after 16 weeks, and the last group (405C40) never showed that much impedance growth. The data show roughly similar capacity fades to the corresponding cycle-life cells. However, the question concerning path dependence is inconclusive (especially when ASI is also considered, see Section 4.2), and may be attributable to the mixture of cells from different lot numbers. The capacities from the RPT study groups are significantly larger than the other groups because they are based on a full discharge (not between $\mathrm{SOC}_{\mathrm{MAX}}$ and $\mathrm{SOC}_{\mathrm{MIN}}$ ). The fade rate for the 40540 group is similar to the corresponding MPPC group (see Figure 6). However, the 80950 group showed greater fade than its counterpart in Figure 6, having reached EOT after only 20 weeks of aging.

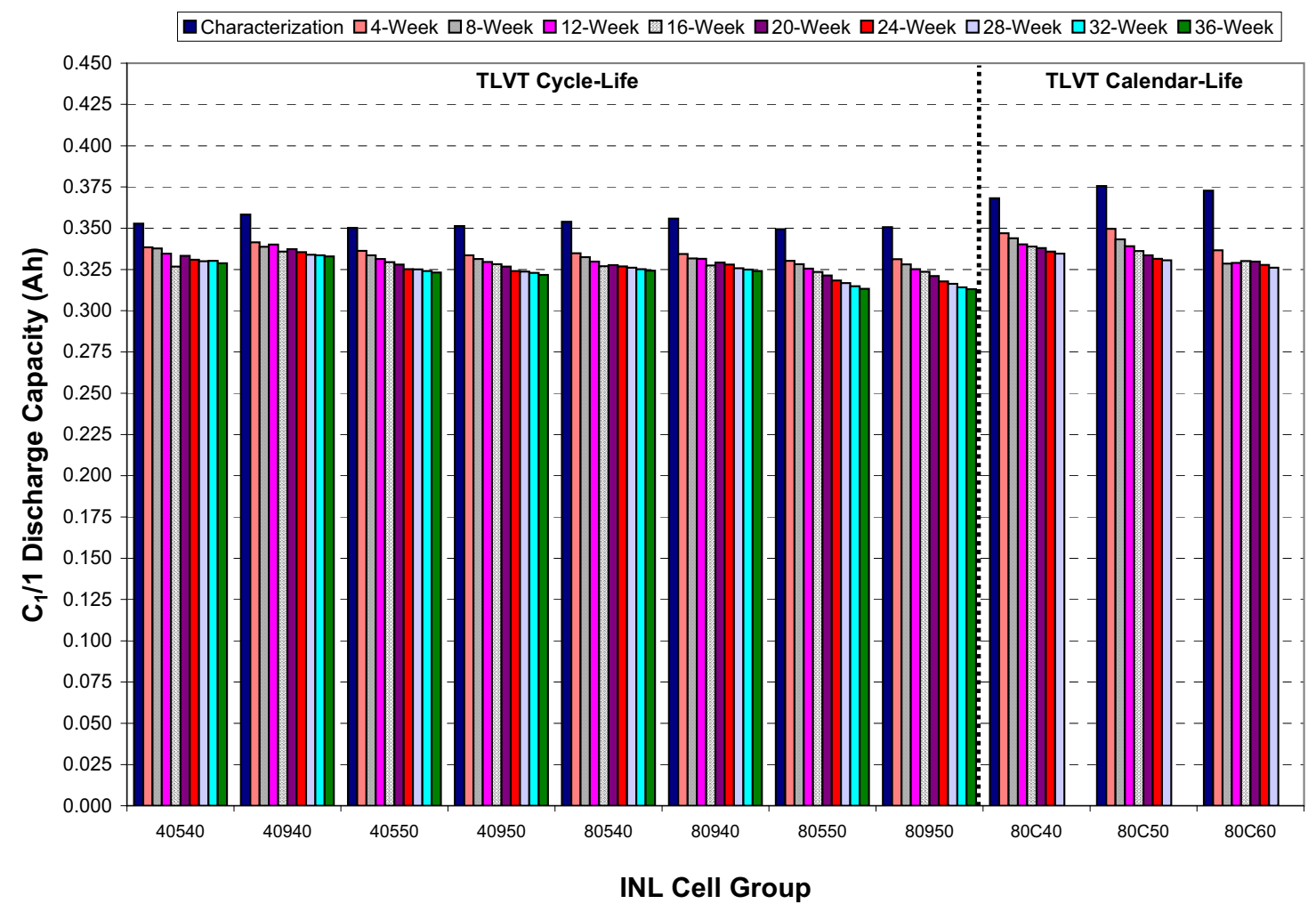

Figure 6 . Average $\mathrm{C}_{1} / 1$ static capacity for each TLVT core-life matrix group. 


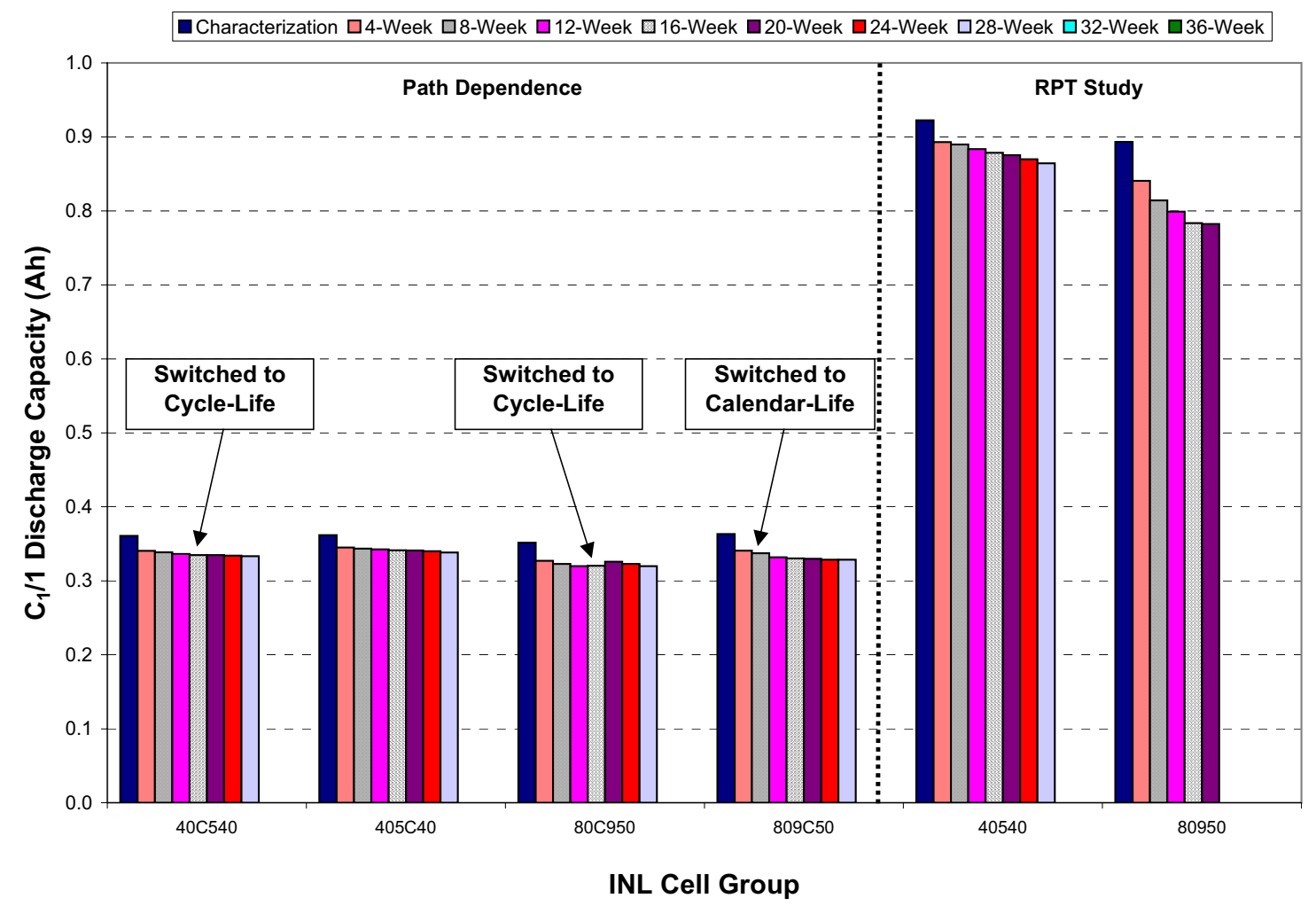

Figure 7. Average $C_{1} / 1$ static capacity for each TLVT supplemental matrix group.

\subsection{Area Specific Impedance}

\subsection{1 $\mathrm{SOC}_{\mathrm{MIN}}$}

Figure 8 shows the average $30^{\circ} \mathrm{C}$ discharge ASIs at $\mathrm{SOC}_{\mathrm{MIN}}$ as a function of test time for the TLVT cycle- and calendar-life core matrix groups. As seen with the capacity data, there is a significant increase in ASI between characterization and four weeks. The cycle-life cells do not appear to show any profile or throughput dependency, but generally show a slight temperature and SOC dependence. The calendar-life cells faded approximately twice as fast as the cycle-life cells, and showed an obvious temperature dependency.

Figure 9 shows the average $30^{\circ} \mathrm{C}$ discharge $\mathrm{ASI}$ at $\mathrm{SOC}_{\mathrm{MIN}}$ as a function of test time for the supplemental matrices. Based on the data from Figure 8, the cell groups that started with calendar-life (i.e., 40C540 and 80C950) should show a higher initial fade rate. This appears to be the case for the cells aged at $\mathrm{SOC}_{\mathrm{MIN}}$ (i.e., 40C540), but the opposite is true for the cells aged at $\mathrm{SOC}_{\mathrm{MAX}}$ (i.e., 80C950 and 809C50). This, combined with the various lot numbers used in these groups, lead to inconclusive results about path dependence. Similarly, the RPT study cell groups came from a mixture of lot numbers, and the cells degraded too quickly to determine any effects between the L-HPPC and MPPC tests. 


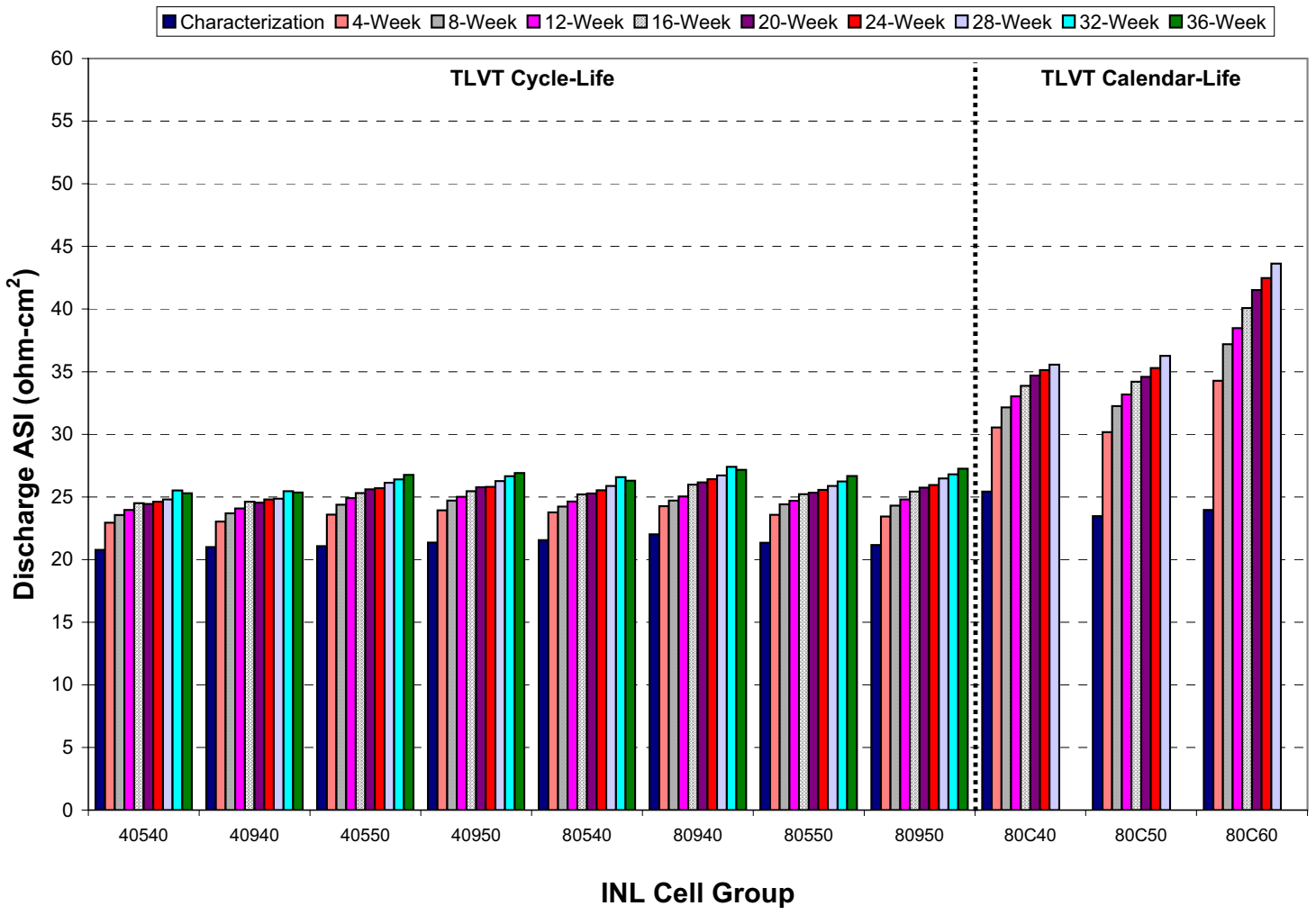

Figure 8. Average discharge ASI at $\mathrm{SOC}_{\mathrm{MIN}}$ for each TLVT core-life matrix group.

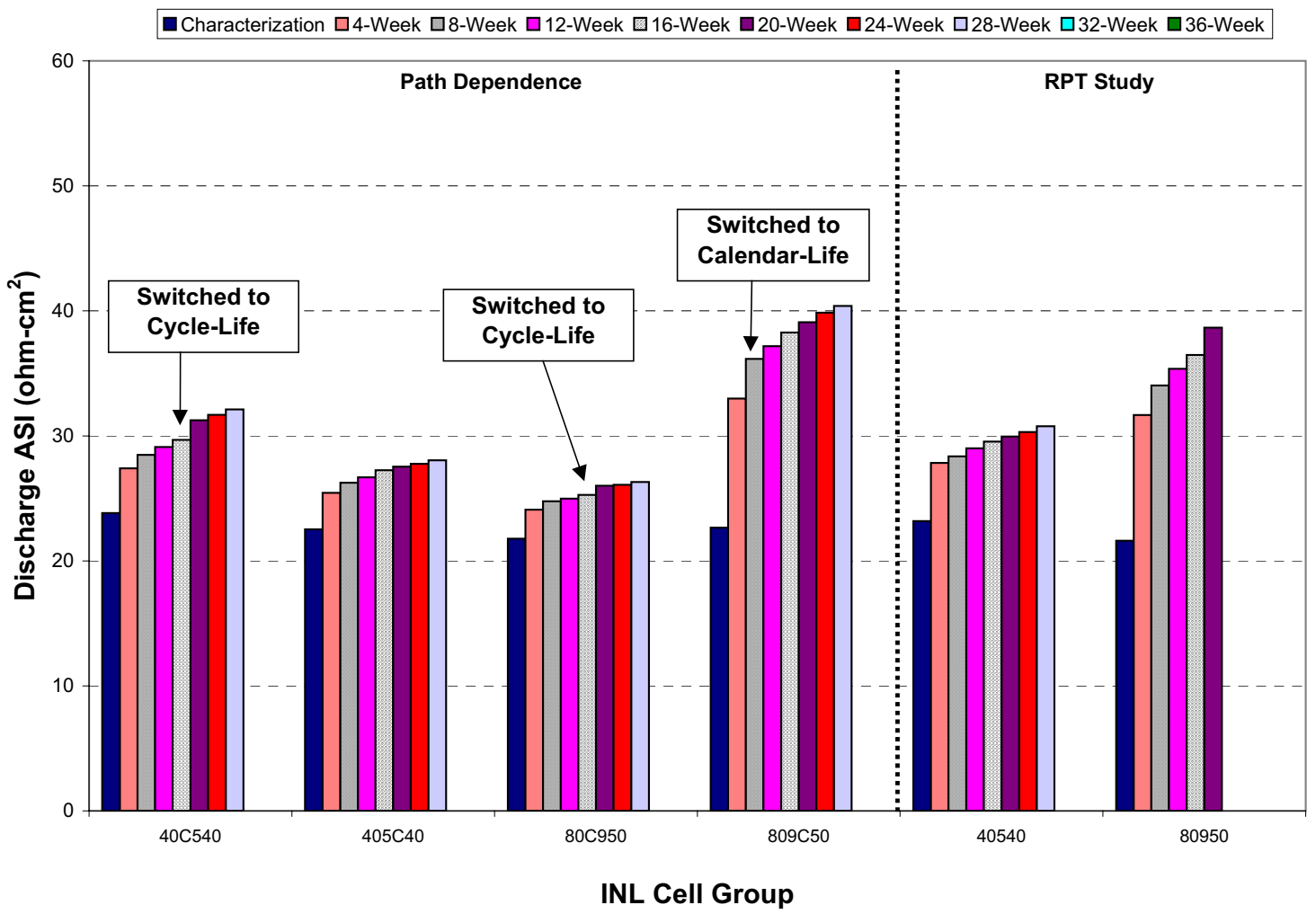

Figure 9. Average discharge ASI at $\mathrm{SOC}_{\mathrm{MIN}}$ for each TLVT supplemental matrix group. 


\subsection{2 $\mathrm{SOC}_{\operatorname{MAX}}$}

Figure 10 shows the average $30^{\circ} \mathrm{C}$ discharge ASI at $\mathrm{SOC}_{\mathrm{MAX}}$ as a function of test time for the TLVT cycle- and calendar-life core matrix groups. These data show similar trends to those observed at $\mathrm{SOC}_{\mathrm{MIN}}$ (Figure 8), with a slight temperature and SOC dependence and no apparent effect due to throughput or power ratio. Interestingly, the cycle-life cells show more overall ASI growth at $\mathrm{SOC}_{\mathrm{MIN}}$ whereas the calendar-life cells show slightly more overall ASI growth at $\mathrm{SOC}_{\mathrm{MAX}}$. A significant reason for this effect is that the cycle-life ASI at SOC $_{\mathrm{MAX}}$ does not show a large increase between characterization and the first four weeks of aging, but the calendar-life cells do show that increase. These data indicate that the most stressful acceleration factor for the GDR cells is SOC.

Figure 11 shows the average $30^{\circ} \mathrm{C}$ discharge $\mathrm{ASI}$ at $\mathrm{SOC}_{\mathrm{MAX}}$ as a function of test time for the cells in the supplemental test matrix. Although the data are inconclusive, the path dependence results at $\mathrm{SOC}_{\mathrm{MAX}}$ show a little more consistency with the core-life test matrix results. Cells that started with calendar-life showed a higher growth rate than when the cells are switched to cycle-life testing, as was the case for Groups 40C540 and 80C950 (as expected, based on Figure 10). Conversely, Group 809C50 showed a slight increase in growth rate between 8- and 12-weeks of aging once the cells were switched from cycleto calendar-life. The behavior of the cells, however, is erratic, and show an improvement in ASI after the switch from calendar- to cycle-life (unlike the behavior at $\mathrm{SOC}_{\mathrm{MIN}}$, see Figure 9). Similarly, the RPT study groups faded too quickly to draw any conclusions about performance.

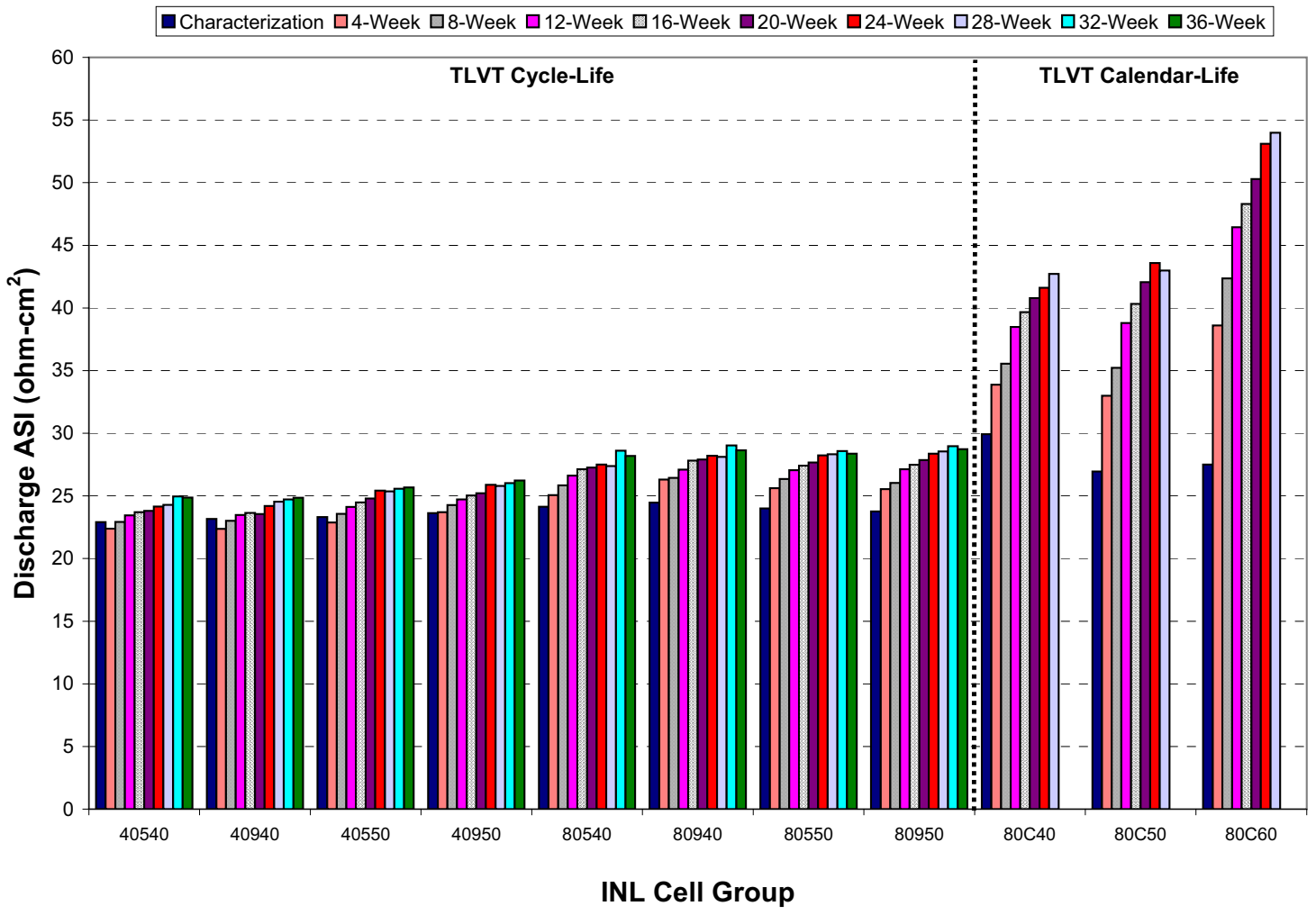

Figure 10. Average discharge ASI at $\mathrm{SOC}_{\mathrm{MAX}}$ for each TLVT core-life matrix group. 


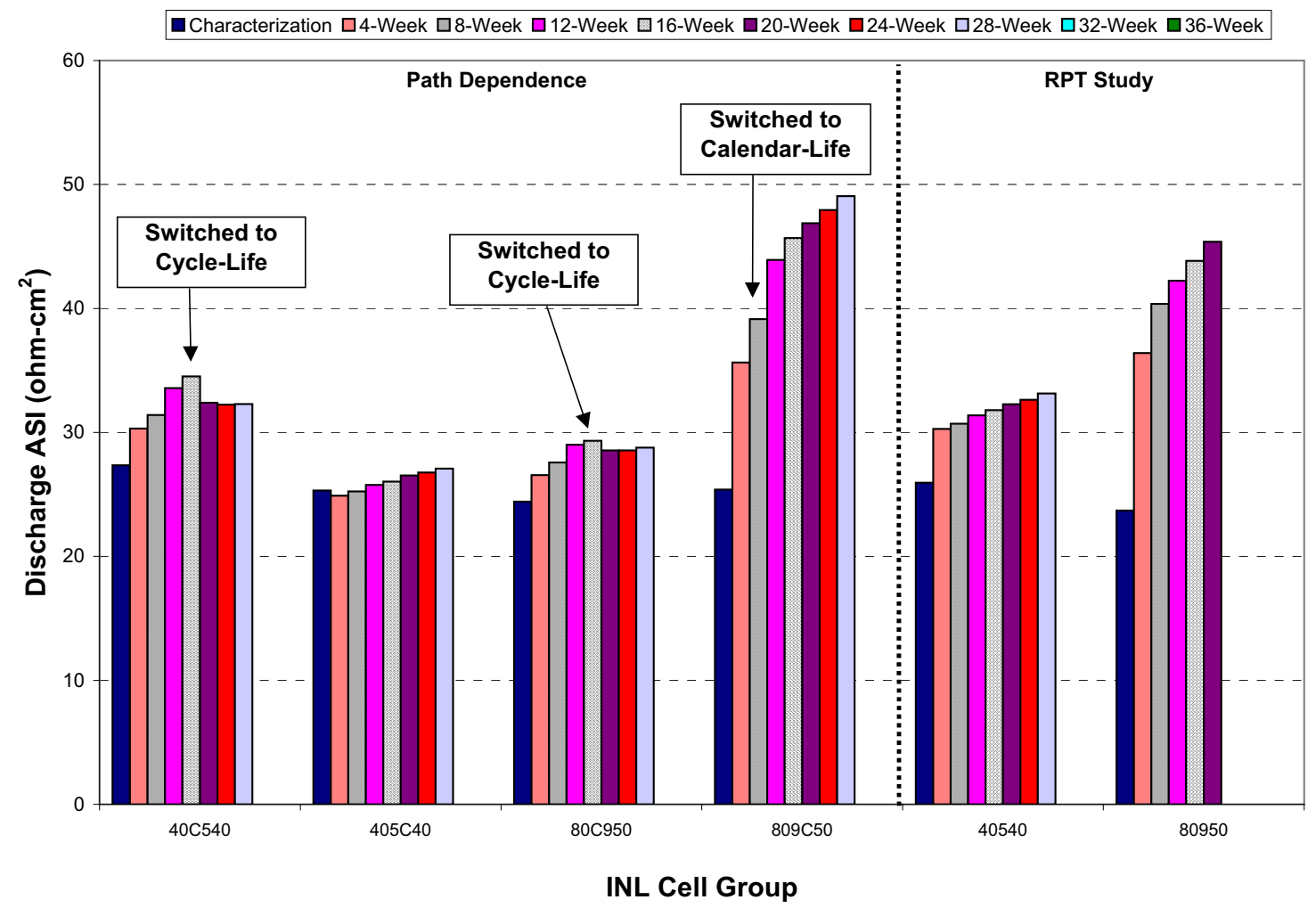

Figure 11. Average discharge ASI at $\mathrm{SOC}_{\mathrm{MAX}}$ for each TLVT supplemental matrix group.

\subsection{Life Testing}

\subsubsection{Calendar-Life}

Figure 12 shows the voltage self-discharge during calendar-life testing at $\mathrm{SOC}_{\mathrm{MAX}}$ for representative Gen 2 GDR core-life cells tested at 40,50 , and $60^{\circ} \mathrm{C}$. The self-discharge for all cells was slow enough not to require any recharging during a four-week period. The BOL initial voltages are slightly lower primarily because of a programming glitch that resulted in an extra eight-hour rest at OCV prior to the start of the calendar-life test. The voltage self-discharge generally increases as a function of test temperature. Interestingly, after 16 weeks of aging, both the 40 and $50^{\circ} \mathrm{C}$ groups tend to stabilize in selfdischarge whereas the $60^{\circ} \mathrm{C}$ group continues to improve. Consequently, the $50^{\circ} \mathrm{C}$ group ends up showing the most drift after 28 weeks of aging instead of the $60^{\circ} \mathrm{C}$ group. This may be attributable to a much higher ASI growth rate at $60^{\circ} \mathrm{C}$ (see Figure 10), thus increasing the competing reactions to self-discharge. 


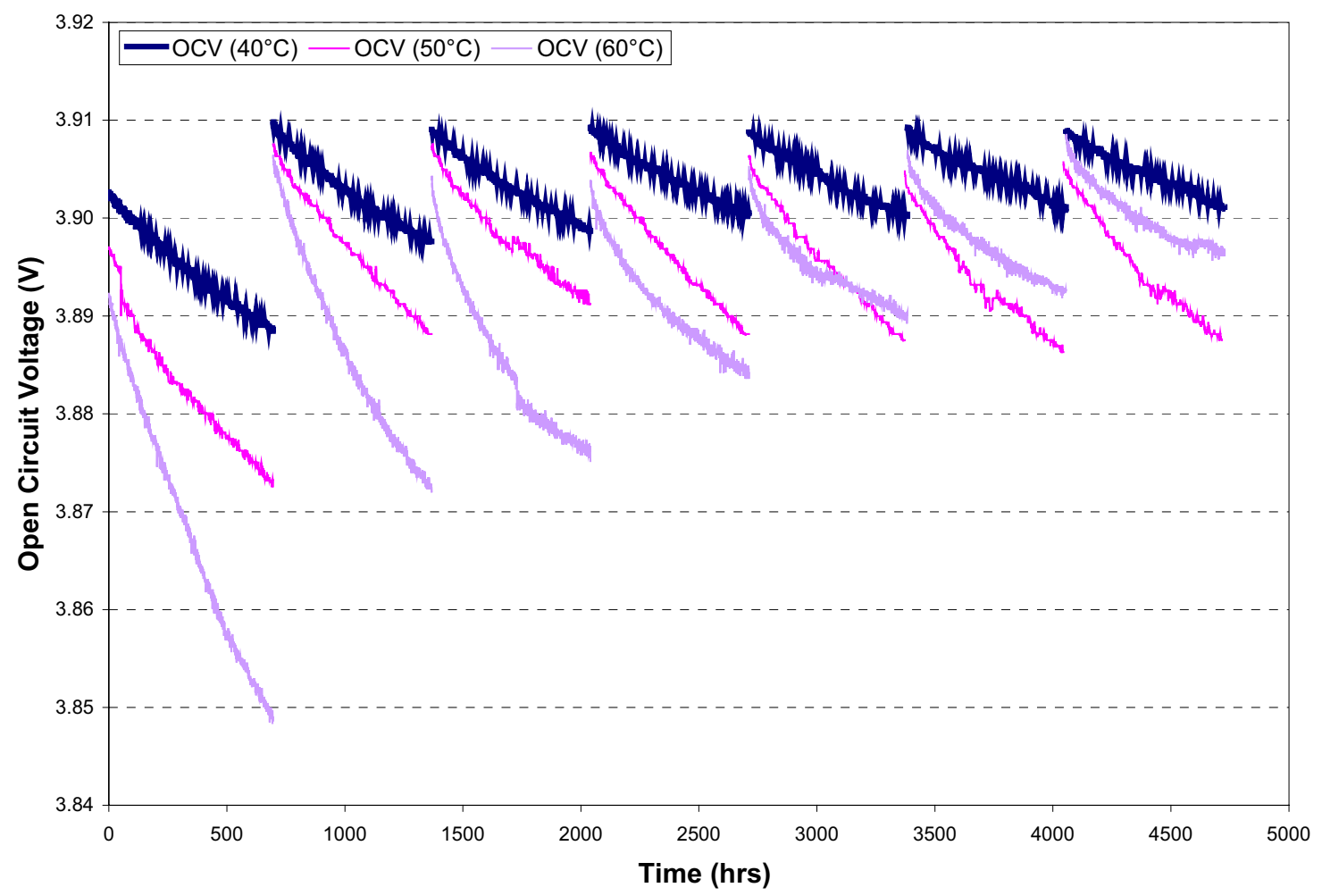

Figure 12. Calendar-life self discharge for representative cells at 40,50 , and $60^{\circ} \mathrm{C}$.

\subsubsection{Cycle-Life Pulse Resistance}

Figures 13 and 14 show the discharge and regen pulse resistances (as calculated from the "Launch" and "Regen" pulses for representative cells in the 40540 and 40950 groups, respectively). Pulse resistances are calculated using the first 280 and last 100 pulses, and every one hundredth pulse in between. The data show slight discontinuities every 672 hours, coincident with the MPPC test. The growth in pulse resistance as a function of test time is similar regardless of test profile or temperature. Figures 15 and 16 show the pulse resistances for representative cells in the 80540 and 80950 groups, respectively. These data show a significantly greater drop in pulse resistance every four weeks as a result of the MPPC test. Furthermore, the growth in pulse resistance is greater than the corresponding groups aged at $\mathrm{SOC}_{\mathrm{MIN}}$ (compare Figures 13 and 15, and Figures 14 and 16). These observations also indicate that SOC is the highest stress factor for the GDR cells. Figure 15 also shows one of the reasons why the GDR cell behavior was so erratic, and observed trends inconclusive. Several cells were having difficulty maintaining their control voltages during cycling since the resistance was changing so fast, particularly at beginning of life. Consequently, the pulse profile would quickly ramp up to the maximum voltage and show a sudden jump in pulse resistance (e.g., at approximately 1400 hours in Figure 15). The 20-week pulse resistance data for Figure 16 shows a dip due to a rise of the chamber temperature, increasing to as high as $53^{\circ} \mathrm{C}$.

One of the objectives of MPPC was to minimize the post-RPT discontinuities. However, as seen in Figures 13 through 16, it does not accomplish this goal. Figure 17 shows the discharge pulse resistance data from Figures 13 and 16 normalized to a representative Gen 2 Baseline cell cycle-life tested at $45^{\circ} \mathrm{C}$ and $60 \%$ SOC (Reference 2 ). The Gen 2 cell RPT consisted of numerous tests, including a full $\mathrm{C}_{1} / 1$ and L-HPPC. It was determined that a full discharge and charge is the primary source of the discontinuity (Reference 8). The MPPC was designed to avoid full charges and discharges, and only operate between 
two SOC conditions. However, as shown in Figure 17, the MPPC discontinuity at $80 \%$ SOC is just as much as was seen for the $45^{\circ} \mathrm{C}$ Baseline cells. Note that the noisy Gen 2 Baseline cell data is primarily due to the old INL calibration process. The calibration routine was updated prior to the GDR cell testing (References 9 and 10), and the data collected are noticeably improved.

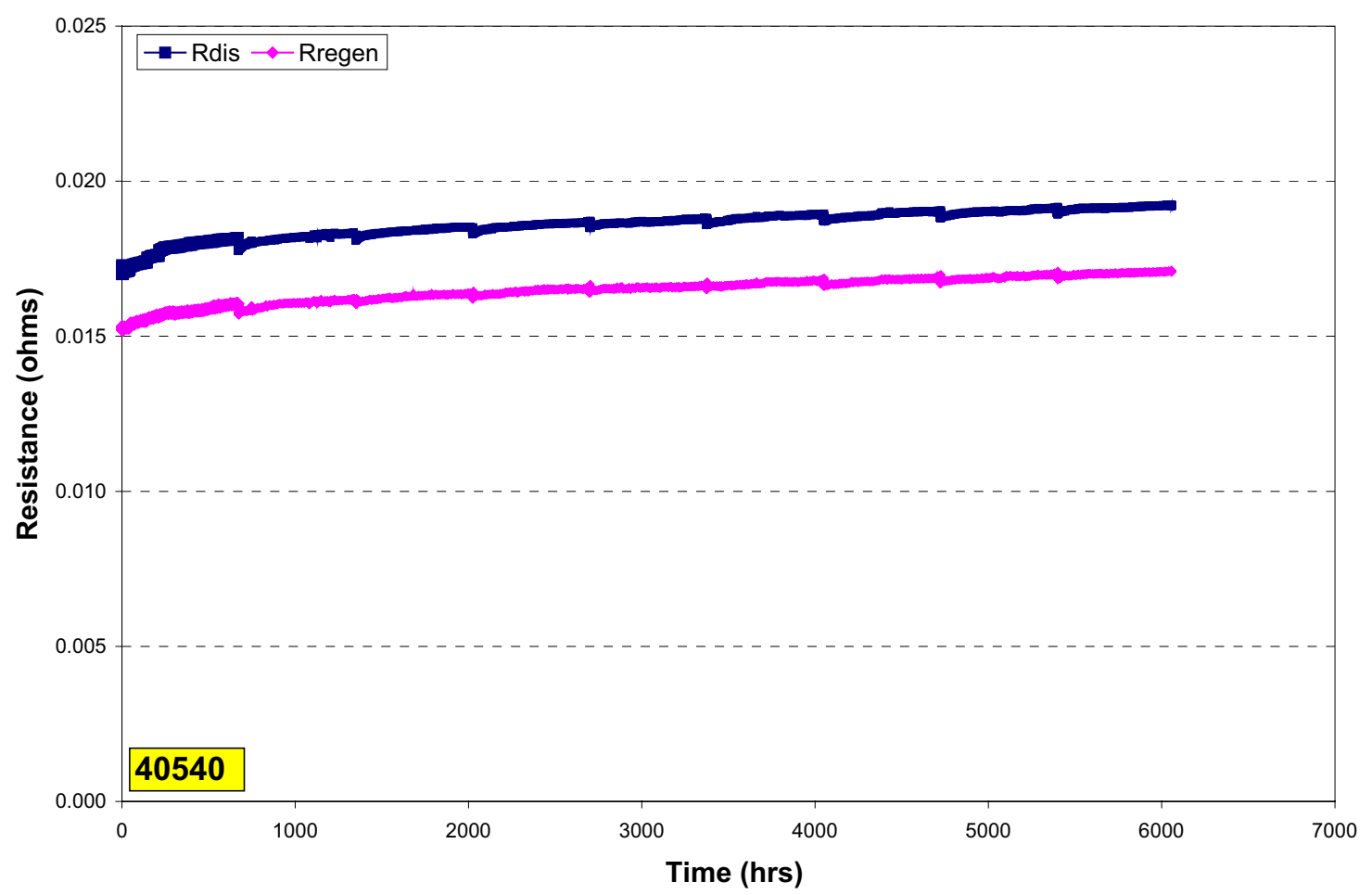

Figure 13. Cycle-life pulse resistance for a representative cell at the 40540 condition. 


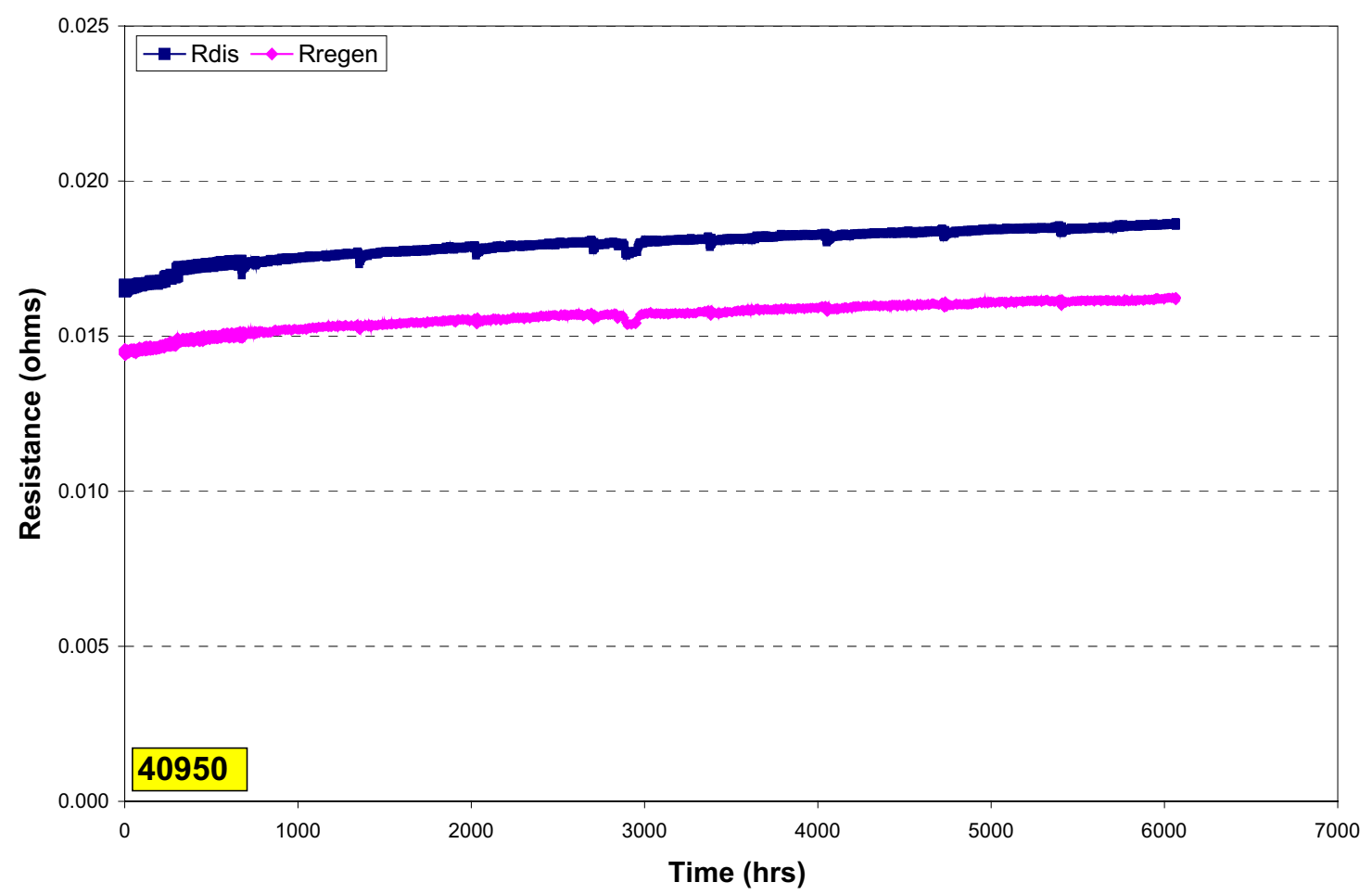

Figure 14. Cycle-life pulse resistance for a representative cell at the 40950 condition.

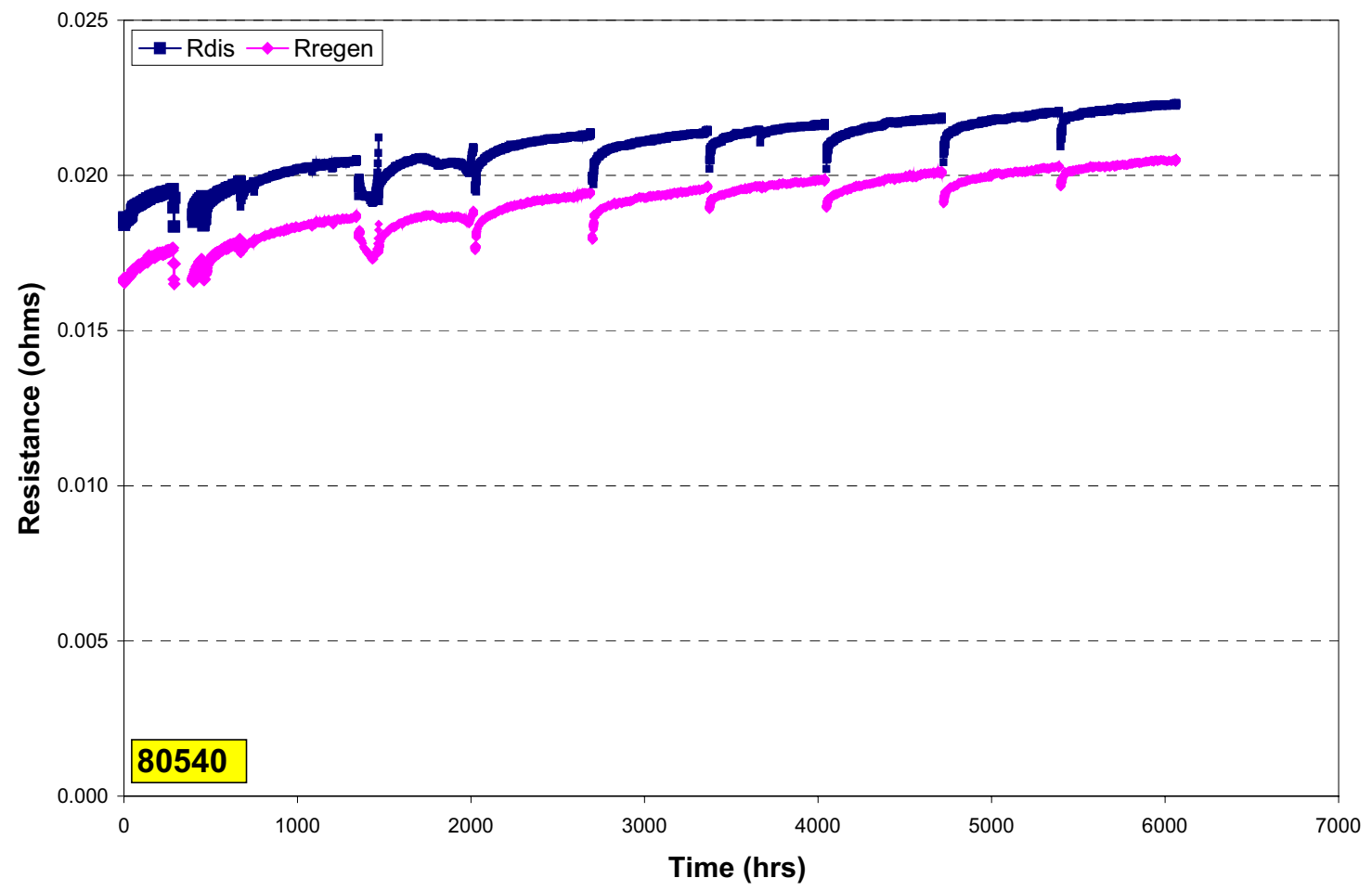

Figure 15. Cycle-life pulse resistance for a representative cell at the 80540 condition. 


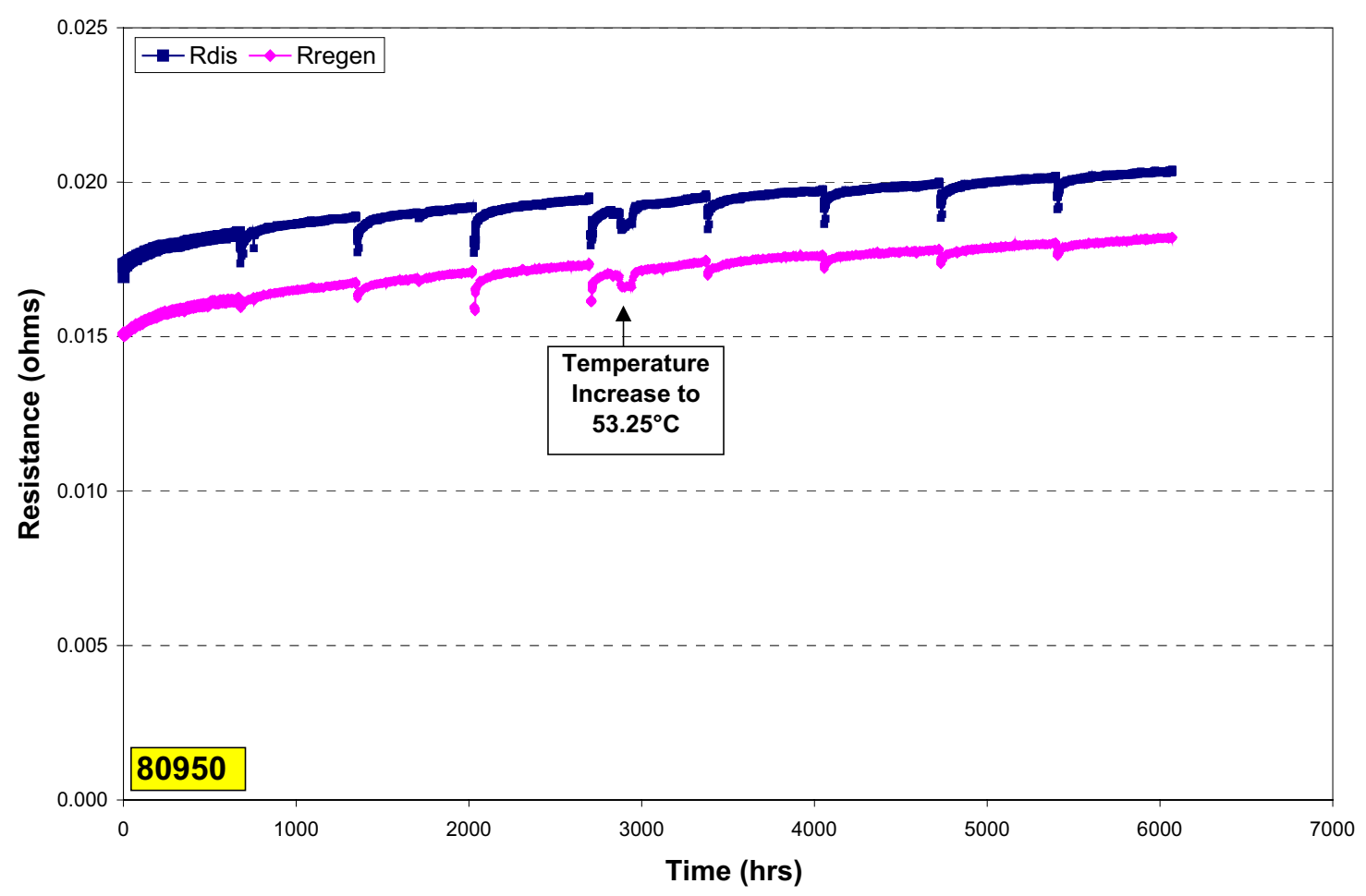

Figure 16. Cycle-life pulse resistance for a representative cell at the 80950 condition.

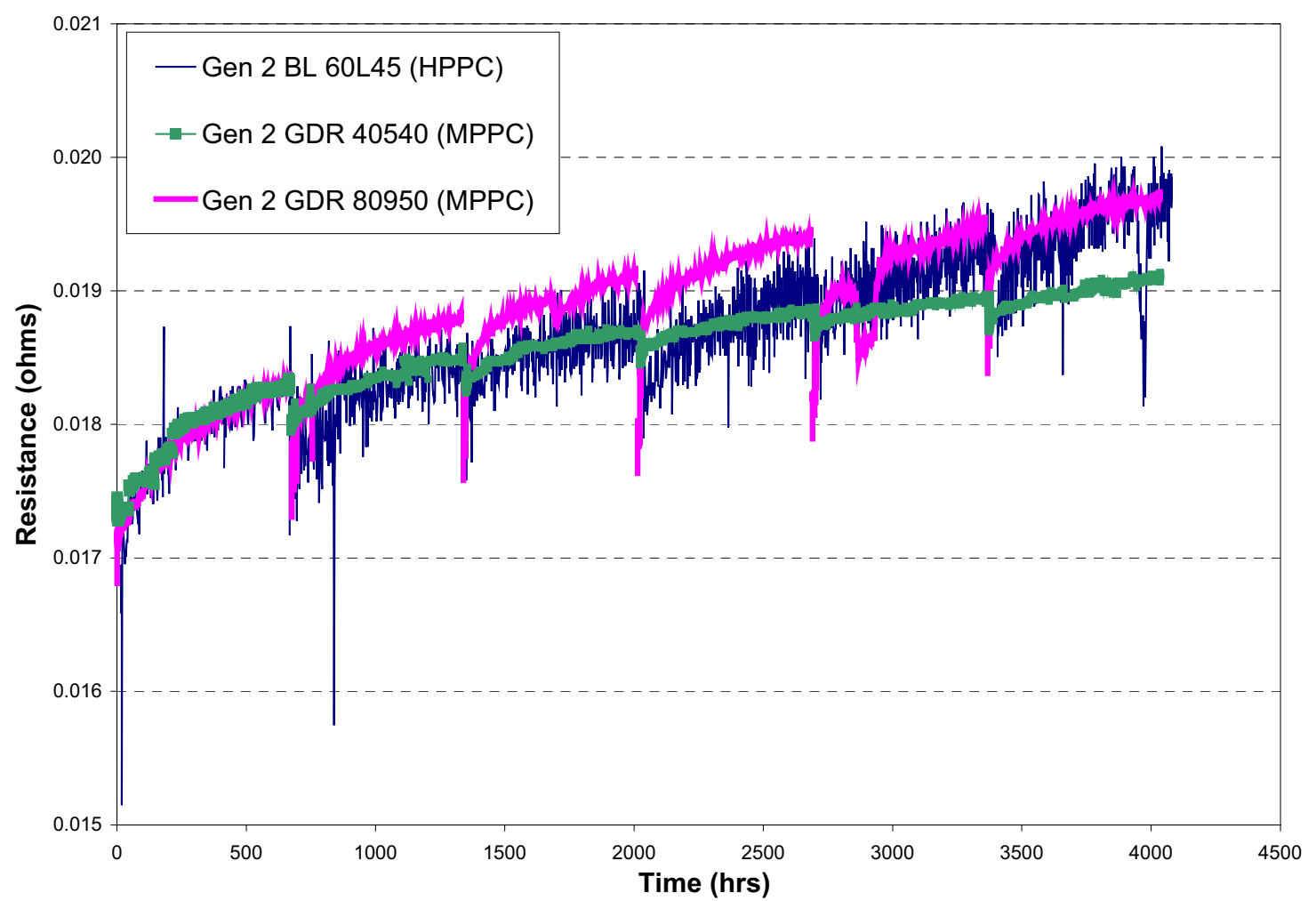

Figure 17. Comparison of pulse discontinuity between Gen 2 Baseline and GDR cells. 


\subsection{TLVT Applications}

\subsubsection{Temperature Compensation}

One of the advantages of the MPPC test is that the profile shown in Figure 3 is repeated once at the life test temperature, and once at the reference temperature. From these data, a temperature compensated ASI at the exact reference temperature (e.g., $30^{\circ} \mathrm{C}$ ) can be calculated using the methodology defined in the TLVT Manual (Reference 4). Figure 18 shows the average discharge ASI at $\mathrm{SOC}_{\mathrm{MIN}}$ as a function of test time for both the calculated and temperature-adjusted values for cell group 80950. The INL temperature control is very stable and the compensation does not yield significant differences in performance results. These data are generally representative of all cell groups and SOC conditions with respect to the effect of temperature compensation.

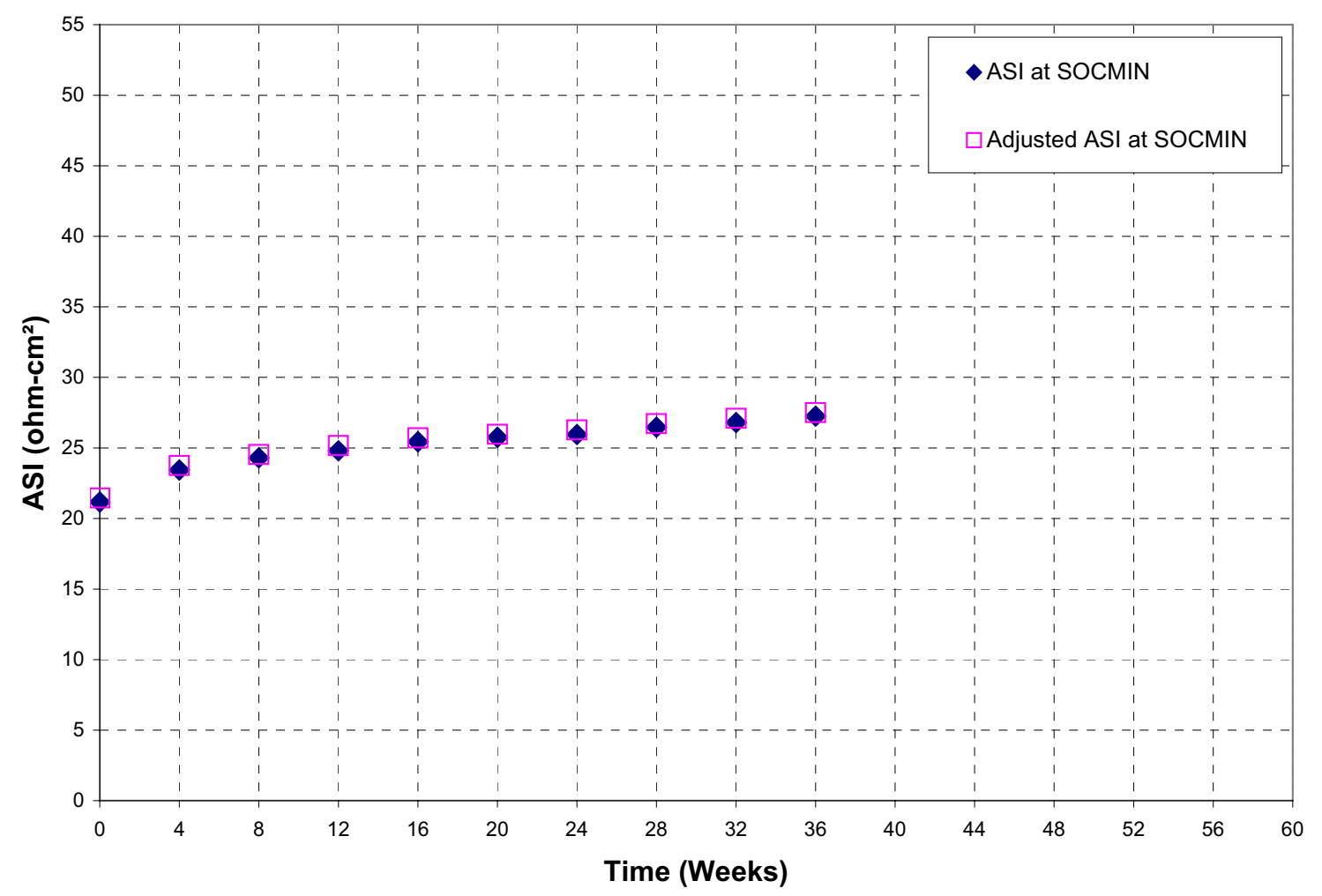

Figure 18. Effect of temperature compensation on the GDR cells (e.g., 80950 at $\mathrm{SOC}_{\mathrm{MIN}}$ )

\subsubsection{Effects of MPPC vs. L-HPPC}

The TLVT Manual also requires a statistical comparison between the L-HPPC and MPPC ASI data at characterization (Reference 4). The ASI means and standard deviations for $\mathrm{SOC}_{\mathrm{MAX}}$ and $\mathrm{SOC}_{\mathrm{MIN}}$ are determined from both the L-HPPC and MPPC tests, and a t-statistic is used to verify the null hypothesis that the two means are not statistically different. For the 16 GDR cycle-life cells, the null hypothesis must be rejected if $|t|>t_{0.025}$ for $\left(\mathrm{N}_{\mathrm{HPPC}}-1\right)$ degrees of freedom (i.e., $\left.|\mathrm{t}|=2.13\right)$. At $\mathrm{SOC}_{\mathrm{MAX}},|\mathrm{t}|=3.25$, and at $\mathrm{SOC}_{\mathrm{MIN}},|\mathrm{t}|=1.81$. Therefore, the null hypothesis must be rejected at $\mathrm{SOC}_{\mathrm{MAX}}$, indicating that the MPPC and L-HPPC do not yield similar results. Figure 19 shows the differences in ASIs between the two tests for all of the INL cycle-life cells. The MPPC consistently over-predicts the L-HPPC data. Similar observations were seen with other, commercially available cells as well (Reference 8). 


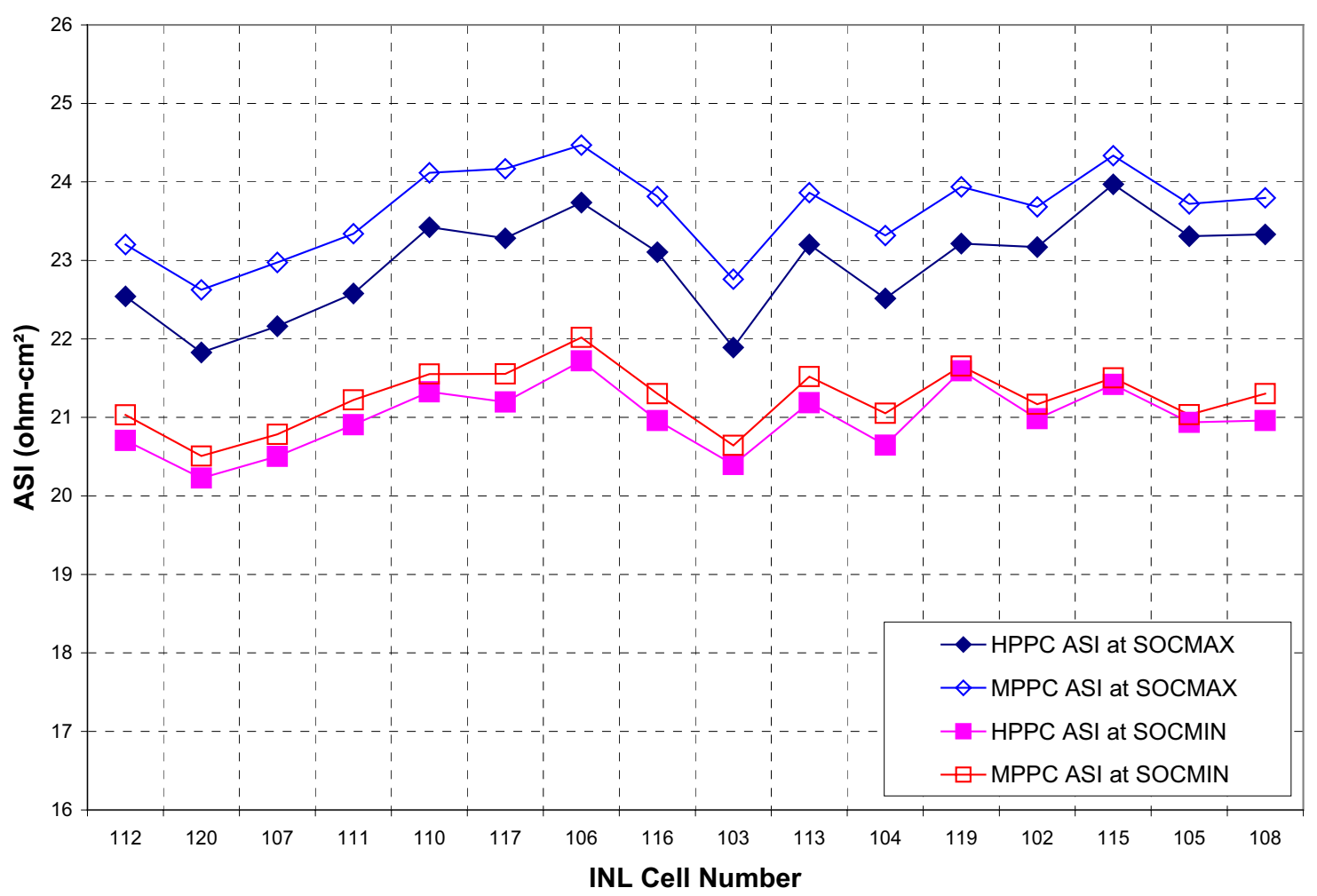

Figure 19. Difference between HPPC and MPPC ASIs at $\mathrm{SOC}_{\mathrm{MAX}}$ and $\mathrm{SOC}_{\mathrm{MIN}}$ for the cycle-life cells

\subsubsection{ASI Noise Characterization}

For accurate life predictions, the TLVT methodology requires cells with a high degree of reproducibility with minimal cell-to-cell variations. Unfortunately, using the noise characterization technique defined in the manual (Reference 4), the GDR cells showed a very high manufacturing variability. The manufacturing variability is split between differences in cell-to-cell electrode areas $\left(\mathrm{S}_{\text {AREA }}\right)$, and differences in cell-to-cell fixed ohmic resistance $\left(\mathrm{S}_{\text {OHMIC }}\right)$. The default values for these variations in the manual are 0.5 and $1.0 \%$, respectively. The measurement error $\left(\mathrm{S}_{\mathrm{MEAS}}\right)$ also needs to be minimal so that cell testing does not negatively impact life projections. The GDR variability is shown in Table 6. Although the GDR manufacturing variabilities are high, the measurement error is very low due to the INL calibration processes (References 9 and 10).

Table 6. ASI noise characterization.

\begin{tabular}{ccc}
\hline \hline Standard Deviation & TLVT Default Values & Temperature-Compensated ASI \\
\hline \hline $\mathrm{S}_{\text {MEAS }}$ & $1.0 \%$ & $0.51 \%$ \\
$\mathrm{~S}_{\text {AREA }}$ & $0.5 \%$ & $2.27 \%$ \\
$\mathrm{~S}_{\text {OHMIC }}$ & $1.0 \%$ & $7.58 \%$ \\
\hline \hline
\end{tabular}




\section{CONCLUSIONS}

Testing and analysis of the ATD Gen 2 GDR cells has been completed. The purpose of these cells was primarily to assess the newly developed TLVT procedures and profiles. Cells were subjected to various calendar- and cycle-life testing in both core and supplemental matrices. Reference performance testing primarily consisted of the minimum pulse power characterization test instead of the standard FreedomCAR $\mathrm{C}_{1} / 1$ and L-HPPC test. Unfortunately, the GDR cell electrodes had remained in an unsealed glove box for a little less than a year prior to assembly, and were made in various lots which yielded different beginning-of-life capacities. As a result, the cells had a large manufacturing variability with erratic behavior and analysis results were inconclusive. However, some general observations can still be made based on these test results.

Like the ATD Gen 2 Baseline and Variant C cells, the GDR cells showed the most performance degradation between characterization and four weeks, and this may be due to incomplete cell formation. The most obvious stress factor for the GDR cells was SOC, with some minor impact with test temperature. Power ratio and throughput had essentially no impact on performance degradation. Unlike the Gen 2 Baseline and Variant C cells, the GDR calendar-life cells aged more rapidly than the cycle-life cells. The GDR cell calendar-life consisted of resting at OCV for four weeks whereas the Baseline and Variant $\mathrm{C}$ cells were voltage clamped with a pulse per day. This difference may be a significant source of the difference, but other sources may include the mixture of lot numbers and high manufacturing variability. Likewise, the supplemental path dependence and RPT studies were inconclusive due to rapid degradation and inconsistent behavior.

Although the MPPC test was designed to be a less obtrusive test, the discontinuity in the cycle-life pulse resistance after the reference performance test was sill present. In fact, the discontinuity for the cells aged at $\mathrm{SOC}_{\mathrm{MAX}}$ was almost as much as was seen with the Gen 2 Baseline cell testing with a full $\mathrm{C}_{1} / 1$ and L-HPPC test. Although this could be a function of the MPPC test, it is also possible that the GDR cell variability contributed to this phenomenon as well. Furthermore, the null hypothesis that the ASIs determined from the MPPC and the L-HPPC yield statistically similar results was rejected based on the t-statistic methodology provided in the TLVT Manual. Similar observations were also made with

other, commercially available cells. This indicates that the MPPC test requires more scrutiny before it is implemented as the default RPT for life prediction. 


\section{REFERENCES}

1. Tien Q. Duong et al., "Energy Storage Research \& Development: FY 2004 Annual Progress Report," U.S. DOE FCVT, January 2005.

2. J. P. Christophersen, I. Bloom, E. V. Thomas, K. L. Gering, G. L. Henriksen, V. S. Battaglia, and D. Howell, "Advanced Technology Development For Lithium-Ion Batteries: Gen 2 Performance Evaluation Final Report," INL/EXT-05-00913, July 2006.

3. Gary Henriksen, “ATD Program Background and Introduction,” ATD Merit Review presentation, Argonne, IL, June 2004.

4. Advanced Technology Development Program For Lithium-Ion Batteries: Battery Technology Life Verification Test Manual, INEEL/EXT-04-01986, February 2005.

5. FreedomCAR Test Plan for Advanced Technology Development Gen 2 GDR Cells, EHV-TP-152, Revision 3, July 2004.

6. FreedomCAR Battery Test Manual for Power-Assist Hybrid Electric Vehicles, DOE/ID-11069, October 2003.

7. Efron, B., and Tibshirani, R. J., An Introduction to the Bootstrap, New York: Chapman and Hall, 1993.

8. J. P. Christophersen, C. D. Ho, C. G. Motloch, D. Howell, and H. Hess, "Effects of Reference Performance Testing during Aging Using Commercial Lithium-Ion Cells," J. Electrochem Soc., 153 A1406-A1416 (2006).

9. Uncertainty Study of INEEL EST Laboratory Battery Testing Systems Volume 1: Background and Derivation of Uncertainty Relationships, INEEL/EXT-01-00505. December 2001.

10. Uncertainty Study of INEEL EST Laboratory Battery Testing Systems Volume 2: Application of Results to INEEL Testers, INEEL/EXT-01-00505. March 2003. 


\section{Appendix A:}

Gen 2 GDR Receipt Inspection 


\section{A. GEN 2 GDR RECEIPT INSPECTION}

The measured cell weights, OCVs, and impedance measurements at $1 \mathrm{kHz}$ measured during the INL receipt inspection are shown in Tables A.1 (core-life cell matrix) and A.2 (supplemental-life cell matrix).

Table A.1. Gen 2 GDR cell receipt inspection for core-life cells.

\begin{tabular}{|c|c|c|c|c|c|c|c|}
\hline & \multirow{2}{*}{ Cell Group } & \multirow{2}{*}{$\begin{array}{c}\text { INL } \\
\text { Cell \# }\end{array}$} & \multirow{2}{*}{$\begin{array}{c}\text { Quallion Lot } \\
\text { Number }\end{array}$} & \multirow{2}{*}{$\begin{array}{c}\text { Weight } \\
(\mathrm{g})\end{array}$} & \multirow{2}{*}{$\begin{array}{c}\mathrm{OCV} \\
(\mathrm{V}) \\
\end{array}$} & \multicolumn{2}{|c|}{ AC Impedance } \\
\hline & & & & & & Real & Imaginary \\
\hline \multirow{16}{*}{ 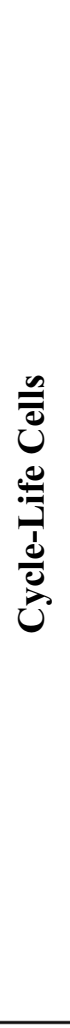 } & 40540 & 112 & F03E916 - 43 & 38.419 & 3.68 & 11.421 & -0.853 \\
\hline & 40540 & 120 & F03E916 - 55 & 38.215 & 3.70 & 11.582 & -0.938 \\
\hline & 40940 & 107 & F03E916 - 32 & 38.407 & 3.69 & 10.848 & -0.321 \\
\hline & 40940 & 111 & F03E916 - 42 & 38.516 & 3.69 & 11.333 & -0.821 \\
\hline & 80540 & 110 & F03E916 - 37 & 38.760 & 3.70 & 11.378 & -1.397 \\
\hline & 80540 & 117 & F03E916 - 50 & 38.288 & 3.70 & 11.173 & -0.861 \\
\hline & 80940 & 106 & F03E916 - 35 & 38.675 & 3.70 & 11.404 & -1.111 \\
\hline & 80940 & 116 & F03E916 - 49 & 38.222 & 3.70 & 11.088 & -0.799 \\
\hline & 40550 & 103 & F03E916 - 11 & 38.705 & 3.67 & 11.348 & -0.532 \\
\hline & 40550 & 113 & F03E916 - 46 & 38.545 & 3.70 & 10.813 & -0.978 \\
\hline & 40950 & 104 & F03E916 - 12 & 39.377 & 3.68 & 10.917 & -0.872 \\
\hline & 40950 & 119 & F03E916 - 54 & 38.435 & 3.69 & 11.422 & -0.682 \\
\hline & 80550 & 102 & F03E916 - 9 & 38.833 & 3.70 & 10.860 & -0.696 \\
\hline & 80550 & 115 & F03E916 - 48 & 38.195 & 3.70 & 10.854 & -0.932 \\
\hline & 80950 & 105 & F03E916 - 21 & 38.594 & 3.69 & 11.197 & -0.801 \\
\hline & 80950 & 108 & F03E916 - 33 & 38.296 & 3.69 & 11.003 & 0.150 \\
\hline \multirow{6}{*}{ 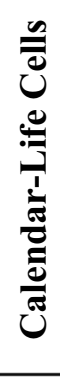 } & $80 \mathrm{C} 40$ & 130 & F04D151- 03 & 38.264 & 3.64 & 9.179 & 1.837 \\
\hline & $80 \mathrm{C} 40$ & 135 & F04D151 - 38 & 38.529 & 3.66 & 10.031 & 1.678 \\
\hline & $80 \mathrm{C} 50$ & 131 & F04D151- 06 & 38.321 & 3.66 & 9.702 & 1.746 \\
\hline & $80 \mathrm{C} 50$ & 132 & F04D151 - 11 & 38.676 & 3.66 & 9.545 & 1.733 \\
\hline & $80 \mathrm{C} 60$ & 133 & F04D151 - 14 & 38.634 & 3.66 & 10.239 & 1.690 \\
\hline & $80 \mathrm{C} 60$ & 134 & F04D151 - 15 & 38.493 & 3.66 & 9.992 & 1.834 \\
\hline \multicolumn{4}{|c|}{ Average } & 38.52 & 3.68 & 10.788 & -0.088 \\
\hline \multicolumn{4}{|c|}{ Standard Deviation } & 0.27 & 0.02 & 0.693 & 1.190 \\
\hline
\end{tabular}


Table A.2. Gen 2 GDR cell receipt inspection for supplemental-life cells.

\begin{tabular}{|c|c|c|c|c|c|c|c|}
\hline & \multirow{2}{*}{ Cell Group } & \multirow{2}{*}{$\begin{array}{l}\text { INL } \\
\text { Cell \# }\end{array}$} & \multirow{2}{*}{$\begin{array}{l}\text { Quallion Lot } \\
\text { Number }\end{array}$} & \multirow{2}{*}{$\begin{array}{l}\text { Weight } \\
(\mathrm{g})\end{array}$} & \multirow{2}{*}{$\begin{array}{l}\mathrm{OCV} \\
(\mathrm{V})\end{array}$} & \multicolumn{2}{|c|}{ AC Impedance } \\
\hline & & & & & & Real & Imaginary \\
\hline \multirow{7}{*}{ 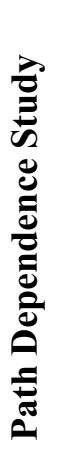 } & $40 \mathrm{C} 540$ & 101 & F03E916 - 8 & 38.571 & 3.68 & 10.883 & -0.733 \\
\hline & $40 \mathrm{C} 540$ & 121 & F04A914 - 3 & 38.794 & 3.70 & 11.280 & -0.765 \\
\hline & $80 \mathrm{C} 950$ & 109 & F03E916 - 24 & 38.340 & 3.69 & 11.043 & -0.674 \\
\hline & $80 C 950$ & 118 & F03E916 - 52 & 38.541 & 3.69 & 11.491 & -0.906 \\
\hline & $405 \mathrm{C} 40$ & 114 & F03E916 - 47 & 39.052 & 3.68 & 11.290 & -0.854 \\
\hline & $405 \mathrm{C} 40$ & 125 & F04A914 - 8 & 38.723 & 3.71 & 11.160 & -0.599 \\
\hline & $809 \mathrm{C} 50$ & 136 & F04D151 - 18 & 38.392 & 3.67 & 10.316 & 1.784 \\
\hline \multirow{7}{*}{ 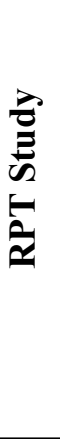 } & $809 C 50$ & 137 & F04D151 - 29 & 38.450 & 3.66 & 10.375 & 1.776 \\
\hline & 40540 & 127 & F04A908 - 8 & 38.708 & 3.70 & 11.523 & -0.939 \\
\hline & 40540 & 128 & F04A908 - 9 & 38.532 & 3.70 & 11.994 & -0.964 \\
\hline & 80950 & 123 & F04A914 - 6 & 38.725 & 3.70 & 11.507 & -0.948 \\
\hline & 80950 & 138 & F04D151 - 40 & 38.485 & 3.66 & 9.237 & 0.851 \\
\hline & \multicolumn{3}{|c|}{ Average } & 38.60 & 3.69 & 11.105 & -0.408 \\
\hline & \multicolumn{3}{|c|}{ Standard Deviation } & 0.18 & 0.02 & 0.674 & 0.958 \\
\hline
\end{tabular}


Appendix B:

Individual Cell Results 


\section{B. INDIVIDUAL CELL RESULTS}

This appendix details the discharge capacity and ASI at $\mathrm{SOC}_{\mathrm{MAX}}$ and $\mathrm{SOC}_{\mathrm{MIN}}$ (both calculated and temperature compensated) for each ATD Gen 2 GDR cell. The first column describes the test group (i.e., the SOC, life-test profile, and test temperature). The second column shows the laboratory-specific cell number and the third column shows the ATD label (see Section B.1 for the structure of the ATD label). The remaining columns provide the cell-specific data at each four-week increment starting from BOL (i.e., characterization) through 36 weeks. The last column shows the percent-fade in cell degradation, normalized to the characterization RPT. The cell label and percent-fade (or growth) from beginning of life either has a blue or green background. A green background indicates that the cell was removed from test earlier in life, and a gray background indicates that no data are expected. The yellow background is for averages (upper row) and standard deviations (lower row). The averages and standard deviations are only calculated using the cells with a blue background in the fade column.

\section{B.1 Cell Labeling Structure}

An ATD labeling structure was established to provide the diagnostic laboratories with succinct information regarding the end-of-test status of the test cells. It is in the form of G2[X].AABCC.DEEE.TT.CF.AG.Z.S, where:

\begin{tabular}{|c|c|c|}
\hline $\mathrm{G} 2[\mathrm{X}]$ & $=$ & Gen 2 cell, and $[X]=G$ or V (V is for all cells with VEC electrolyte) \\
\hline AA & $=$ & Test Matrix State of Charge \\
\hline B & $=$ & $\begin{array}{l}\text { Test Matrix profile, e.g., } \mathrm{S}, \mathrm{N} \text {, and } \mathrm{C} \text {, where } \mathrm{S}=\text { in storage, } \mathrm{N}=\text { no aging, and } \mathrm{C}= \\
\text { calendar life cell. If cycle-life testing, use " } 5 \text { " for the } 95^{\text {th }} \text { Percentile profile, and " } 9 \text { " } \\
\text { for the } 99^{\text {th }} \text { Percentile Profile. }\end{array}$ \\
\hline $\mathrm{CC}$ & $=$ & Test Matrix Temperature, $\left({ }^{\circ} \mathrm{C}\right)$ \\
\hline D & $=$ & Original DOE Laboratory, A = ANL; B = BNL; I = INEEL; L = LBNL \\
\hline EEE & $=$ & Sequential cell number assigned by National Laboratory (INL $=101$ through $1 \mathrm{XX}$ ). \\
\hline TT & $=$ & Time at life testing (weeks), Characterization testing is labeled as "CC". \\
\hline $\mathrm{CF}$ & $=$ & $\begin{array}{l}\text { Capacity Fade relative to RPT0. For the MPPC, capacity fade is based on the } \mathrm{C}_{1} / 1 \\
\text { discharge between } \mathrm{SOC}_{\mathrm{MAX}} \text { and } \mathrm{SOC}_{\mathrm{MIN}} \text {. For the L-HPPC test, it is based on the } \\
\text { full } \mathrm{C}_{1} / 1 \text { discharge from } 100 \% \text { SOC. Characterization data are labeled as " } 00 \text { ". }\end{array}$ \\
\hline $\mathrm{AG}$ & $=$ & ASI Growth at $\mathrm{SOC}_{\mathrm{MAX}}$ relative to RPT0. Characterization data are labeled " 00 ". \\
\hline Z & $=$ & $\begin{array}{l}\text { Abnormal condition flag: } \mathrm{S}=\text { shorted; } \mathrm{V}=\text { vented; } \mathrm{P}=\text { punctured; } \mathrm{L}=\text { leaked; } \mathrm{T}= \\
\text { tab problem; } \mathrm{G}=\text { Good. }\end{array}$ \\
\hline $\mathrm{S}[\mathrm{S}]$ & $=$ & $\begin{array}{l}\text { Status: } \mathrm{T}=\text { test continuing; } \mathrm{F}=\text { finished testing and in storage. Or if shipped to } \\
\text { another laboratory then, } \mathrm{A}=\text { shipped to } \mathrm{ANL} ; \mathrm{B}=\text { shipped to } \mathrm{BNL} ; \mathrm{L}=\text { shipped to } \\
\text { LBNL. }[\mathrm{S}]=\text { additional status flags as appropriate to track the history of the cell. }\end{array}$ \\
\hline
\end{tabular}

The label begins with either G2G for the GDR-only cells, or G2V for the GDR+VEC cells. The test matrix SOC, profile, and temperature (i.e., AABCC) identify the type of test, where cycle-life (5 or 9), or calendar-life (C) testing is performed at a designated SOC and temperature. Next, the original DOE laboratory is identified, along with the laboratory-specific cell number. The testing laboratories established a sequential numbering scheme such that all INL cells are numbered between 100 and 200. The time at life testing (i.e., TT) shows the number of weeks the cell has been aging in four-week increments. This is followed by the total capacity fade (CF) and ASI growth at $\operatorname{SOC}_{\mathrm{MAX}}(\mathrm{AG})$ at that RPT. The abnormal condition flag identifies any problems, such as shorting (S), venting (V), leaking (L), puncturing $(\mathrm{P})$, or damaged $\operatorname{tab}(\mathrm{s})(\mathrm{T})$. Otherwise, the cell is marked good $(\mathrm{G})$. The status flag either shows that the cell is still on test $(\mathrm{T})$, has finished testing $(\mathrm{F})$, or has been sent to a diagnostic laboratory (e.g., A, L, or B). 
For example, G2G.40550.I113.36.07.10.G.F is INL Cell 113. It was cycle-life tested using the $95^{\text {th }}$ Pecentile profile at $40 \% \mathrm{SOC}\left(\mathrm{SOC}_{\mathrm{MIN}}\right)$ and $50^{\circ} \mathrm{C}$ for 36 weeks before being taken off test with a discharge capacity fade (between $\mathrm{SOC}_{\mathrm{MAX}}$ and $\mathrm{SOC}_{\mathrm{MIN}}$ ) of $7 \%$, and an ASI growth of $10 \%$ at $\mathrm{SOC}_{\mathrm{MAX}}$. The cell was in good condition when it was removed from test, and is currently in storage at INL.

\section{B.2 Core-Life Test Data}

\subsubsection{Cycle-Life Data}

Table B.1. Cycle-life $\mathrm{C}_{1} / 1$ discharge capacity between $\mathrm{SOC}_{\mathrm{MAX}}$ and $\mathrm{SOC}_{\mathrm{MIN}}$.

\begin{tabular}{|c|c|c|c|c|c|c|c|c|c|c|c|c|c|}
\hline \multicolumn{3}{|c|}{ Core Matrix } & \multirow{2}{*}{\multicolumn{11}{|c|}{$\mathrm{C}_{1} / 1$ Discharge Capacity Between $\mathrm{SOC}_{\mathrm{MAX}}$ and $\mathrm{SOC}_{\mathrm{MIN}}$}} \\
\hline \multicolumn{3}{|c|}{ Cycle-Life Cells } & & & & & & & & & & & \\
\hline \multirow{2}{*}{$\begin{array}{c}\text { Test } \\
\text { Group }\end{array}$} & \multirow[t]{2}{*}{ Cell \# } & \multirow[t]{2}{*}{ ATD Label } & & & & & & & & & & & \\
\hline & & & Char & $4 \mathrm{wk}$ & $8 \mathrm{wk}$ & $12 \mathrm{wk}$ & $16 \mathrm{wk}$ & $20 \mathrm{wk}$ & $24 \mathrm{wk}$ & $28 \mathrm{wk}$ & $32 \mathrm{wk}$ & $36 \mathrm{wk}$ & fade \\
\hline $\mathrm{AABCC}$ & & & & & & & & & & & & & \\
\hline$\left(\mathrm{SOC} / \mathrm{B} /{ }^{\circ} \mathrm{C}\right)$ & & & $(\mathrm{Ah})$ & $(\mathrm{Ah})$ & $(\mathrm{Ah})$ & (Ah) & (Ah) & (Ah) & (Ah) & $(\mathrm{Ah})$ & (Ah) & $(\mathrm{Ah})$ & $(\%)$ \\
\hline & & & 0.353 & 0.335 & 0.328 & 0.331 & 0.327 & 0.323 & 0.326 & 0.325 & 0.324 & 0.323 & $8.54 \%$ \\
\hline & & & 0.004 & 0.004 & 0.019 & 0.005 & 0.006 & 0.021 & 0.006 & 0.007 & 0.007 & 0.007 & $1.46 \%$ \\
\hline 40540 & 112 & G2G.40540.I112.36.07.11.G.F & 0.354 & 0.337 & 0.335 & 0.333 & 0.324 & 0.332 & 0.330 & 0.329 & 0.329 & 0.328 & $7.39 \%$ \\
\hline 40540 & 120 & G2G.40540.I120.36.06.06.G.F & 0.351 & 0.340 & 0.340 & 0.336 & 0.329 & 0.335 & 0.332 & 0.331 & 0.331 & 0.329 & $6.21 \%$ \\
\hline 40940 & 107 & G2G.40940.1107.36.07.08.G.F & 0.357 & 0.341 & 0.338 & 0.340 & 0.337 & 0.336 & 0.335 & 0.335 & 0.333 & 0.333 & $6.80 \%$ \\
\hline 40940 & 111 & 2G.40940.1111.36.07.07.G.F & 0.360 & 0.342 & 0.339 & 0.341 & 0.335 & 0.338 & 0.335 & 0.333 & 0.334 & 0.333 & $7.43 \%$ \\
\hline 80540 & 110 & G2G.80540.1110.36.09.18.G.F & 0.353 & 0.333 & 0.331 & 0.329 & 0.324 & 0.325 & 0.325 & 0.324 & 0.323 & 0.322 & $8.61 \%$ \\
\hline 80540 & 117 & 540.I117.36.08.15.G.F & 0.355 & 0.336 & 0.334 & 0.331 & 0.330 & 0.330 & 0.329 & 0.328 & 0.327 & 0.326 & $8.13 \%$ \\
\hline 80940 & 106 & G2G.80940.1106.36.09.17.G.F & 0.356 & 0.334 & 0.332 & 0.331 & 0.327 & 0.329 & 0.328 & 0.326 & 0.325 & 0.324 & $8.92 \%$ \\
\hline 80940 & 116 & G2G.80940.I116.28.07.13.G.F & 0.351 & 0.336 & 0.260 & 0.331 & 0.315 & 0.249 & 0.328 & & & & $6.71 \%$ \\
\hline 40550 & 103 & $36.08 .11 . G . F$ & 0.354 & 0.339 & 0.337 & 0.335 & 0.332 & 0.331 & 0.327 & 0.327 & 0.326 & 0.325 & $8.17 \%$ \\
\hline 40550 & 113 & G2G.40550.1113.36.07.10.G.F & 0.346 & 0.333 & 0.330 & 0.328 & 0.327 & 0.325 & 0.323 & 0.323 & 0.322 & 0.321 & $7.29 \%$ \\
\hline 40950 & 104 & G2G.40950.I104.36.09.11.G.F & 0.355 & 0.338 & 0.335 & 0.334 & 0.332 & 0.330 & 0.327 & 0.327 & 0.326 & 0.324 & $8.69 \%$ \\
\hline 40950 & 119 & G2G.40950.1119.36.08.11.G.F & 0.347 & 0.330 & 0.328 & 0.326 & 0.324 & 0.323 & 0.321 & 0.321 & 0.320 & 0.319 & $8.19 \%$ \\
\hline 80550 & 102 & G2G.80550.I102.36.10.21.G.F & 0.353 & 0.333 & 0.330 & 0.328 & 0.326 & 0.324 & 0.321 & 0.320 & 0.318 & 0.317 & $10.39 \%$ \\
\hline 80550 & 115 & G2G.80550.1115.36.10.15.G.F & 0.345 & 0.327 & 0.326 & 0.323 & 0.321 & 0.319 & 0.316 & 0.313 & 0.312 & 0.310 & $10.34 \%$ \\
\hline 80950 & 105 & G2G.80950.I105.36.10.21.G.F & 0.356 & 0.334 & 0.331 & 0.330 & 0.328 & 0.325 & 0.322 & 0.321 & 0.320 & 0.318 & $10.49 \%$ \\
\hline 80950 & 108 & G2G.80950.I108.36.11.21.G.F & 0.346 & 0.328 & 0.325 & 0.321 & 0.319 & 0.317 & 0.313 & 0.311 & 0.309 & 0.308 & $11.00 \%$ \\
\hline
\end{tabular}

Table B.2. Cycle-life discharge ASI at $\mathrm{SOC}_{\mathrm{MAX}}$ and $30^{\circ} \mathrm{C}$.

\begin{tabular}{|c|c|c|c|c|c|c|c|c|c|c|c|c|c|}
\hline \multicolumn{3}{|c|}{ Core Matrix } & \multirow{2}{*}{\multicolumn{11}{|c|}{$30^{\circ} \mathrm{C}$ Discharge $\mathrm{ASI}$ at $\mathrm{SOC}_{\mathrm{MAX}}$}} \\
\hline \multicolumn{3}{|c|}{ Cycle-Life Cells } & & & & & & & & & & & \\
\hline \multirow{2}{*}{$\begin{array}{l}\text { Test } \\
\text { Group }\end{array}$} & \multirow[t]{2}{*}{ Cell \# } & \multirow[t]{2}{*}{ ATD Label } & & & & & & & & & & & \\
\hline & & & Char & $4 \mathrm{wk}$ & $8 \mathrm{wk}$ & $12 \mathrm{wk}$ & $16 \mathrm{wk}$ & $20 \mathrm{wk}$ & $24 \mathrm{wk}$ & $28 \mathrm{wk}$ & $32 \mathrm{wk}$ & $36 \mathrm{wk}$ & fade \\
\hline \multicolumn{14}{|l|}{$\mathrm{AABCC}$} \\
\hline \multirow[t]{3}{*}{$\left(\mathrm{SOC} / \mathrm{B} /{ }^{\circ} \mathrm{C}\right)$} & & & $\left(\Omega-\mathrm{cm}^{2}\right)$ & $\left(\Omega-\mathrm{cm}^{2}\right.$ & $\left(\Omega-\mathrm{cm}^{2}\right.$ & $\left(\Omega-\mathrm{cm}^{2}\right)$ & $\left(\Omega-\mathrm{cm}^{2}\right)$ & $\left(\Omega-\mathrm{cm}^{2}\right)$ & $\left(\Omega-\mathrm{cm}^{2}\right)$ & $\left(\Omega-\mathrm{cm}^{2}\right)$ & $\left(\Omega-\mathrm{cm}^{2}\right)$ & $\left(\Omega-\mathrm{cm}^{2}\right)$ & $(\%)$ \\
\hline & & & 23.63 & 24.16 & 24.63 & 25.37 & 25.77 & 25.84 & 26.42 & 26.44 & 26.93 & 26.84 & $13.55 \%$ \\
\hline & & & 0.55 & 1.54 & 1.54 & 1.66 & 1.76 & 1.80 & 1.75 & 1.77 & 1.86 & 1.70 & $5.26 \%$ \\
\hline 40540 & 112 & $G F$ & 2320 & 323 & 2394 & 2462 & 2477 & 2466 & 2509 & 2537 & 2568 & 2573 & $1090 \%$ \\
\hline 40540 & 120 & G2G.40540.1120.36.06.06.G.F & $\frac{20.20}{22.62}$ & 21.53 & $\frac{2.04}{21.91}$ & $\frac{24.02}{22.27}$ & $\frac{24.11}{22.66}$ & $\frac{24.00}{22.95}$ & $\frac{20.05}{23.20}$ & $\frac{2.01}{23.20}$ & $\frac{2.00}{24.22}$ & $\frac{2.10}{24.03}$ & $6.21 \%$ \\
\hline 40940 & 107 & G2G.40940.1107.36.07.08.G.F & 22.97 & 22.35 & 22.95 & 23.37 & 23.61 & 23.59 & 24.13 & 24.38 & 24.74 & 24.77 & $7.81 \%$ \\
\hline 40940 & 111 & G2G.40940.1111.36.07.07.G.F & 23.34 & 22.40 & 23.07 & 23.59 & 23.67 & 23.53 & 24.25 & 24.71 & 24.71 & 24.93 & $6.83 \%$ \\
\hline 80540 & 110 & G2G.80540.1110.36.09.18.G.F & 24.12 & 25.23 & 26.04 & 26.80 & 27.33 & 27.52 & 27.62 & 27.60 & 28.81 & 28.52 & $18.24 \%$ \\
\hline 80540 & 117 & G.F & 24.17 & 24.88 & 25.63 & 26.44 & 26.94 & 27.02 & 27.38 & 27.17 & 28.42 & 27.87 & $15.32 \%$ \\
\hline 80940 & 106 & G2G.80940.I106.36.09.17.G.F & 24.47 & 26.31 & 26.44 & 27.11 & 27.82 & 27.91 & 28.21 & 28.12 & 29.03 & 28.65 & $17.07 \%$ \\
\hline 80940 & 116 & G2G.80940.1116.28.07.13.G.F & 23.82 & 25.10 & 23.59 & 25.65 & 26.61 & 25.13 & 27.03 & & & & $13.49 \%$ \\
\hline 40550 & 103 & G2G.40550.1103 & 22.76 & 22.12 & 22.73 & 23.37 & 23.75 & 24.06 & 24.88 & 24.87 & 25.15 & 25.21 & $10.76 \%$ \\
\hline 40550 & 113 & G2G.40550.1113.36.07.10.G.F & 23.86 & 23.64 & 24.40 & 24.88 & 25.21 & 25.53 & 25.96 & 25.86 & 26.01 & 26.15 & $9.58 \%$ \\
\hline 40950 & 104 & G2G.40950.1104.36.09.11.G.F & 23.32 & 22.87 & 23.50 & 24.05 & 24.41 & 24.63 & 25.52 & 25.39 & 25.68 & 25.97 & $11.39 \%$ \\
\hline 40950 & 119 & G2G.40950.I119.36.08.11.G.F & 23.94 & 24.55 & 25.05 & 25.41 & 25.65 & 25.79 & 26.25 & 26.21 & 26.37 & 26.50 & $10.69 \%$ \\
\hline 80550 & 102 & G2G.80550.I102.36.10.21.G.F & 23.68 & 25.57 & 26.30 & 27.21 & 27.71 & 27.98 & 28.59 & 28.70 & 28.92 & 28.77 & $21.49 \%$ \\
\hline 80550 & 115 & G2G.80550.1115.36.10.15.G.F & 24.33 & 25.67 & 26.39 & 26.88 & 27.14 & 27.36 & 27.87 & 27.93 & 28.23 & 27.99 & $15.04 \%$ \\
\hline 80950 & 105 & G2G.80950.I105.36.10.21.G.F & 23.72 & 25.42 & 25.95 & 27.08 & 27.57 & 27.99 & 28.48 & 28.62 & 29.07 & 28.76 & $21.23 \%$ \\
\hline 80950 & 108 & G2G.80950.I108.36.11.21.G.F & 23.80 & 25.69 & 26.15 & 27.18 & 27.41 & 27.72 & 28.25 & 28.49 & 28.87 & 28.71 & $20.63 \%$ \\
\hline
\end{tabular}


Table B.3. Cycle-life temperature-compensated discharge ASI at $\mathrm{SOC}_{\mathrm{MAX}}$ and $30^{\circ} \mathrm{C}$.

\begin{tabular}{|c|c|c|c|c|c|c|c|c|c|c|c|c|c|}
\hline \multicolumn{3}{|c|}{ Core Matrix } & \multirow{2}{*}{\multicolumn{11}{|c|}{ Temperature Compensated $30^{\circ} \mathrm{C}$ Discharge ASI at $\mathrm{SOC}_{\mathrm{MAX}}$}} \\
\hline \multicolumn{3}{|c|}{ Cycle-Life Cells } & & & & & & & & & & & \\
\hline \multirow{2}{*}{$\begin{array}{l}\text { Test } \\
\text { Group }\end{array}$} & \multirow[t]{2}{*}{ Cell \# } & \multirow[t]{2}{*}{ ATD Label } & & & & & & & & & & & \\
\hline & & & Char & $4 \mathrm{wk}$ & $8 \mathrm{wk}$ & $12 \mathrm{wk}$ & $16 \mathrm{wk}$ & $20 \mathrm{wk}$ & $24 \mathrm{wk}$ & $28 \mathrm{wk}$ & $32 \mathrm{wk}$ & $36 \mathrm{wk}$ & fade \\
\hline \multicolumn{14}{|l|}{$A A B C C$} \\
\hline \multirow[t]{3}{*}{$\left(\mathrm{SOC} / \mathrm{B} /{ }^{\circ} \mathrm{C}\right)$} & & & $\left(\Omega-\mathrm{cm}^{2}\right)$ & $\left(\Omega-\mathrm{cm}^{2}\right.$ & $\left(\Omega-\mathrm{cm}^{2}\right.$ & $\left(\Omega-\mathrm{cm}^{2}\right.$ & $\left(\Omega-\mathrm{cm}^{2}\right.$ & $\overline{\left(\Omega-\mathrm{cm}^{2}\right)}$ & $\left(\Omega-\mathrm{cm}^{2}\right)$ & $\overline{\left(\Omega-\mathrm{cm}^{2}\right)}$ & $\left(\Omega-\mathrm{cm}^{2}\right.$ & $\left(\Omega-\mathrm{cm}^{2}\right)$ & $(\%)$ \\
\hline & & & 24.10 & 24.39 & 24.83 & 25.63 & 25.95 & 26.01 & 26.66 & 26.72 & 26.96 & 27.03 & $12.51 \%$ \\
\hline & & & 0.67 & 1.65 & 1.57 & 1.73 & 1.79 & & 1.79 & 1.78 & 1.95 & 1.73 & $5.26 \%$ \\
\hline & & & & & & & & & & & & & \\
\hline 40540 & 112 & 32G.40540.I112.36.07.11.G.F & 24.05 & 23.82 & 24.31 & 25.09 & 25.03 & 25.02 & 25.51 & 25.80 & 25.69 & 26.21 & $9.01 \%$ \\
\hline 40540 & 120 & G2G.40540.I120.36.06.06.G.F & 22.90 & 21.36 & 21.88 & 22.23 & 22.68 & 22.98 & 23.28 & 23.48 & 23.90 & 24.03 & $4.95 \%$ \\
\hline 40940 & 107 & G2G.40940.1107.36.07.08.G.F & 23.24 & 22.42 & 23.04 & 23.27 & 23.54 & 23.67 & 24.13 & 24.54 & 24.29 & 24.72 & $6.36 \%$ \\
\hline 40940 & 111 & 40.I111.36.07.07.G.F & 23.72 & 22.31 & 23.19 & 23.87 & 23.96 & 23.73 & 24.52 & 25.15 & 24.60 & 25.21 & $6.27 \%$ \\
\hline 80540 & 110 & G2G.80540.I110.36.09.18.G.F & 24.76 & 25.54 & 26.24 & 27.04 & 27.55 & 27.72 & 27.98 & 28.01 & 28.74 & 28.83 & $16.43 \%$ \\
\hline 80540 & 117 & G2G.80540.1117.36.08.15.G.F & 24.25 & 24.57 & 25.58 & 26.47 & 26.96 & 26.99 & 27.32 & 27.31 & 27.91 & 27.87 & $14.90 \%$ \\
\hline 80940 & 106 & G.F & 24.63 & 26.24 & 26.34 & 27.09 & 27.77 & 27.90 & 28.20 & 28.30 & 28.49 & 28.58 & $16.07 \%$ \\
\hline 80940 & 116 & G2G.80940.1116.28.07.13.G.F & 25.55 & 26.18 & 23.89 & 26.17 & 26.99 & 25.37 & 27.46 & & & & $7.48 \%$ \\
\hline 40550 & 103 & G2G.40550.1103.36.08.11.G.F & 23.15 & 22.39 & 23.03 & 23.70 & 23.99 & 24.34 & 25.18 & 25.13 & 25.45 & 25.45 & $9.94 \%$ \\
\hline 40550 & 113 & 07.10. G.F & 24.28 & 23.89 & 24.67 & 25.16 & 25.41 & 25.68 & 26.20 & 26.06 & 26.28 & 26.33 & $8.46 \%$ \\
\hline 40950 & 104 & G2G.40950.1104.36.09.11.G.F & 23.66 & 23.13 & 23.80 & 24.37 & 24.64 & 24.84 & 25.80 & 25.64 & 25.94 & 26.21 & $10.77 \%$ \\
\hline 40950 & 119 & G2G.40950.I119.36.08.11.G.F & 24.21 & 24.72 & 25.24 & 25.65 & 25.75 & 25.88 & 26.40 & 26.31 & 26.46 & 26.62 & $9.94 \%$ \\
\hline 80550 & 102 & & 24.04 & 25.81 & 26.57 & 27.55 & 27.95 & 28.16 & 28.86 & 28.99 & 29.13 & 28.97 & $20.50 \%$ \\
\hline 80550 & 115 & G2G.80550.1115.36.10.15.G.F & 24.82 & 26.07 & 26.78 & 27.34 & 27.47 & 27.70 & 28.31 & 28.37 & 28.81 & 28.38 & $14.35 \%$ \\
\hline 80950 & 105 & G2G.80950.I105.36.10.21.G.F & 24.17 & 25.75 & 26.31 & 27.49 & 27.89 & 28.30 & 28.86 & 29.00 & 29.42 & 29.02 & $20.07 \%$ \\
\hline 80950 & 108 & G2G.80950.I108.36.11.21.G.F & 24.21 & 26.00 & 26.48 & 27.56 & 27.66 & 27.92 & 28.60 & 28.76 & 29.22 & 28.97 & $19.65 \%$ \\
\hline
\end{tabular}

Table B.4. Cycle-life discharge ASI at $\mathrm{SOC}_{\mathrm{MIN}}$ and $30^{\circ} \mathrm{C}$.

\begin{tabular}{|c|c|c|c|c|c|c|c|c|c|c|c|c|c|}
\hline \multicolumn{3}{|c|}{ Core Matrix } & \multirow{2}{*}{\multicolumn{11}{|c|}{$30^{\circ} \mathrm{C}$ Discharge $\mathrm{ASI}$ at $\mathrm{SOC}_{\mathrm{MIN}}$}} \\
\hline \multicolumn{3}{|c|}{ Cycle-Life Cells } & & & & & & & & & & & \\
\hline \multirow{2}{*}{$\begin{array}{c}\text { Test } \\
\text { Group } \\
\end{array}$} & \multirow[t]{2}{*}{ Cell \# } & \multirow[t]{2}{*}{ ATD Label } & & & & & & & & & & & \\
\hline & & & Char & $4 \mathrm{wk}$ & $8 \mathrm{wk}$ & $12 \mathrm{wk}$ & $16 \mathrm{wk}$ & $20 \mathrm{wk}$ & $24 \mathrm{wk}$ & $28 \mathrm{wk}$ & $32 \mathrm{wk}$ & $36 \mathrm{wk}$ & fade \\
\hline \multicolumn{14}{|l|}{ AABCC } \\
\hline \multirow[t]{3}{*}{$\left(\mathrm{SOC} / \mathrm{B} /{ }^{\circ} \mathrm{C}\right)$} & & & $\left(\Omega-\mathrm{cm}^{2}\right)$ & $\left(\Omega-\mathrm{cm}^{2}\right)$ & $\left(\Omega-\mathrm{cm}^{2}\right.$ & $\left(\Omega-\mathrm{cm}^{2}\right)$ & $\left(\Omega-\mathrm{cm}^{2}\right.$ & $\left(\Omega-\mathrm{cm}^{2}\right)$ & $\left(\Omega-\mathrm{cm}^{2}\right)$ & $\left(\Omega-\mathrm{cm}^{2}\right)$ & $\left(\Omega-\mathrm{cm}^{2}\right)$ & $\left(\Omega-\mathrm{cm}^{2}\right)$ & $(\%)$ \\
\hline & & & 21.24 & 23.52 & 24.28 & 24.60 & 25.18 & 25.39 & 25.49 & 25.82 & 26.31 & 26.42 & $24.40 \%$ \\
\hline & & & 0.40 & 0.48 & 0.55 & 0.49 & 0.52 & 0.68 & 0.59 & 0.73 & 0.66 & 0.79 & $2.95 \%$ \\
\hline & & & & & & & & & & & & & \\
\hline 40540 & 112 & G2G.40540.1112.36.07.11.G.F & 21.03 & 23.34 & 23.89 & 24.27 & 24.79 & 24.77 & 24.83 & 25.07 & 25.79 & 25.60 & $21.71 \%$ \\
\hline 40540 & 120 & G2G.40540.1120.36.06.06.G.F & 20.51 & 22.54 & 23.23 & 23.65 & 24.22 & 24.14 & 24.41 & 24.52 & 25.23 & 24.99 & $21.86 \%$ \\
\hline 40940 & 107 & G2G.40940.1107.36.07.08.G.F & 20.78 & 22.88 & 23.50 & 23.94 & 24.42 & 24.35 & 24.60 & 24.66 & 25.27 & 25.18 & $21.16 \%$ \\
\hline 40940 & 111 & G2G.40940.1111.36.07.07.G.F & 21.22 & 23.20 & 23.89 & 24.22 & 24.83 & 24.74 & 24.99 & 25.08 & 25.65 & 25.55 & $20.37 \%$ \\
\hline 80540 & 110 & 9.18.G.F & 21.55 & 23.81 & 24.27 & 24.65 & 25.26 & 25.43 & 25.65 & 26.04 & 26.67 & 26.44 & $22.67 \%$ \\
\hline 80540 & 117 & G2G.80540.1117.36.08.15.G.F & 21.55 & 23.73 & 24.20 & 24.63 & 25.16 & 25.15 & 25.43 & 25.70 & 26.48 & 26.17 & $21.41 \%$ \\
\hline 80940 & 106 & G2G.80940.I106.36.09.17.G.F & 22.02 & 24.27 & 24.72 & 25.05 & 25.98 & 26.17 & 26.42 & 26.72 & 27.41 & 27.16 & $23.36 \%$ \\
\hline 80940 & 116 & & 21.30 & 23.50 & 25.13 & 24.38 & 25.34 & 26.47 & 25.46 & & & & $19.51 \%$ \\
\hline 40550 & 103 & G2G.40550.I103.36.08.11.G.F & 20.64 & 23.12 & 23.86 & 24.30 & 24.66 & 25.05 & 25.10 & 25.53 & 25.84 & 26.23 & $27.06 \%$ \\
\hline 40550 & 113 & G2G.40550.1113.36.07.10.G.F & 21.52 & 24.08 & 24.90 & 25.51 & 25.96 & 26.19 & 26.29 & 26.73 & 26.97 & 27.28 & $26.75 \%$ \\
\hline 40950 & 104 & & 21.05 & 23.49 & 24.24 & 24.55 & 24.99 & 25.38 & 25.46 & 25.93 & 26.31 & 26.61 & $26.39 \%$ \\
\hline 40950 & 119 & G2G.40950.I119.36.08.11.G.F & 21.66 & 24.37 & 25.18 & 25.47 & 25.94 & 26.18 & 26.15 & 26.61 & 27.00 & 27.20 & $25.62 \%$ \\
\hline 80550 & 102 & G2G.80550.1102.36.10.21.G.F & 21.17 & 23.39 & 24.16 & 24.55 & 25.23 & 25.31 & 25.62 & 25.95 & 26.42 & 26.77 & $26.48 \%$ \\
\hline 80550 & 115 & G2G.80550.1115.36.10.15.G.F & 21.50 & 23.75 & 24.66 & 24.85 & 25.20 & 25.38 & 25.51 & 25.82 & 26.06 & 26.58 & $23.60 \%$ \\
\hline 80950 & 105 & G2G.80950.I105.36.10.21.G.F & 21.04 & 23.51 & 24.25 & 24.85 & 25.59 & 25.94 & 26.15 & 26.69 & 26.99 & 27.48 & $30.64 \%$ \\
\hline 80950 & 108 & G2G.80950.1108.36.11.21.G.F & 21.30 & 23.37 & 24.36 & 24.75 & 25.29 & 25.56 & 25.76 & 26.26 & 26.61 & 27.03 & $26.88 \%$ \\
\hline
\end{tabular}


Table B.5. Cycle-life temperature-compensated discharge ASI at $\mathrm{SOC}_{\mathrm{MIN}}$ and $30^{\circ} \mathrm{C}$.

\begin{tabular}{|c|c|c|c|c|c|c|c|c|c|c|c|c|c|}
\hline \multicolumn{3}{|c|}{ Core Matrix } & \multirow{2}{*}{\multicolumn{11}{|c|}{ Temperature Compensated $30^{\circ} \mathrm{C}$ Discharge ASI at $\mathrm{SOC}_{\mathrm{MIN}}$}} \\
\hline \multicolumn{3}{|c|}{ Cycle-Life Cells } & & & & & & & & & & & \\
\hline \multirow{2}{*}{$\begin{array}{l}\text { Test } \\
\text { Group }\end{array}$} & \multirow[t]{2}{*}{ Cell \# } & \multirow[t]{2}{*}{ ATD Label } & & & & & & & & & & & \\
\hline & & & Char & $4 \mathrm{wk}$ & $8 \mathrm{wk}$ & $12 \mathrm{wk}$ & $16 \mathrm{wk}$ & $20 \mathrm{wk}$ & $24 \mathrm{wk}$ & $28 \mathrm{wk}$ & $32 \mathrm{wk}$ & $36 \mathrm{wk}$ & fade \\
\hline \multicolumn{14}{|l|}{$A A B C C$} \\
\hline \multirow[t]{3}{*}{$\left(\mathrm{SOC} / \mathrm{B} /{ }^{\circ} \mathrm{C}\right)$} & & & $\left(\Omega-\mathrm{cm}^{2}\right)$ & $\left(\Omega-\mathrm{cm}^{2}\right.$ & $\overline{\left(\Omega-\mathrm{cm}^{2}\right.}$ & $\left(\Omega-\mathrm{cm}^{2}\right.$ & $\left(\Omega-\mathrm{cm}^{2}\right.$ & $\left(\Omega-\mathrm{cm}^{2}\right)$ & $\overline{\left(\Omega-\mathrm{cm}^{2}\right)}$ & $\left(\Omega-\mathrm{cm}^{2}\right.$ & $\left(\Omega-\mathrm{cm}^{2}\right.$ & $\left(\Omega-\mathrm{cm}^{2}\right)$ & $(\%)$ \\
\hline & & & 21.54 & 23.76 & 24.49 & 24.87 & 25.41 & 25.61 & 25.79 & 26.10 & 26.36 & 26.68 & $24.21 \%$ \\
\hline & & & 0.45 & & 0.70 & 0.56 & 0.53 & 0.74 & 0.62 & 0.71 & 0.78 & 0.83 & $3.01 \%$ \\
\hline & & & & & & & & & & & & & \\
\hline 40540 & 112 & 2G.40540.I112.36.07.11.G.F & 21.58 & 24.13 & 24.18 & 24.84 & 25.22 & 25.15 & 25.51 & 25.79 & 25.78 & 26.07 & $20.78 \%$ \\
\hline 40540 & 120 & 2G.40540.I120.36.06.06.G.F & 20.58 & 22.23 & 23.26 & 23.65 & 24.29 & 24.20 & 24.53 & 24.77 & 24.95 & 25.06 & $21.75 \%$ \\
\hline 40940 & 107 & G2G.40940.1107.36.07.08.G.F & 20.94 & 22.89 & 23.47 & 23.89 & 24.50 & 24.47 & 24.61 & 24.74 & 24.89 & 25.27 & $20.67 \%$ \\
\hline 40940 & 111 & 40.1111.36.07.07.G.F & 21.44 & 23.02 & 24.10 & 24.50 & 25.17 & 25.02 & 25.28 & 25.46 & 25.55 & 25.76 & $20.12 \%$ \\
\hline 80540 & 110 & G2G.80540.I110.36.09.18.G.F & 21.89 & 24.24 & 24.54 & 24.93 & 25.67 & 25.68 & 26.14 & 26.60 & 26.62 & 26.97 & $23.20 \%$ \\
\hline 80540 & 117 & G2G.80540.1117.36.08.15.G.F & 21.60 & 23.24 & 24.14 & 24.57 & 25.16 & 25.12 & 25.49 & 25.84 & 26.10 & 26.10 & $20.80 \%$ \\
\hline 80940 & 106 & G.F & 22.09 & 24.17 & 24.62 & 24.94 & 25.87 & 26.19 & 26.41 & 26.80 & 26.98 & 27.13 & $22.82 \%$ \\
\hline 80940 & 116 & G2G.80940.1116.28.07.13.G.F & 22.33 & 24.82 & 26.15 & 25.03 & 25.69 & 27.14 & 26.19 & & & & $17.28 \%$ \\
\hline 40550 & 103 & G2G.40550.1103.36.08.11.G.F & 20.92 & 23.46 & 24.10 & 24.67 & 24.95 & 25.35 & 25.43 & 25.82 & 26.21 & 26.66 & $27.44 \%$ \\
\hline 40550 & 113 & G.F & 21.78 & 24.36 & 25.08 & 25.82 & 26.17 & 26.36 & 26.55 & 26.93 & 27.22 & 27.62 & $26.79 \%$ \\
\hline 40950 & 104 & G2G.40950.1104.36.09.11.G.F & 21.34 & 23.79 & 24.49 & 24.89 & 25.26 & 25.64 & 25.79 & 26.22 & 26.55 & 27.00 & $26.56 \%$ \\
\hline 40950 & 119 & G2G.40950.I119.36.08.11.G.F & 21.87 & 24.58 & 25.42 & 25.70 & 26.10 & 26.32 & 26.34 & 26.73 & 27.23 & 27.47 & $25.63 \%$ \\
\hline 80550 & 102 & & 21.41 & 23.63 & 24.32 & 24.84 & 25.44 & 25.49 & 25.89 & 26.15 & 26.67 & 27.06 & $26.39 \%$ \\
\hline 80550 & 115 & G2G.80550.1115.36.10.15.G.F & 21.86 & 24.15 & 24.94 & 25.34 & 25.56 & 25.73 & 25.93 & 26.18 & 26.49 & 27.08 & $23.85 \%$ \\
\hline 80950 & 105 & G2G.80950.I105.36.10.21.G.F & 21.31 & 23.85 & 24.50 & 25.22 & 25.89 & 26.18 & 26.50 & 26.94 & 27.28 & 27.63 & $29.63 \%$ \\
\hline 80950 & 108 & G2G.80950.I108.36.11.21.G.F & 21.60 & 23.66 & 24.59 & 25.12 & 25.53 & 25.76 & 26.07 & 26.51 & 26.93 & 27.38 & $26.76 \%$ \\
\hline
\end{tabular}

\subsubsection{Calendar-Life Data}

Table B.6. Calendar-life $\mathrm{C}_{1} / 1$ discharge capacity between $\mathrm{SOC}_{\mathrm{MAX}}$ and $\mathrm{SOC}_{\mathrm{MIN}}$.

\begin{tabular}{|c|c|c|c|c|c|c|c|c|c|c|c|c|c|}
\hline \multicolumn{3}{|c|}{ Core Matrix } & \multirow{2}{*}{\multicolumn{11}{|c|}{$\mathrm{C}_{1} / 1$ Discharge Capacity Between $\mathrm{SOC}_{\mathrm{MAX}}$ and $\mathrm{SOC}_{\mathrm{MIN}}$}} \\
\hline \multicolumn{3}{|c|}{ Calendar-Life Cells } & & & & & & & & & & & \\
\hline \multirow{2}{*}{$\begin{array}{l}\text { Test } \\
\text { Group }\end{array}$} & \multirow[t]{2}{*}{ Cell \# } & \multirow[t]{2}{*}{ ATD Label } & & & & & & & & & & & \\
\hline & & & Char & $4 \mathrm{wk}$ & $8 \mathrm{wk}$ & $12 \mathrm{wk}$ & $16 \mathrm{wk}$ & $20 \mathrm{wk}$ & $24 \mathrm{wk}$ & $28 \mathrm{wk}$ & $32 \mathrm{wk}$ & $36 \mathrm{wk}$ & fade \\
\hline $\mathrm{AABCC}$ & & & & & & & & & & & & & \\
\hline$\left(\mathrm{SOC} / \mathrm{B} /{ }^{\circ} \mathrm{C}\right)$ & & & $(\mathrm{Ah})$ & $(\mathrm{Ah})$ & (Ah) & $(\mathrm{Ah})$ & $(\mathrm{Ah})$ & $(\mathrm{Ah})$ & $(\mathrm{Ah})$ & $(\mathrm{Ah})$ & $(\mathrm{Ah})$ & $(\mathrm{Ah})$ & $(\%)$ \\
\hline & & & 0.372 & 0.344 & 0.339 & 0.336 & 0.319 & 0.334 & 0.332 & 0.330 & & & $11.19 \%$ \\
\hline & & & 0.003 & 0.006 & 0.008 & 0.006 & 0.024 & 0.004 & 0.004 & 0.005 & & & $1.70 \%$ \\
\hline & & & & & & & & & & & & & \\
\hline $80 \mathrm{C} 40$ & 130 & G2G.80C40.1130.28.10.45.L.F & 0.367 & 0.345 & 0.342 & 0.338 & 0.336 & 0.335 & 0.333 & 0.332 & & & $9.64 \%$ \\
\hline $80 \mathrm{C} 40$ & 135 & G2G.80C40.1135.28.09.40.G.F & 0.369 & 0.349 & 0.346 & 0.343 & 0.342 & 0.341 & 0.339 & 0.338 & & & $8.57 \%$ \\
\hline $80 C 50$ & 131 & G2G.80C50.1131.28.12.60.G.F & 0.375 & 0.348 & 0.342 & 0.338 & 0.289 & 0.332 & 0.329 & 0.328 & & & $12.41 \%$ \\
\hline $80 \mathrm{C} 50$ & 132 & G2G.80C50.1132.28.12.59.G.F & 0.376 & 0.351 & 0.345 & 0.340 & 0.287 & 0.335 & 0.334 & 0.333 & & & $11.54 \%$ \\
\hline $80 \mathrm{C} 60$ & 133 & G2G.80C60.1133.28.12.95.G.A & 0.373 & 0.338 & 0.331 & 0.331 & 0.332 & 0.331 & 0.329 & 0.327 & & & $12.32 \%$ \\
\hline $80 \mathrm{C} 60$ & 134 & G2G.80C60.1134.28.13.97.G.L & 0.373 & 0.335 & 0.326 & 0.327 & 0.328 & 0.329 & 0.327 & 0.326 & & & $12.67 \%$ \\
\hline
\end{tabular}

Table B.7. Calendar-life discharge ASI at $\mathrm{SOC}_{\mathrm{MAX}}$ and $30^{\circ} \mathrm{C}$.

\begin{tabular}{|c|c|c|c|c|c|c|c|c|c|c|c|c|c|}
\hline \multicolumn{3}{|c|}{ Core Matrix } & \multirow{2}{*}{\multicolumn{11}{|c|}{$30^{\circ} \mathrm{C}$ Discharge $\mathrm{ASI}$ at $\mathrm{SOC}_{\mathrm{MAX}}$}} \\
\hline \multicolumn{3}{|c|}{ Calendar-Life Cells } & & & & & & & & & & & \\
\hline \multirow{2}{*}{$\begin{array}{l}\text { Test } \\
\text { Group }\end{array}$} & \multirow[t]{2}{*}{ Cell \# } & \multirow[t]{2}{*}{ ATD Label } & & & & & & & & & & & \\
\hline & & & Char & $4 \mathrm{wk}$ & $8 \mathrm{wk}$ & $12 \mathrm{wk}$ & $16 \mathrm{wk}$ & $20 \mathrm{wk}$ & $24 \mathrm{wk}$ & $28 \mathrm{wk}$ & $32 \mathrm{wk}$ & $36 \mathrm{wk}$ & fade \\
\hline $\mathrm{AABCC}$ & & & & & & & & & & & & & \\
\hline$\left(\mathrm{SOC} / \mathrm{B} /{ }^{\circ} \mathrm{C}\right)$ & & & $\left(\Omega-\mathrm{cm}^{2}\right)$ & $\left(\Omega-\mathrm{cm}^{2}\right)$ & $\left(\Omega-\mathrm{cm}^{2}\right.$ & $\left(\Omega-\mathrm{cm}^{2}\right)$ & $\left(\Omega-\mathrm{cm}^{2}\right.$ & $\overline{\left(\Omega-\mathrm{cm}^{2}\right)}$ & $\overline{\left(\Omega-\mathrm{cm}^{2}\right)}$ & $\left(\Omega-\mathrm{cm}^{2}\right)$ & $\left(\Omega-\mathrm{cm}^{2}\right)$ & $\left(\Omega-\mathrm{cm}^{2}\right)$ & $(\%)$ \\
\hline & & & 28.13 & 35.16 & 37.71 & 41.24 & 42.77 & 44.37 & 46.10 & 46.56 & & & $\overline{66.12 \%}$ \\
\hline & & & 1.82 & 3.14 & 4.00 & 4.47 & 4.74 & 5.04 & 5.84 & 6.09 & & & $24.60 \%$ \\
\hline $80 \mathrm{C40}$ & 130 & 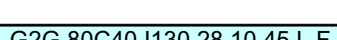 & 2170 & 36.27 & 3827 & 1151 & 1277 & 1396 & 1173 & 1589 & & & $11760 \%$ \\
\hline $80 \mathrm{C} 40$ & $\frac{135}{135}$ & G2G.80C40.1135.28.09.40.G.F & 28.18 & $\frac{00.01}{31.39}$ & $\frac{0.21}{32.82}$ & $\begin{array}{l}41.54 \\
35.44\end{array}$ & $\frac{42.11}{36.56}$ & $\begin{array}{l}37.00 \\
37.61\end{array}$ & $\begin{array}{l}44.13 \\
38.49\end{array}$ & $\begin{array}{l}45.88 \\
39.56\end{array}$ & & & $\frac{44.16 \%}{40.38 \%}$ \\
\hline $80 C 50$ & 131 & G2G.80C50.1131.28.12.60.G.F & 26.86 & 32.80 & 34.94 & 38.49 & 39.91 & 41.78 & 43.38 & 42.89 & & & $59.68 \%$ \\
\hline $80 C 50$ & 132 & G2G.80C50.1132.28.12.59.G.F & 27.05 & 33.18 & 35.52 & 39.09 & 40.74 & 42.33 & 43.79 & 43.10 & & & $59.35 \%$ \\
\hline $80 \mathrm{C} 60$ & 133 & G2G.80C60.1133.28.12.95.G.A & 27.88 & 39.04 & 42.47 & 46.51 & 48.52 & 50.61 & 53.39 & 54.40 & & & $95.15 \%$ \\
\hline $80 \mathrm{C} 60$ & 134 & G2G.80C60.1134.28.13.97.G.L & 27.13 & 38.18 & 42.25 & 46.37 & 48.10 & 49.96 & 52.81 & 53.55 & & & $97.39 \%$ \\
\hline
\end{tabular}


Table B.8. Calendar-life temperature-compensated discharge ASI at $\mathrm{SOC}_{\mathrm{MAX}}$ and $30^{\circ} \mathrm{C}$.

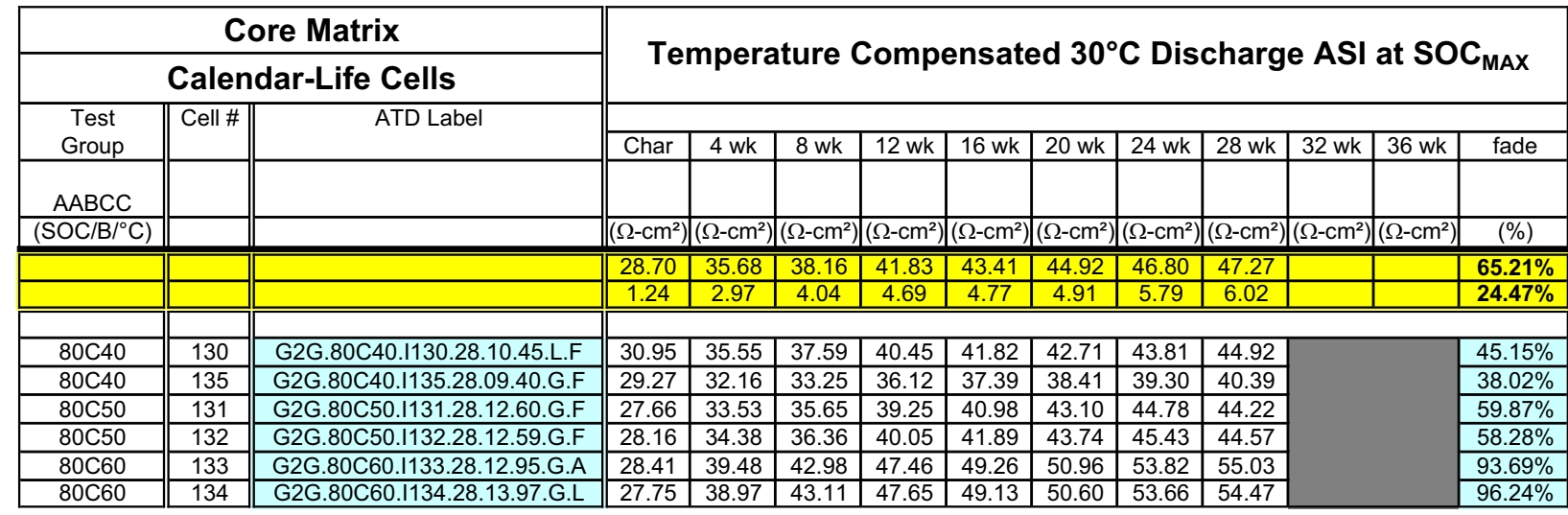

Table B.9. Calendar-life discharge ASI at $\mathrm{SOC}_{\mathrm{MIN}}$ and $30^{\circ} \mathrm{C}$.

\begin{tabular}{|c|c|c|c|c|c|c|c|c|c|c|c|c|c|}
\hline & & re Matrix & \multirow{2}{*}{\multicolumn{11}{|c|}{$30^{\circ} \mathrm{C}$ Discharge ASI at $\mathrm{SOC}_{\mathrm{MIN}}$}} \\
\hline \multicolumn{3}{|c|}{ Calendar-Life Cells } & & & & & & & & & & & \\
\hline Test & Cell \# & ATD Label & & & & & & & & & & & \\
\hline Group & & & Char & $4 \mathrm{wk}$ & $8 \mathrm{wk}$ & $12 \mathrm{wk}$ & $16 \mathrm{wk}$ & $20 \mathrm{wk}$ & $24 \mathrm{wk}$ & $28 \mathrm{wk}$ & $32 \mathrm{wk}$ & $36 \mathrm{wk}$ & fade \\
\hline $\mathrm{AABCC}$ & & & & & & & & & & & & & \\
\hline$\left(\mathrm{SOC} / \mathrm{B} /{ }^{\circ} \mathrm{C}\right)$ & & & $\left(\Omega-\mathrm{cm}^{2}\right.$ & $\left(\Omega-\mathrm{cm}^{2}\right.$ & $\left(\Omega-\mathrm{cm}^{2}\right)$ & $\left(\Omega-\mathrm{cm}^{2}\right)$ & $\left(\Omega-\mathrm{cm}^{2}\right.$ & $\left(\Omega-\mathrm{cm}^{2}\right.$ & $\left(\Omega-\mathrm{cm}^{2}\right)$ & $\left(\Omega-\mathrm{cm}^{2}\right)$ & $\left(\Omega-\mathrm{cm}^{2}\right.$ & $\left(\Omega-\mathrm{cm}^{2}\right)$ & $(\%)$ \\
\hline & & & 24.29 & 31.67 & 33.86 & 34.89 & 36.05 & 36.93 & 37.63 & $\begin{array}{ll}38.48 \\
\end{array}$ & & & $58.78 \%$ \\
\hline & & & 1.13 & 2.26 & 2.81 & 2.99 & 3.35 & 3.74 & 3.91 & 4.15 & & & $19.18 \%$ \\
\hline $80 \mathrm{C} 40$ & 130 & $G 2 G 80 C 401130281045 I F$ & $26: 12$ & 3205 & 2381 & 3172 & $3562+3>+3$ & 36.15 & 3681 & 2725 & & & $4099 \%$ \\
\hline $80 C 40$ & $\frac{100}{135}$ & G2G.80C40.1135.28.09.40.G.F & $\frac{24.42}{24.44}$ & 29.06 & $\frac{30.01}{30.49}$ & $\frac{34.12}{31.34}$ & $\frac{0.02}{32.11}$ & $\frac{0.40}{32.93}$ & 33.43 & $\frac{31.20}{33.87}$ & & & $\frac{40.99 \%}{38.59 \%}$ \\
\hline $80 \mathrm{C50}$ & 131 & G2G.80C50.1131.28.12.60.G.F & 23.31 & 29.91 & 31.92 & 32.85 & 33.78 & 34.28 & 35.05 & 36.09 & & & $54.82 \%$ \\
\hline $80 \mathrm{C50}$ & 132 & G2G.80C50.1132.28.12.59.G.F & 23.61 & 30.46 & 32.58 & 33.51 & 34.61 & 34.88 & 35.54 & 36.43 & & & $54.26 \%$ \\
\hline $80 \mathrm{C} 60$ & 133 & G2G.80C60.1133.28.12.95.G.A & 24.30 & 34.66 & 37.63 & 38.95 & 40.66 & 41.95 & 42.94 & 44.17 & & & $81.80 \%$ \\
\hline $80 \mathrm{C} 60$ & 134 & G2G.80C60.1134.28.13.97.G.L & 23.64 & 33.89 & 36.75 & 37.99 & 39.50 & 41.10 & 42.01 & 43.08 & & & $82.21 \%$ \\
\hline
\end{tabular}

Table B.10. Calendar-life temperature-compensated discharge ASI at $\mathrm{SOC}_{\mathrm{MIN}}$ and $30^{\circ} \mathrm{C}$.

\begin{tabular}{|c|c|c|c|c|c|c|c|c|c|c|c|c|c|}
\hline & & pre Matrix & \multirow{2}{*}{\multicolumn{11}{|c|}{ Temperature Compensated $30^{\circ} \mathrm{C}$ Discharge ASI at $\mathrm{SOC}_{\mathrm{MIN}}$}} \\
\hline \multicolumn{3}{|c|}{ Calendar-Life Cells } & & & & & & & & & & & \\
\hline \multirow{2}{*}{$\begin{array}{l}\text { Test } \\
\text { Group }\end{array}$} & \multirow[t]{2}{*}{ Cell \# } & \multirow{2}{*}{ ATD Label } & & & & & & & & & & & \\
\hline & & & Char & $4 \mathrm{wk}$ & $8 \mathrm{wk}$ & $12 \mathrm{wk}$ & $16 \mathrm{wk}$ & $20 \mathrm{wk}$ & $24 \mathrm{wk}$ & $28 \mathrm{wk}$ & $32 \mathrm{wk}$ & $36 \mathrm{wk}$ & fade \\
\hline $\mathrm{AABCC}$ & & & & & & & & & & & & & \\
\hline$\left(\mathrm{SOC} / \mathrm{B} /{ }^{\circ} \mathrm{C}\right)$ & & & $\left(\Omega-\mathrm{cm}^{2}\right)$ & $\left(\Omega-\mathrm{cm}^{2}\right)$ & $\left(\Omega-\mathrm{cm}^{2}\right)$ & $\left(\Omega-\mathrm{cm}^{2}\right)$ & $\left(\Omega-\mathrm{cm}^{2}\right)$ & $\left(\Omega-\mathrm{cm}^{2}\right)$ & $\left(\Omega-\mathrm{cm}^{2}\right)$ & $\left(\Omega-\mathrm{cm}^{2}\right.$ & $\left(\Omega-\mathrm{cm}^{2}\right)$ & $\left(\Omega-\mathrm{cm}^{2}\right)$ & $(\%)$ \\
\hline & & & 24.66 & 32.26 & 34.21 & 35.48 & 36.52 & 37.35 & 38.28 & 39.18 & & & $59.18 \%$ \\
\hline & & & 0.77 & 2.13 & 2.86 & 3.23 & 3.35 & 3.63 & 3.86 & 4.17 & & & $19.16 \%$ \\
\hline & & & & & & & & & & & & & \\
\hline $80 \mathrm{C} 40$ & 130 & G2G.80C40.I130.28.10.45.L.F & 26.02 & 31.22 & 32.76 & 33.63 & 34.63 & 35.00 & 35.79 & 36.20 & & & $39.13 \%$ \\
\hline $80 \mathrm{C} 40$ & 135 & G2G.80C40.1135.28.09.40.G.F & 24.96 & 29.97 & 31.11 & 32.07 & 32.93 & 33.79 & 34.40 & 34.76 & & & $39.24 \%$ \\
\hline $80 \mathrm{C} 50$ & 131 & G2G.80C50.1131.28.12.60.G.F & 23.84 & 30.80 & 32.60 & 33.59 & 34.62 & 35.33 & 36.27 & 37.45 & & & $57.09 \%$ \\
\hline $80 C 50$ & 132 & G2G.80C50.1132.28.12.59.G.F & 24.33 & 31.77 & 33.22 & 34.59 & 35.56 & 36.10 & 36.94 & 37.98 & & & $56.07 \%$ \\
\hline $80 \mathrm{C} 60$ & 133 & G2G.80C60.1133.28.12.95.G.A & 24.67 & 35.16 & 38.02 & 39.88 & 41.11 & 42.25 & 43.51 & 44.74 & & & $81.32 \%$ \\
\hline $80 \mathrm{C} 60$ & 134 & G2G.80C60.1134.28.13.97.G.L & 24.14 & 34.62 & 37.54 & \begin{tabular}{|l|}
39.13 \\
\end{tabular} & 40.28 & 41.61 & 42.77 & 43.99 & & & $82.24 \%$ \\
\hline
\end{tabular}




\section{B.3 Supplemental-Life Test Data}

\subsubsection{Path Dependence Data}

Table B.11. Path dependence $\mathrm{C}_{1} / 1$ discharge capacity between $\mathrm{SOC}_{\mathrm{MAX}}$ and $\mathrm{SOC}_{\mathrm{MIN}}$.

\begin{tabular}{|c|c|c|c|c|c|c|c|c|c|c|c|c|c|}
\hline \multirow{2}{*}{\multicolumn{3}{|c|}{$\begin{array}{c}\text { Supplemental Matrix } \\
\text { Path Dependence Cells }\end{array}$}} & \multirow{2}{*}{\multicolumn{11}{|c|}{$\mathrm{C}_{1} / 1$ Discharge Capacity Between $\mathrm{SOC}_{\mathrm{MAX}}$ and $\mathrm{SOC}_{\mathrm{MIN}}$}} \\
\hline & & & & & & & & & & & & & \\
\hline \multirow{2}{*}{$\begin{array}{c}\text { Test } \\
\text { Group } \\
\end{array}$} & \multirow[t]{2}{*}{ Cell \# } & \multirow[t]{2}{*}{ ATD Label } & \multirow[b]{2}{*}{ Char } & \multirow[b]{2}{*}{$4 \mathrm{wk}$} & \multirow[b]{2}{*}{$8 \mathrm{wk}$} & \multirow[b]{2}{*}{$12 \mathrm{wk}$} & \multirow[b]{2}{*}{$16 \mathrm{wk}$} & \multirow[b]{2}{*}{$20 \mathrm{wk}$} & \multirow[b]{2}{*}{$24 \mathrm{wk}$} & \multirow[b]{2}{*}{$28 \mathrm{wk}$} & \multirow[b]{2}{*}{$32 \mathrm{wk}$} & \multirow[b]{2}{*}{$36 \mathrm{wk}$} & \multirow[b]{2}{*}{ fade } \\
\hline & & & & & & & & & & & & & \\
\hline \multicolumn{14}{|l|}{$\mathrm{AABCC}$} \\
\hline \multirow[t]{3}{*}{$\left(\mathrm{SOC} / \mathrm{B} /{ }^{\circ} \mathrm{C}\right)$} & & & (Ah) & (Ah) & (Ah) & (Ah) & $(\mathrm{Ah})$ & $(\mathrm{Ah})$ & (Ah) & (Ah) & (Ah) & (Ah) & $(\%)$ \\
\hline & & & 0.359 & 0.338 & 0.336 & 0.333 & 0.332 & 0.333 & 0.331 & 0.330 & & & $8.16 \%$ \\
\hline & & & 0.006 & 0.010 & 0.011 & 0.011 & 0.010 & 0.009 & 0.009 & 0.010 & & & $1.69 \%$ \\
\hline $40 \mathrm{C} 540$ & 101 & G2G.40C540.1101.28.09.12.G.F & 0.357 & 0.331 & 0.329 & 0.327 & 0.326 & 0.327 & 0.326 & 0.325 & & & $8.94 \%$ \\
\hline $40 \mathrm{C} 540$ & 121 & G2G.40C540.I121.28.06.23.G.F & 0.365 & 0.350 & 0.348 & 0.345 & 0.344 & 0.342 & 0.342 & 0.341 & & & $6.42 \%$ \\
\hline $80 C 950$ & 109 & G2G.80C950.I109.28.09.19.G.L & 0.354 & 0.328 & 0.325 & 0.323 & 0.324 & 0.328 & 0.326 & 0.322 & & & $8.92 \%$ \\
\hline $80 \mathrm{C} 950$ & 118 & G2G.80C950.I118.28.09.17.G.A & 0.349 & 0.326 & 0.321 & 0.317 & 0.317 & 0.324 & 0.320 & 0.317 & & & $9.19 \%$ \\
\hline $405 \mathrm{C} 40$ & 114 & G2G.405C40.I114.28.08.10.G.F & 0.358 & 0.337 & 0.336 & 0.335 & 0.334 & 0.333 & 0.332 & 0.330 & & & $7.82 \%$ \\
\hline $405 \mathrm{C} 40$ & 125 & G2G.405C40.I125.28.05.04.G.F & 0.365 & 0.353 & 0.351 & 0.350 & 0.349 & 0.349 & 0.348 & 0.347 & & & $5.03 \%$ \\
\hline $809 C 50$ & 136 & G2G.809C50.I136.28.10.96.G.L & 0.366 & 0.344 & 0.340 & 0.334 & 0.332 & 0.331 & 0.329 & 0.328 & & & $10.26 \%$ \\
\hline $809 C 50$ & 137 & \begin{tabular}{|l|} 
G2G.809C50.1137.28.09.91.G.A \\
\end{tabular} & 0.360 & 0.337 & 0.334 & 0.330 & 0.329 & 0.329 & 0.328 & 0.329 & & & $8.73 \%$ \\
\hline
\end{tabular}

Table B.12. Path dependence discharge ASI at $\mathrm{SOC}_{\mathrm{MAX}}$ and $30^{\circ} \mathrm{C}$.

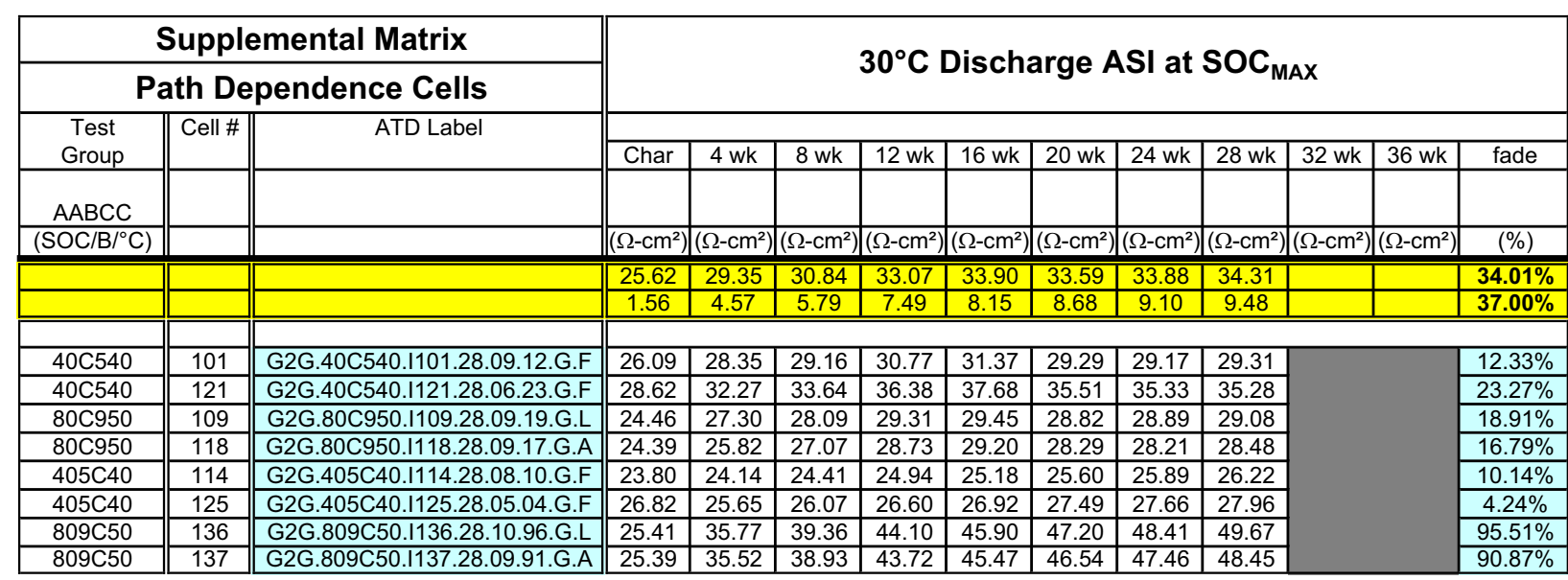

Table B.13. Path dependence temperature-compensated discharge ASI at $\mathrm{SOC}_{\mathrm{MAX}}$ and $30^{\circ} \mathrm{C}$.

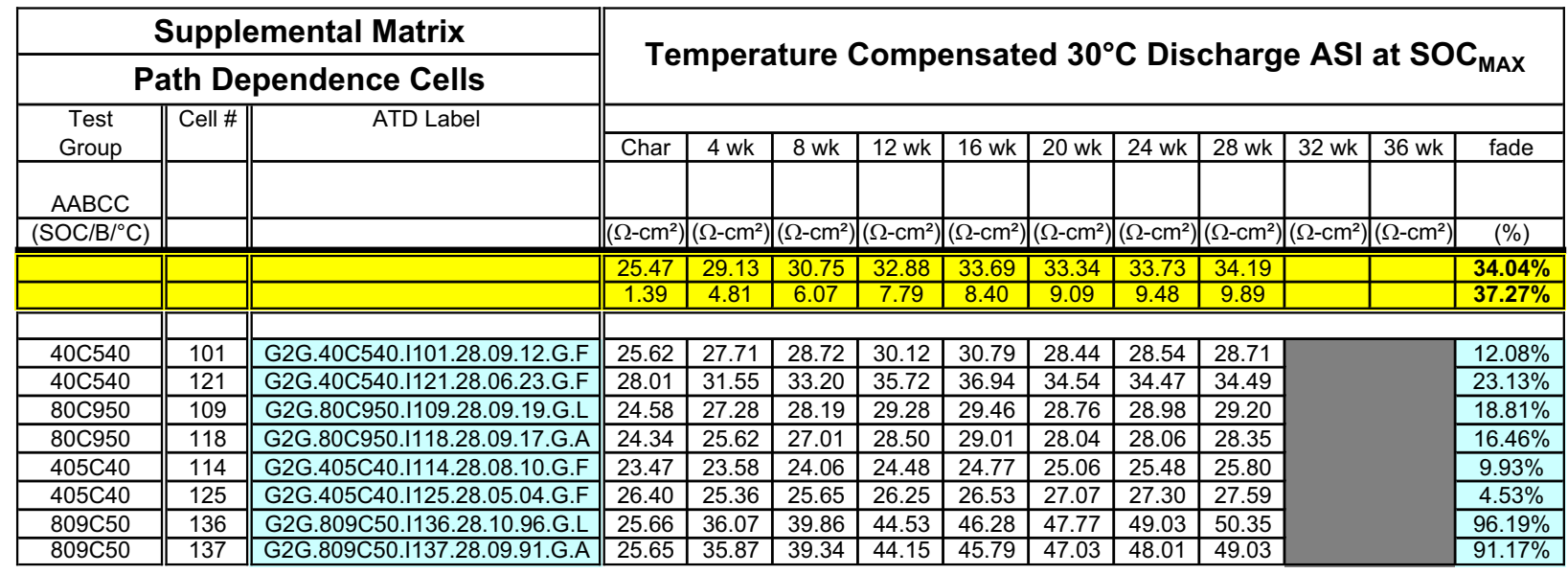


Table B.14. Path dependence discharge ASI at $\mathrm{SOC}_{\mathrm{MIN}}$ and $30^{\circ} \mathrm{C}$.

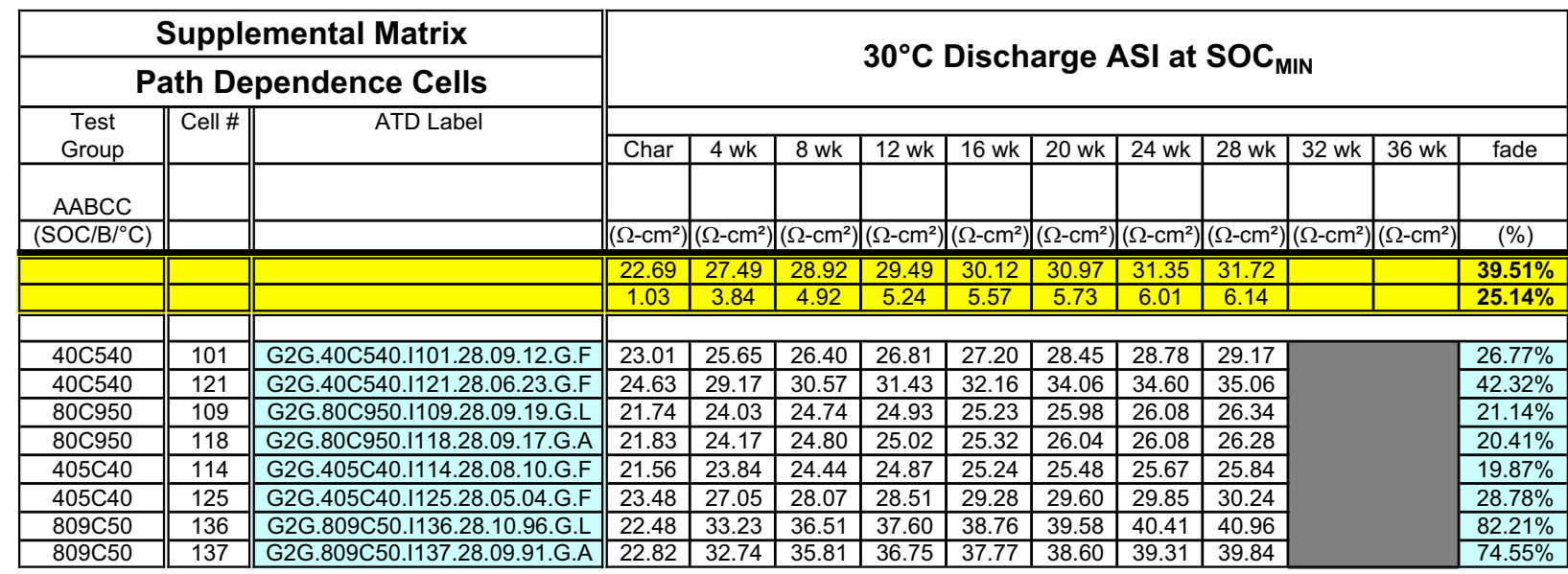

Table B.15. Path dependence temperature-compensated discharge ASI at $\mathrm{SOC}_{\mathrm{MIN}}$ and $30^{\circ} \mathrm{C}$.

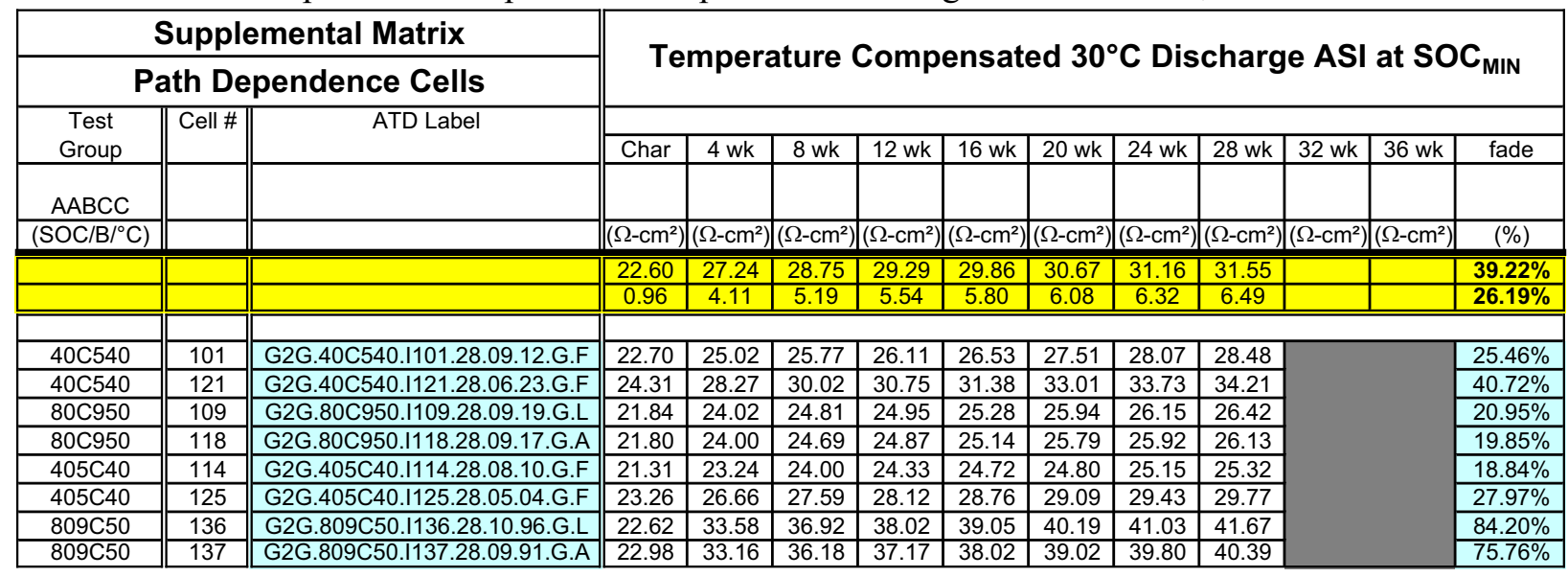

\subsubsection{RPT Study Data}

The RPT Study cell group was based on full $\mathrm{C}_{1} / 1$ and L-HPPC test every four weeks. Consequently, no temperature compensation was performed on the data (no L-HPPC at test temperature), but the available power at $300 \mathrm{Wh}$ was calculated and scaled by the battery size factor (488, see Section 2.1 ).

Table B.16. RPT study $\mathrm{C}_{1} / 1$ discharge capacity between full charge and discharge.

\begin{tabular}{|c|c|c|c|c|c|c|c|c|c|c|c|c|c|}
\hline \multirow{2}{*}{\multicolumn{3}{|c|}{$\begin{array}{c}\text { Supplemental Matrix } \\
\text { Path Dependence Cells }\end{array}$}} & \multirow{2}{*}{\multicolumn{11}{|c|}{ Full $C_{1} / 1$ Discharge Capacity }} \\
\hline & & & & & & & & & & & & & \\
\hline \multirow{2}{*}{$\begin{array}{c}\text { Test } \\
\text { Group }\end{array}$} & \multirow[t]{2}{*}{ Cell \# } & \multirow[t]{2}{*}{ ATD Label } & & & & & & & & & & & \\
\hline & & & Char & $4 \mathrm{wk}$ & $8 \mathrm{wk}$ & $12 \mathrm{wk}$ & $16 \mathrm{wk}$ & $20 \mathrm{wk}$ & $24 \mathrm{wk}$ & $28 \mathrm{wk}$ & $32 \mathrm{wk}$ & $36 \mathrm{wk}$ & fade \\
\hline$A A B C C$ & & & & & & & & & & & & & \\
\hline$\left(\mathrm{SOC} / \mathrm{B} /{ }^{\circ} \mathrm{C}\right)$ & & & (Ah) & (Ah) & $(\mathrm{Ah})$ & $(\mathrm{Ah})$ & (Ah) & (Ah) & (Ah) & (Ah) & (Ah) & (Ah) & $(\%)$ \\
\hline & & & 0.908 & 0.867 & 0.852 & 0.841 & 0.831 & 0.829 & 0.870 & 0.864 & & & $9.39 \%$ \\
\hline & & & 0.043 & 0.048 & 0.056 & 0.062 & 0.066 & 0.068 & 0.006 & 0.006 & & & $3.68 \%$ \\
\hline 40540 & 127 & G2G.40540.1127.28.07.28.G.L & 0.921 & 0.890 & 0.887 & 0.880 & 0.875 & 0.870 & 0.866 & 0.860 & & & $6.58 \%$ \\
\hline 40540 & 128 & G2G.40540.I128.28.06.27.G.A & 0.924 & 0.896 & 0.893 & 0.887 & 0.882 & 0.881 & 0.874 & 0.868 & & & $6.00 \%$ \\
\hline 80950 & 123 & G2G.80950.I123.20.13.95.G.A & 0.845 & 0.795 & 0.771 & 0.752 & 0.738 & 0.731 & & & & & $13.48 \%$ \\
\hline 80950 & 138 & G2G.80950.I138.20.12.88.G.L & 0.942 & 0.886 & 0.857 & 0.846 & 0.829 & 0.833 & & & & & $11.51 \%$ \\
\hline
\end{tabular}


Table B.17. RPT study interpolated discharge ASI at $\mathrm{SOC}_{\mathrm{MAX}}$ and $30^{\circ} \mathrm{C}$.

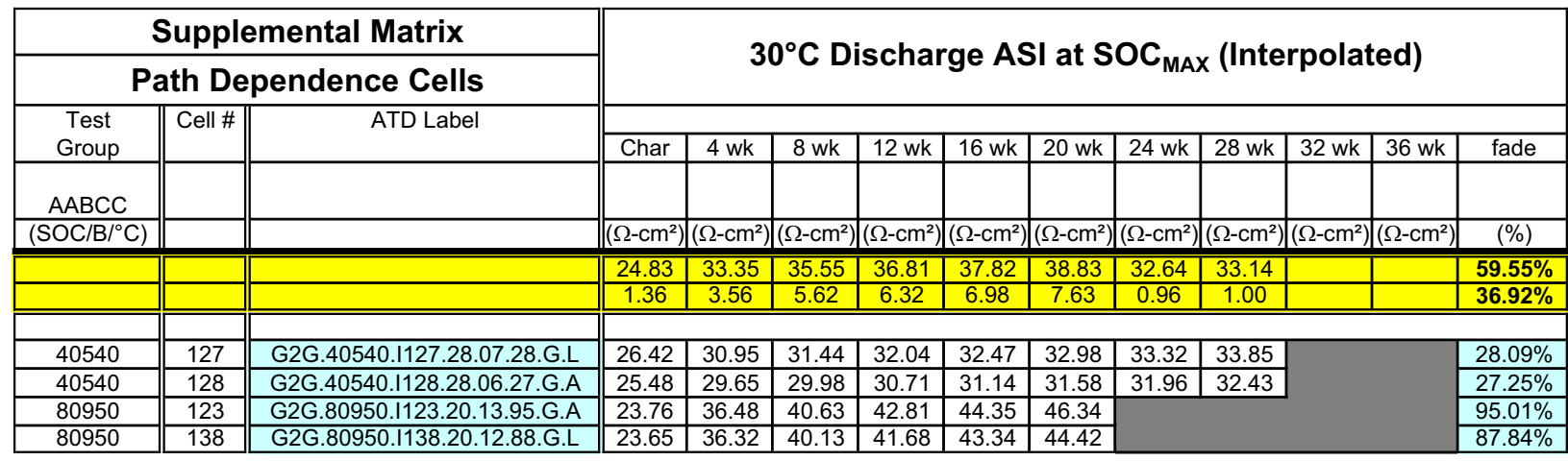

Table B.18. RPT study interpolated discharge ASI at $\mathrm{SOC}_{\mathrm{MIN}}$ and $30^{\circ} \mathrm{C}$.

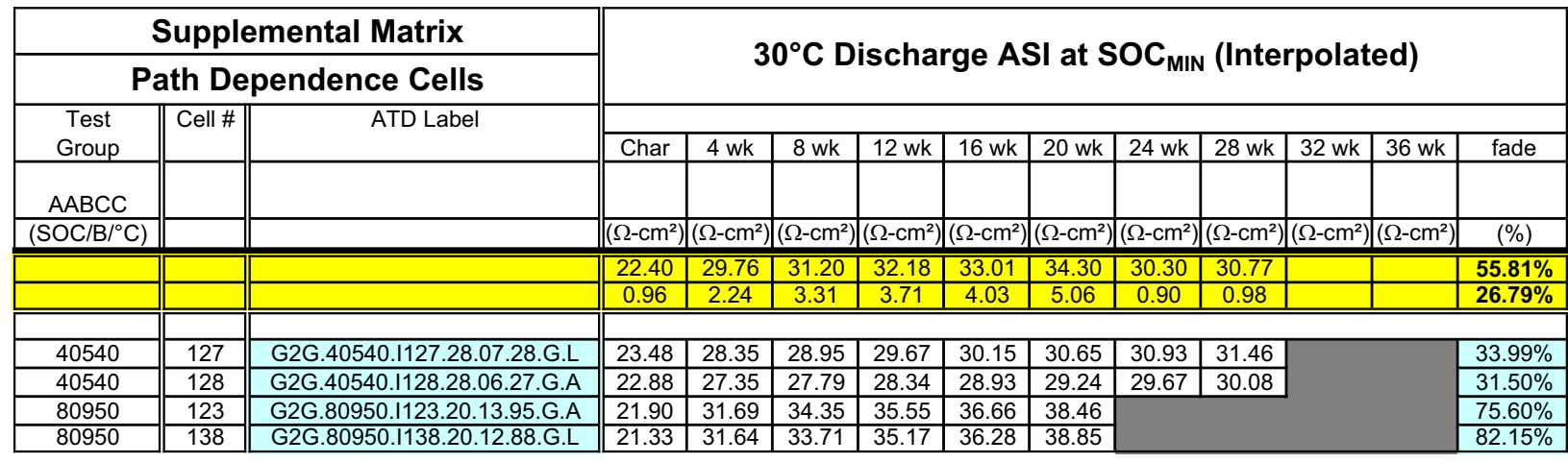

Table B.20. RPT study available power at $300 \mathrm{Wh}$.

\begin{tabular}{|c|c|c|c|c|c|c|c|c|c|c|c|c|c|}
\hline \multirow{2}{*}{\multicolumn{3}{|c|}{$\begin{array}{c}\text { Supplemental Matrix } \\
\text { Path Dependence Cells }\end{array}$}} & \multirow{2}{*}{\multicolumn{11}{|c|}{ Available Power at $300 \mathrm{Wh}$}} \\
\hline & & & & & & & & & & & & & \\
\hline \multirow{2}{*}{$\begin{array}{c}\text { Test } \\
\text { Group } \\
\end{array}$} & \multirow[t]{2}{*}{ Cell \# } & \multirow[t]{2}{*}{ ATD Label } & & & & & & & & & & & \\
\hline & & & Char & $4 \mathrm{wk}$ & $8 w k$ & $12 \mathrm{wk}$ & $16 \mathrm{wk}$ & $20 \mathrm{wk}$ & $24 \mathrm{wk}$ & $28 \mathrm{wk}$ & $32 \mathrm{wk}$ & $36 \mathrm{wk}$ & fade \\
\hline AABCC & & & & & & & & & & & & & \\
\hline$\left(\mathrm{SOC} / \mathrm{B} /{ }^{\circ} \mathrm{C}\right)$ & & & $(\mathrm{kW})$ & $(\mathrm{kW})$ & $(\mathrm{kW})$ & $(\mathrm{kW})$ & $(\mathrm{kW})$ & $(\mathrm{kW})$ & $(\mathrm{kW})$ & $(\mathrm{kW})$ & $(\mathrm{kW})$ & $(\mathrm{kW})$ & $(\%)$ \\
\hline & & & 32.55 & 24.64 & 23.48 & 22.75 & 22.13 & 21.43 & 24.51 & 24.11 & & & $35.00 \%$ \\
\hline & & & 1.07 & 2.39 & 3.18 & 3.41 & 3.58 & 3.97 & 0.59 & 0.63 & & & $12.82 \%$ \\
\hline & & & & & & & & & & & & & \\
\hline$\frac{40540}{40540}$ & $\frac{127}{128}$ & $\frac{\text { G2G.40540.I127.28.07.28.G.L }}{\text { G2G.40540.1128.28.06.27.G.A }}$ & $\frac{31.47}{31.91}$ & $\frac{26.26}{27.12}$ & $\frac{25.88}{26.55}$ & $\frac{25.28}{26.09}$ & $\frac{24.76}{2565}$ & $\frac{24.27}{25.40}$ & $\frac{24.09}{24.92}$ & $\frac{23.67}{24.56}$ & & & $\frac{24.78 \%}{23.05 \%}$ \\
\hline 80950 & 123 & G2G.80950.I123.20.13.95.G.A & 33.01 & 22.55 & 20.52 & 19.56 & 18.77 & 17.80 & & & & & $46.06 \%$ \\
\hline 80950 & 138 & G2G.80950.1138.20.12.88.G.L & 33.83 & 22.64 & 20.96 & 20.06 & 19.34 & 18.23 & & & & & $46.12 \%$ \\
\hline
\end{tabular}

